College of William \& Mary Law School William \& Mary Law School Scholarship Repository

1987

\title{
Averting Government by Consent Decree: Constitutional Limits on the Enforcement of Settlements with the Federal Government
}

Jeremy A. Rabkin

Neal Devins

William ઐ Mary Law School, nedevi@wm.edu

\section{Repository Citation}

Rabkin, Jeremy A. and Devins, Neal, "Averting Government by Consent Decree: Constitutional Limits on the Enforcement of Settlements with the Federal Government" (1987). Faculty Publications. 414.

https://scholarship.law.wm.edu/facpubs/414 


\title{
Averting Government by Consent Decree: Constitutional Limits on the Enforcement of Settlements with the Federal Government
}

\author{
Jeremy A. Rabkin* \\ Neal E. Devins**
}

\section{INTRODUCTION}

The number of suits against federal agencies and departments has increased dramatically in recent decades. ${ }^{1}$ Judicial initiatives and congressional enactments in the late 1960s and early 1970 s significantly weakened the traditional obstacles to suits against the government (such as standing barriers, sovereign immunity defenses, and nonreviewability doctrines) and have exposed an increasingly wide range of governmental decisions to legal challenge. ${ }^{2}$ Moreover, the proliferation of public interest law organizations since the early $1970 \mathrm{~s}$ has meant that federal agencies are frequent defendants in suits involving "questions of important public policy."

Like other defendants, the federal government frequently agrees to settle suits against it with consent agreements or consent decrees. This

- Assistant Professor, Department of Government, Cornell University. B.A., Cornell University, 1974; Ph.D., Harvard University, 1983.

** Assistant Professor, College of William and Mary, Marshall-Wythe School of Law. A.B., Georgetown University, 1978; J.D., Vanderbilt Law School, 1982. The authors would like to express their appreciation to those attorneys who shared their court briefs and thoughts with them. Special thanks are owed to Jim Bradke, Judith Ledbetter, Alfred Aman, and Robert Summers, for their thoughtful comments.

1. In 1960, for example, federal appellate courts received 737 appeals from federal administrative agency decisions. 1963 ADMIN. OfF, OF UNITED States Courts ANN. REP, 188. The corresponding figure in 1983 was 3,069. 1983 Admin. OFF. OF UNited States Courts ANN. REP. 101. In 1969, federal courts of appeals received 1,472 appeals from the district courts in suits of all kinds against the federal government. 1973 ADMIN. OFF. OF UNITED States Courts AnN. REP. 104. The corresponding figure in 1983 was 4,856. 1983 ADMin. OfF. of Untred States Courts Ann. Rep. 103.

2. For an overview of the trends, see Stewart, The Reformation of American Administrative Law, 88 HARV. L. REv. 1667 (1975).

3. Two commentators have defined public interest practice as the activity of a "nonprofit, tax-exempt group that devotes a large share of its program to providing legal representation to otherwise unrepresented interests in ... proceedings involving questions of important public policy." D. Clovis \& N. Aron, Survey of Public Interest Law Centers: NARRATIVE REPORT $1 \mathrm{n} . * *$ (1980). 
practice saves time and effort for Justice Department lawyers, of course, and may forestall more damaging or burdensome judicial resolutions. But in suits involving "questions of important public policy," the practice has obvious dangers. It allows one administration to commit its successors to policies they might not otherwise have chosen. And it presents the risk that major policy decisions will be fixed in secret negotiations with small groups of private plaintiffs rather than through the more open and accountable procedures of ordinary executive decisionmaking.

Before the 1980 election, these dangers may have seemed hypothetical. But that presidential election produced a sharp change in the political and policy perspective of the executive branch-undoubtedly the sharpest change since the early 1970 s and, in the view of most public interest law organizations, surely the most adverse. ${ }^{4}$ Consent decrees negotiated by the Carter Administration naturally posed difficulties in a number of areas for Reagan appointees. And public interest law organizations charged the new administration with failing to uphold the terms of some of these earlier agreements. Federal courts have thus faced a novel and vexing question in the last few years: Must consent decrees be enforced when they constrain the policy prerogatives of a new administration?

The range of policy contexts in which this question has come before appellate courts illustrates its scope and importance. In recent years, federal courts of appeal have considered the question in such diverse federal policy fields as environmental regulation, ${ }^{5}$ civil rights enforcement, ${ }^{6}$ federal mortgage subsidy programs, ${ }^{7}$ and the national security efforts of the Federal Bureau of Investigation ("FBI"). 8 Moreover, the agreements involved were not minor or peripheral, but controlled such fundamental executive concerns as the content of presidential recom-

4. The results of a 1983 survey of public interest lawyers illustrate the ideological distance between the public interest law movement and the Reagan Administration. See Lichter \& Rothman, What Interests the Public and What Interests the Public Interests, PuB. OpInion, Apr.-May 1983 , at 44 . The survey found that only $3 \%$ of public interest lawyers had voted for Gerald Ford in 1976 and that only $2 \%$ voted for Ronald Reagan in 1980. Id. at 46 . When asked whether they "approved" of the activities of particular public figures, the survey participants responded most favorably toward Ralph Nader and Senator Edward Kennedy (each obtained approval from $93 \%$ of the respondents). Id at $47-48$. Whereas $34 \%$ indicated approval of Fidel Castro, only $5 \%$ reported approval of President Reagan. Id. at 48.

5. National Audubon Soc'y v. Watt, 678 F.2d 299 (D.C. Cir. 1982); see notes 232-239 infra and accompanying text.

6. Women's Equity Action League v. Bell, 743 F.2d 42 (D.C. Cir. 1984). This case was a consolidation of two cases, Women's Equily Action League ("WEAL") and Adams v. Bell, both of which concerned the same amended consent agreement. Although WEAL is noted first in this discussion, Adams is the earlier case, and therefore we will use the case name Adams throughout this article to refer to all phases of this complex litigation. See notes 213-231 infra and accompanying text.

7. Ferrell v. Pierce, 743 F.2d 454 (7th Cir. 1984); see notes 240-247 infra and accompanying text.

8. Alliance to End Repression v. City of Chicago, 742 F.2d 1007 (7th Cir. 1984); see notes 206-211 infra and accompanying text. 
mendations to Congress, ${ }^{9}$ the details of regulatory standards, ${ }^{10}$ and the timing and methods of ongoing executive enforcement operations. ${ }^{11}$

In some of these cases, courts interpreted consent decrees of a previous administration to accommodate a new administration's concern for policy flexibility and to ease evident qualms about excessive judicial intrusion into internal executive affairs. But no appellate decision on the subject has yet offered a clear ruling on the underlying constitutional issues raised by such broad ranging consent agreements. For the most part, the courts have relegated the entire responsibility for avoiding burdensome consent agreements to the executive branch. The Supreme Court's 1986 decision in Local No. 93, International Association of Firefighters $v$. City of Cleveland ${ }^{12}$ seems to endorse this complacent approach. The Court held that district courts may even enforce provisions in consent decrees that they could not properly order on their own authority. ${ }^{13}$

The problem with this approach is that executive officials often face powerful incentives to achieve quick settlement of disputes. Thus, they are not always reliable guardians of their own or their successors' longterm policy discretion. Not until March 1986 did the Attorney General issue guidelines to Justice Department litigators prohibiting them from agreeing to constraints on executive or administrative discretion beyond what courts could order on their own authority. ${ }^{14}$ The guidelines single out a few aspects of executive discretion as properly exempt from judicial control and hence not properly constrained by consent agreements. ${ }^{15}$ The brief memorandum presenting these guidelines

9. United States v. Board of Educ. of Chicago, 744 F.2d 1300 (7th Cir. 1984), cerl. denied, 467 U.S. 1116 (1985); see National Audubon Soc'y, 678 F.2d at 299; notes 192-205 infra and accompanying text.

I0. Ferrell, 743 F.2d at 454; Citizens for a Better Env't v. Gorsuch, 718 F.2d 1117 (D.C. Cir. 1983), cerl. denied, 467 U.S. 1219 (1984); see notes 342-347 infra and accompanying text.

11. Adams, 743 F.2d at 42; Alliance to End Repression, 742 F.2d at 1007.

12. 106 S. Ct. 3063 (1986) [hereinafter Cleveland Firefighters].

13. For fuller discussion and analysis of this decision, see notes 25-37 infra and accompanying text.

14. E. Meese, Memorandum on Department Policy Regarding Consent Decrees and Settement Agreements (Mfarch 13, 1986) (Internal Department of Justice Memorandum on file with the Stanford Law Review). For an analysis of the guidelines' purpose and likely effectiveness, see Jost, Commentary: The Attomey General's Policy on Consent Decrees and Settlement Agreements, 39 ADMIN. L. REV. 101 (1987).

15. The memorandum states that no federal department or agency should "limit its discretion by consent decree where it would assert that a similar limitation imposed by injunction unduly or improperly constrains executive discretion." E. Meese, supra note 14, at 3 . The memorandum articulates Department of Justice policy not to authorize any consent decree or settlement agreement that: (1) "converts into a mandatory duty the otherwise discretionary authority .... to revise, amend, or promulgate regulations"; (2) "either commits the [federal] department or agency to expend funds .... that have not been budgeted for the action in question, or commits a department or agency to seek a particular appropriation or budget authorization"; (3) "divests the Secretary or agency administrator, or his successors, of discretion committed to him by Congress or the Constitution where such discretionary power was granted to respond to changing circumstances, to make policy or managerial choices, or to protect the rights of third parties." Id. at 3-4. 
does not, however, offer any theory to justify or clarify the enumerated limitations. The guidelines expressly empower the Attorney General to exercise discretion in permitting exceptions to these limitations in particular cases. ${ }^{16}$ And, in fact, the Reagan Administration, like past administrations, has sometimes acted as if it recognized no constitutional limits on the extent to which the executive could bind its policy discretion or cede its constitutional prerogatives through consent agreements. ${ }^{17}$

Despite the ruling in Cleveland Firefighters, there are strong arguments against unlimited executive power to enter consent agreements. Some of the strongest arguments derive from the structure of the Constitution, from the implications of leading Supreme Court decisions, and from long-established legal principles in federal administration. There are also strong practical arguments for giving explicit judicial recognition to such limitations. The troubling outcomes in the recent cases on consent decrees reinforce this conclusion. Neither the underlying constitutional principles nor the practical concerns behind them are adequately served by uncertain rules of self-restraint in the Justice Department.

Because consent agreements are, in many ways, similar to contracts, we begin our argument in Section II by reviewing constitutional and statutory exceptions to the general principle that government must honor its contractual obligations to private parties. As our brief survey indicates, courts have always balanced the government's obligation to honor agreements against its need to retain discretion in broad matters of public policy. Section III relates these "public policy" exceptions to the policy prerogatives of the federal executive branch that are most clearly reserved by the Constitution. We argue that in relation to (a) executive recommendations to Congress, (b) broad spending poli-

16. A concluding paragraph, titled "Exceptions," states that:

The Attorney General does not hereby yield his necessary discretion to deal with the realities of any given case.... [W] ritten approval of the Attorney General, the Deputy Attorney General, or the Associate Attorney General will be required to authorize departure from these guidelines. [Federal attorneys seeking such approval must provide] a concise statement of the case and of reasons why departure from these guidelines will not tend to undermine their force and is consistent with the constitucional prerogatives of the executive or the legislative branches. Id. at 4.

However, the memorandum offers no guidance as to what conditions would be necessary to satisfy these requirements and thus appears to contemplate broad discretion in the Attorney General to approve such exceptions. Id.

17. Thus, for example, in Citizens for a Better Environment v. Gorsuch, 718 F.2d 1117 (D.C. Cir. 1983), cerl. denied, 467 U.S. 1219 (1984), the Reagan Administration asserted that the Environmental Protection Agency ("EPA") was bound by an earlier consent decree to adopt a particular scientific methodology in setting a water pollution standard. The Administration maintained this position even though industry intervenors challenged the particular methodology involved as inappropriate, and the Administration conceded that relevant statutes did not actually require the EPA to adopt this approach. In this case, the Reagan Administration was quite content to "let its hands be tied." See notes 342-347 infra and accompanying text. 
cies pursuant to general appropriations, and (c) ongoing enforcement policies, the Constitution implies definite limits on the remedial authority of courts to control executive action-limits that the executive itself cannot waive in consent agreements.

Section IV reviews five recent cases in which courts of appeals considered charges that the government had violated earlier consent agreements and in which the government, in turn, raised fundamental questions about the enforceability of overly broad decrees. In Section V we critique the ensuing decisions in light of the principles advanced in Section III. We argue that these decisions evade the underlying constitutional issues and may create uncertainty and confusion regarding the status of government consent agreements. Finally, in Section VI we offer practical support for an explicit recognition of the limits on judicial authority to bind the policy discretion of the executive. The very fact that executive agencies often welcome such impositions, we argue, underscores the danger to responsive and accountable policymaking from overly broad consent agreements.

\section{The Obligation of Contracts-and Consent Degrees}

\section{A. The Hybrid Nature of Consent Decrees}

The Supreme Court has noted that consent decrees "have attributes both of contracts and of judicial decrees." 18 A consent decree is like a contract in the elemental sense that it reflects the agreement of both parties: A court cannot enter a consent decree unless both parties consent to every provision of the decree. ${ }^{19}$ Like a contract, moreover, a consent decree binds the parties to what they have actually agreed and not to what they might have claimed or deserved under the law: "[T] he agreement reached normally embodies a compromise ... [where] the parties each give up something they might have won had they proceeded with the litigation." 20

Yet a consent decree differs from an ordinary contract because the court enters it like a judgment on the merits: Entry of a consent decree usually renders the underlying dispute res judicata. ${ }^{21}$ Accordingly, the terms of the decree can be enforced, like any other court order, by contempt citations for noncompliance. ${ }^{22}$ Moreover, because a consent decree is a judicial decree, the issuing court retains the authority under ordinary equitable principles to modify its provisions, even over the ob-

18. United States v. ITT Continental Baking Co., 420 U.S. 223, 236 n.10 (1975).

19. See United States v. Ward Baking Co., 376 U.S. 327, 334 (1964). In Cleveland Firefighters, the Court held that court entry of a consent decree is not contingent on intervenor approval. I06 S. Ct. at 3079-80.

20. United States v. Armour \& Co., 402 U.S. 673,681 (1971).

21. IB J. Moore, J. Lucas \& T. Currier, Moore's Federal Practice $\$ 0.409$ [5] (2d ed. 1984) [hereinafter Moore's].

22. United States v, City of Miami, 664 F.2d 435, 440 (Former 5th Cir. 1981) (en banc) (Rubin, J., concurring). 
jections of one of the parties..$^{23}$ At the same time, because consent decrees directly engage the authority of the entering court, they are subject to certain restrictions that do not apply to ordinary contracts.

In System Federation No. 9l, Railway Employees Department v. Wright 24 the Supreme Court ruled that a consent decree must be modified when there has been a change in the relevant statute because a court's "authority to adopt a consent decree comes only from the statute which the decree is intended to enforce."25 This ruling seemed to establish the principle that a court cannot enter a consent decree that requires more than the court could have ordered on its own authority after a decision on the merits. ${ }^{26}$ This principle seems sensible because the special force of a consent decree derives precisely from the court's involvement. The initial bargaining power of the parties in negotiating the decree is presumably limited by what the parties could expect the court to order on its own if they did not come to terms voluntarily. Thus, where one of the parties to a consent decree cedes more than the utmost a court could have exacted on its own authority, there are grounds to suspect that the decree reflects collusion between the parties or some element of distortion or misrepresentation by one of the parties. ${ }^{27}$

The Supreme Court's 1986 decision in Cleveland Firefighters ${ }^{28}$ adds a new element of complexity, however. That decision concerned a consent decree settling claims that the Cleveland fire department had practiced race discrimination in violation of Title VII of the 1964 Civil Rights Act. The decree pledged Cleveland to hire and promote minority firefighters, whether or not these firefighters had been personal victims of discrimination by the fire department. ${ }^{29}$ The firefighters' union urged the Court to invalidate this decree because it exceeded the express limitation on judicial authority in Title VII that "[n]o order of the court shall require .... the hiring, reinstatement, or promotion of an individual .... if such individual was refused ... employment or advancement ... for any reason other than discrimination on account of race."30 The Court nevertheless upheld the consent decree on the ground that "a federal court is not necessarily barred from entering a

23. United States v. Swift \& Co., 286 U.S. 106, 114 (1932).

24. 364 U.S. 642 (1961).

25. Id. at 651 .

26. The Supreme Court reaffirmed this proposition as recently as 1984 in Firefighters Local Union No. 1784 v. Stotts, 467 U.S. 561, 576 n.9 (1984).

27. Collusion and misrepresentation are among the traditional grounds for refusing to enforce consent agreements. See Note, The Consent Judgment as an Instrument of Compromise and Settlement, 72 HaRV. L. REV. 1314 (1959).

28. 106 S. Ct. 3063 (1986).

29. See id. at 3069 .

30. Id. at 3071; Civil Rights Act of $1964 \S 706(\mathrm{~g}), 42$ U.S.C. $\$ 2000 \mathrm{e}-5(\mathrm{~g})(1982)$. On the day that Cleveland Firefighters was decided, the Supreme Court ruled in Local 28 of Sheel Metal Workers International Association v. EEOC that this provision of the Civil Rights Act does not serve as an absolute bar to the ordering of preferential relief benefitting individuals who were not actual victims of discrimination. 106 S. Ct. 3019 (1986). 
consent decree merely because the decree provides broader relief than the court could have awarded after trial." 31

The majority opinion in Cleveland Firefighters conceded, however, that "a federal court is more than a 'recorder of contracts' from whom the parties can purchase injunctions" 32 and accordingly reaffirmed that "a consent decree must "come within the general scope of the case made by the pleadings,' and must further the objectives of the law upon which the complaint was based." 33 More importantly, while holding that "the limits placed [by statute] on the remedial authority of a federal court ... are not implicated by voluntary agreements," the Court still acknowledged that such an agreement could be entered and enforced by the courts only "to the extent that the consent decree is not otherwise shown to be unlawful."34 By its own terms, then, the decision in Cleveland Firefighters does not seem to overrule lower court decisions invalidating consent decrees based on "the inability of a public officer to bind the public by agreeing to a consent judgment beyond his authority or for a collusive purpose" 35 or based on "the inability of parties to effectuate an agreement void on grounds of public policy by making it the basis of a consent judgment." 36

In sum, Cleveland Firefighters indicates that not every limitation on the independent remedial authority of federal courts necessarily implies exactly parallel limits on judicial authority to enter and enforce consent decrees. But the decision reaffirms that what parties cannot agree to in ordinary contracts, they cannot make binding through consent decrees. Although judicial deference may be justified when reviewing the

31. Cleveland Firefighters, $106 \mathrm{~S}, \mathrm{Ct}$. at 3077 . Three dissenting justices protested that this decision was an improper departure from the rule affirmed in System Federation and other decisions. The majority opinion is also surprising in light of the Court's opinion in Sheet Metal Forkers. Cleveland Firefighters could be interpreted as being restricted to the peculiar circumstances of civil rights disputes under Title VII because the majority opinion repeatedly stressed the importance of interpreting Title VII in light of the strong legislative preference for voluntary settlement of discrimination claims. The opinion in Cleveland Firefighters, written by Justice Brennan, refers frequently to the Court's decision in United Steelworkers of America v. Weber, 443 U.S. 193 (1979), which held that statutory language in Title VII, seemingly prohibiting preferential treatment or racial quotas, was directed at quotas imposed by government but not quotas established in voluntary agreements. According to Justice Brennan's reconstruction of the legislative history, Congress, when enacting such limitations as Section 706(g), was "particularly concerned to avoid undue federal interference with managerial discretion" rather than to establish a principle of nondiscrimination protecting white employees along with minorities. $106 \mathrm{~S}$. Ct. at 3074 (citing Weber, 443 U.S. at 205-07). Conversely, the dissenters in Cleveland Firefighters (Justices White, Rehnquist, and Chief Justice Burger) read the legislative history of Title VII as intending protections for white employees as well as minority group employees. Recently, in Johnson v. Transportation Agency, I07 S. Ct. 1442 (1987), the Court relied on Weber, holding that Title VII does not prohibit the adoption of affirmative action plans by public employers.

32. $106 \mathrm{~S}$. Ct. 3077 (quoting 1B MOORE's, supra note 21, at 90.409 [5]).

33. Id. (quoting Pacific R.R. v. Ketchum, 101 U.S. 289, 297 (1880)).

34. Id. at 3078.

35. 1B MOORE's, supra note 21 , at $90.409[5]$.

36. Id. 
employment contracts of municipal service departments, ${ }^{37}$ contracts with federal executive agencies are, in fact, subject to some very important limitations. These limitations are grounded in basic constitutional principles. Limitations on the enforceability and validity of consent decrees with federal agencies, then, are not simply a matter of particular limitations on judicial authority of the sort urged in Cleveland Firefighters. Courts cannot enforce (and therefore should not enter) certain kinds of federal consent decrees, not simply because of statutory restrictions limiting the authority of courts to order the result involved, but also because articles I and II of the Constitution forbid executive officials from making such agreements.

\section{B. Limitations on the Obligation of Government Contracts}

The Framers were very respectful of the right to make and enforce contracts. Article I contains a specific prohibition on state laws "impairing the Obligation of Contracts." 38 And while the Constitution as originally enacted imposed no explicit prohibition of this kind on federal actions, that omission was largely remedied by the addition of the Bill of Rights. Because contract rights are a form of property, they are protected against many forms of federal interference by the fifth amendment's prohibition on the deprivation of property without "due process of law" and on the taking of property without "just compensation." 39 Given the evident concern of the Framers for protecting con-

37. There are a number of ways in which local officials can have a different status than federal executive officers under the Constitution. First, the Constitution imposes a number of structural limitations on federal operations, in the name of the separation of powvers, that do not apply to state and local governments. The organization of county and municipal governments can, and frequently does, depart in numerous ways from the tripartite arrangement of powers operating at the federal level (and, with slight variations, in all state governments), without raising any constitutional difficulties. Second, federal constitutional law recognizes distinctions between the constitutional status of local government operations and state governments. For example, the eleventh amendment guarantee of sovereign immunity-prohibiting suits against a state without its consent-protects only state governments and not county, city, or lesser governmental units. See, e.g., Cowles v. Mercer County, 74 U.S. (7 Wall.) 118 (1868); Markham v. City of Newport News, 292 F.2d 711 (4th Cir. 1961). The courts have regarded these lesser governmental units as more akin to private corporations than to states for purposes of sovereign immunity. See Cowles, 74 U.S. at 122. Federal courts have accordingly disregarded state statutes that attempt to confine suits against these local operations to the state courts. See, e.g., Markham, 292 F.2d at 716.

38. U.S. Const. art. I, § 10, cl. 1. Madison declared that "laws impairing the obligation of contracts are contrary to the first principles of the social compact." THE FEDERALIST No. 44, at 282 (J. Madison) (C. Rossiter ed. 1961). For fuller discussion of the importance attributed to this clause by the Framers, see B. WRIGHT, ThE Contract Clause of the Constrsution 326 (1938).

39. In Lynch v, United States, 292 U.S. 571, 579 (1934), the Supreme Court held that legislation cancelling government war risk life insurance policies was unconstitutional because private claims "arising out of contract with [the federal government] are protected by the Fifth Amendment" and cannot be restricted unless "the action taken falls with the federal police power or some other paramount power." But since then the Court has upheld several retroactive restrictions on claims of federal contractors where some general public concern has been evident, even if not strictly within the traditional conception of "the police power." Thus, for example, in Federal Housing Administration v. The Darlington, Inc., 358 U.S. 84 
tract rights along with other forms of property, it was not a very big step for the Supreme Court to hold, in its early celebrated decisions in Fletcher v. Peck ${ }^{40}$ and Dartmouth College v. Woodward, ${ }^{41}$ that constitutional protections for contracts apply even to contracts with the government.

Yet, the notion that government could be held to account in the courts for its contract obligations has always been somewhat qualified: During the debates over ratification of the Constitution, Hamilton, Madison, Marshall, and other leading figures agreed that the Constitution would not override the established principle of "sovereign immunity"-the principle that governments cannot be sued without their consent. ${ }^{22}$ In 1793, when the Supreme Court allowed a holder of unpaid state debts to sue the State of Georgia without its consent, ${ }^{43}$ the public reaction was so severe that the eleventh amendment was quickly added to the Constitution to reaffirm the claim of the states to sovereign immunity. ${ }^{44}$ The parallel claims of Congress to grant or withhold waivers of sovereign immunity for suits against the federal government seem never to have been seriously questioned. ${ }^{45}$

(1958), the Court upheld the validity of a legislative restriction on the use of housing constructed under a Federal Housing administration-insured mortgage that had been issued without this restriction five years earlier. The Court upheld a similar ex post facto restriction on housing contractors in Thorpe v. Housing Authority, 393 U.S. 268 (1969).

40. IO U.S. (6 Cranch) 87 (1810).

41. 17 U.S. ( 4 Wheat.) 517 (1819).

42. The Court reviewed arguments from leading figures of the era regarding the continuing force of sovereign immunity in Principality of Monaco v. Mississippi, 292 U.S. 313, 32324 (1934).

43. Chisholm v. Georgia, 2 U.S. (2 Dall.) 419 (1793). Justice Iredell argued in a forceful dissent that the Framers had not intended to eliminate sovereign immunity. Id. at 429-49.

44. The Chisholm decision aroused such ire in Georgia that one house of the state legislature voted to make a capital crime any attempt to pursue financial claims against the state by "compulsory [judicial] process." The eleventh amendment provided a more reasoned response to the decision. See C. Jacobs, The Eleventh Amendment ANd Sovereign IMmunity 56-57, 47-74 (1972).

The eleventh amendment, ratified in 1798, reads: "The Judicial power of the United States shall not be construed to extend to any suit in law or equity, commenced or prosecuted against one of the United States by Citizens of another State, or by Citizens or Subjects of any Foreign State." U.S. ConST. amend. XI. Read literally, the amendment might not seem to guarantee the defense of sovereign immunity for suits against a state brought by one of its own citizens. Yet the Supreme Court has offered a broad reading of the amendment. Thus, in Hans v. Louisiana, 134 U.S. 1 (1890), the Court ruled that the eleventh amendment overruled Chisholm and restored the original conception of sovereign immunity. Id. at 12-14. This construction prevents states from being sued by their own citizens without state consent. In Principality of Monaco v. Mississippi, 292 U.S. 313 (1934), the Court held that the eleventh amendment restored the defense of sovereign immunity to states in suits by foreign nations, even though the amendment only refers to suits by "citizens or subjects" of foreign states. Id. at $330-31$.

45. As Chief Justice Marshall stated in Cohens v. Virginia: "The universally received opinion is, that no suit can be commenced or prosecuted against the United States; that the judiciary act does not authorize such suits." 19 U.S. (6 Wheat.) 264, 411-12 (1821). The Court set out, with considerably more fullness, the scope of the defense of sovereign immunity for suits against the federal government in Murray's Lessee v. Hoboken Land \& Improvement Co., 59 U.S. (18 How.) 272, 283-84 (1855). The doctrine did not, of course, prevent suits against federal officials as individuals, but some suits of this kind have been treated as suits against the United States and therefore subject to the defense of sovereign immunity. 
Even where the state governments or Congress waived sovereign immunity, which became rather common in the course of the nineteenth century, ${ }^{46}$ the concern behind this ancient doctrine did not become altogether irrelevant. The business of government is not quite the same as private business, even where "the sovereign" is conceived as the agent of the people's will. Democratic principles exacerbate the tension between government's obligation to individual contract partners and its obligation to govern in the general interest, for democracy presupposes that the voters can always hold government to account for its decisions and demand that they be changed. As Justice Brennan has observed, "[t]he Framers fully recognized that nothing would so jeopardize the legitimacy of a system of government that relies upon the ebbs and flows of politics to 'clean out the rascals' than the possibility that those same rascals might perpetuate their policies simply by locking them into binding contracts." 47

This problem was well recognized by federal courts, even in the latter part of the nineteenth century when judicial solicitude for contract rights and property rights was especially pronounced. One of the principal doctrinal devices for limiting the problem dates from that era.

In the course of the nineteenth century, the Supreme Court developed a sharp distinction between the police powers of governmentgovernment in its capacity as sovereign regulator of otherwise private property and private conduct-and those governmental functions more directly analogous to private activity, where the state, as property owner, engages in buying, selling, or granting property to others. ${ }^{48}$

See, e.g., Hawaii v. Gordon, 373 U.S. 57 (1963); New Mexico v. Lane, 243 U.S. 52 (1917); Oregon v. Hitchcock, 202 U.S. 60 (1906).

46. At the federal level, financial claims against the United States were considered and resolved by private bills in Congress until the middle of the nineteenth century. Congress established the Court of Claims in 1855, 10 Stat. 612, 13 Rev. Stat. \$1049-58 (1878), to "hear and determine" most types of money claims against the United States (other than tort claims). But the court's determinations initially were not regarded as binding judgments and could only be enforced by the separate enactment of particular private bills in Congress. In 1866, Congress made judgments of the Court of Claims binding and subject to appellate review in the Supreme Court, 14 Stat. 9, 13 Rev. Stat. $\$ 1059$ (1878). Subsequently, in the Tucker Act of 1887,24 Stat. 505 (codified at 28 U.S.C. $\$ \$ 1346$ (1982)), Congress enlarged the jurisdiction of the Court of Claims and bestowed concurrent jurisdiction on federal district and circuit courts for claims under $\$ 10,000$.

47. United States Trust Co. v. New Jersey, 431 U.S. 1, 45 (1977) (Brennan, J.. dissenting).

48. It was not, however, simply or even primarily in contract clause cases that the courts struggled to articulate and define the "police power." Before the Civil War, the police power was sometimes invoked in commerce clause cases, where the Court struggled to distinguish the regulatory powers necessarily reserved to the states from those matters of commercial regulation preempted by congressional power to regulate interstate commerce. See, e.g., Mayor of New York v. Miln, 36 U.S. (11 Pet.) 102 (1837). The scope of the police powers subsequently became a sharply disputed issue in substantive due process cases as well, where the Court sought to distinguish permissible regulation from improper interference with personal liberty or private property. But even in these cases, the Court conceded that the precise scope of the police power could not be neatly or comprehensively defined. In Lochner v, New York, 198 U.S. 45 (1905), for example, where the Supreme Court struck down a maxi- 
The Court then developed the doctrine that the protections of the contract clause do not apply to exercises of the police power. ${ }^{49}$ As a logical corollary, the Supreme Court insisted that private parties could not evade regulatory restrictions by contracting with a state for guarantees against the exercise of its regulatory powers. Such contracts could not be valid, the Court maintained, because the police power cannot be constrained by contract. ${ }^{50}$

Thus, in Stone v. Mississippi the Supreme Court denied that a state legislature's grant of a charter to operate a lottery game (in consideration of large payments to the state treasury) could prevent the legislature from subsequently prohibiting lotteries. ${ }^{51}$ The expectations founded on the charter could not be treated as a contract claim binding the state because "the legislature cannot bargain away the police power of a State." 52 As Chief Justice Waite explained:

[T] he power of governing is a trust committed by the people to the government, no part of which can be granted away. The people, in their sovereign capacity, have established their agencies for the preservation of the public health and the public morals, and the protection of public and private rights. These several agencies can govern according to their discretion ... while in power; but they cannot give away nor sell the discretion of those that are to come after them, in respect to matters the government of which, from the very nature of things, must "vary with varying circumstances." 53

In the late nineteenth century and the early decades of this century, the Supreme Court repeatedly reaffirmed the doctrine that states cannot "bargain away" their police powers. ${ }^{54}$ As recently as 1977 , in

mum hours law for bakery workers for exceeding the legitimate police powers of the state, the Court nonetheless conceded that "the exact description and limitation of [such police powers] have not been attempted by the courts." Id. at 53. The Lochner decision declined "any attempt at a more specific limitation" beyond the claim that such powers "relate to the safety, health, morals and general welfare of the public." Id.

49. Contract clause doctrine was not developed simply for the sake of government contracts. Some doctrine was necessary to reconcile the constitutional guarantee against "impairing the obligation of contracts" with the power of the states to regulate purely private activity. Otherwise, a brewer might claim the constitutional right to an exemption from a statute prohibiting beer sales on the ground that the law "impaired the obligation" of contracts for the sale of beer. But the Supreme Court dismissed the claim. See Mugler v. Kansas, 123 U.S. 623 (1887). Justice Holmes later articulated the principle more concisely: "One whose rights, such as they are, are subject to state restriction, cannot remove them from the power of the state by making a contract about them." Hudson County Water Co. v. McCarter, 209 U.S. 349,357 (1908).

50. Mfugler, 123 U.S. at $664-65$.

51. 101 U.S. 814,817 (1879).

52. Id. at 817 .

53. Id. at 820 .

54. See, eg., Atantic Coast Line R.R. v. City of Goldsboro, 232 U.S. 548, 558-59 (1914) (upholding regulatory limitations on use of land granted to railroad by state contract); Minneapolis \& St. L. Ry. v. Emmons, 149 U.S. 364, 366-67 (1893) (upholding state law requiring railroads to build fences and cattle guards, even where railroads had contracted for right-ofway without such conditions); Butchers' Union Slaughter-House and Live-Stock Landing Co. v. Crescent City Live-Stock Landing and Slaughter-House Co., 111 U.S. 746, 750 (1884) (up- 
United States Trust Co. v. New Jersey, ${ }^{55}$ the Court affirmed the rule that "the strictures of the Contract Clause" must be limited by "the "essential attributes of sovereign power' necessarily reserved by the States to safeguard the welfare of their citizens." 56 The Court's opinion noted that the "formalistic distinctions" on which this rule was based still "contain an important element of truth." 57

The doctrine of Stone v. Mississippi has its federal analog in the doctrine of "sovereign breach" or the "defense of sovereign acts." Since the mid-nineteenth century, when Congress created the Court of Claims and waived sovereign immunity for a broad range of financial claims, ${ }^{58}$ federal agencies entering into contracts with private parties have been liable for damage actions for their breach of such contracts. But the Supreme Court has long held that "the United States when sued as a contractor cannot be held liable for an obstruction to the performance of the particular contract resulting from its public and general acts as a sovereign." 59 Thus in the classic case, the federal government was held not liable for breach of contract when a federal agency failed to perform its promise to deliver certain silk shipments by a specified date because the government had imposed an embargo on the wartime shipment of luxury goods. ${ }^{60}$ Relying on this and other decisions by the Supreme Court, the Court of Claims eventually formulated the doctrine in these encompassing terms: "Actions of a general and public character, implementing programs in the national interest, are considered to be acts of the sovereign for which defendant [the contracting federal agency] cannot be held liable in damages."61

These formulations are notable for defining "sovereign acts" in terms that go beyond classic conceptions of the police power to em-

holding state revocation of a monopoly on slaughtering previously granted by legislative charter).

55. 431 U.S. 1 (1977). United States Trust Co. was the first case in over forty years in which the Supreme Court found a state enactment to be in violation of the contract clause.

56. Id. at 21 (quoting Home Loan Ass'n. v. Blaisdell, 290 U.S. 435, 435 (1934)).

57. Id. at 25 .

58. See note 46 supra.

59. Horowitz v. United States, 267 U.S. 458, 461 (1925). In the most technical terms, then, the doctrine of sovereign breach may be distinguished from the police power doctrine under the contract clause: Where the former holds that certain kinds of contracts are necessarily void from the outset, the latter defends government against charges of breach of contract even where the contract would not be invalid in itself. But the effects of the sovereign breach doctrine are the same: Government may not be held to promises not to exercise "sovereign" powers. At most, the government may agree to compensate the other party for costs incurred by the contract breach, but the other party can never enforce specific performance when broader government policy prerogatives are at stake. See notes 63.64 infra and accompanying text.

60. Horowitz v. United States, 267 U.S. 458, 460-61 (1925).

61. Wunderlich Contracting Co. v. United States, 351 F.2d 956, 967 (Ct. Cl. 1965). For more recent applications of the sovereign breach doctrine, see Pacific Power \& Light Co. v. Duncan, 499 F. Supp. 672 (D. Or. 1980); Lebanon Chemical Corp. v. United States, 5 Cl. Ct. 812 (Ct. Cl. 1984); Reynolds Metal Co. v. United States, 438 F.2d 983 (Ct. Cl. 1971), cert. denied, 404 U.S. 825 (1971); Air Terminal Servs. v. United States, 330 F.2d 974 (Ct. Cl. 1964), cerl. denied, 379 U.S. 829 (1964). 
brace a range of other "general and public" governmental acts. But the sovereign breach doctrine differs from the more recent doctrine, expressed in post-New Deal contract clause cases, that state governments may abrogate contracts, including financial contracts, when such an abrogation is "reasonable and necessary to serve an important public purpose."62 In contrast to these contract clause rulings, the sovereign breach doctrine does not seek to define the extent to which government may escape from its contracts; rather, it limits what government may promise in the first place, given its need for ongoing policy discretion.

Nothing prevents the federal government from insuring its contractors against unfavorable changes in public policy by including explicit contract provisions promising to "pay the other contracting party the amount by which its costs are increased by the Government's sovereign act." 63 But the federal government simply "cannot make a binding contract that it will not exercise a sovereign power." 64 In keeping with this logic, the Court of Claims (following an early ruling of the Supreme Court) disavowed authority to order specific performance by the federal government in contract disputes. ${ }^{65}$ The Court of Claims has also held that the government does not have the same obligations as do private contracting parties to refrain from actions that might frus-

62. United States Trust Co. v. New Jersey, 431 U.S. 1, 25 (1977). In 1934, the Court in Home Loan Ass'n v. Blaisdell, 290 U.S. 398 (1934), seemed to loosen the traditional contract clause constraints. It then upheld a law postponing the foreclosure remedies of creditors in mortgage contracts as a reasonable state response to the economic pressures of the Depression. Rather than relying upon specific doctrinal exceptions, Blaisdell held that the constitutional prohibition against impairing the obligation of contracts was "not an absolute one and is not to be read with literal exactness like a mathematical formula." Id. at 428. Subsequent decisions affirmed that contract modifications might be necessary to serve a variety of public purposes and that courts must acknowledge "wide discretion on the part of the legislature in determining what is and is not necessary." East N. Y. Sav. Bank v. Hahn, 326 U.S. 230, 233 (1945). Sec also City of EI Paso v. Simmons, 379 U.S. 497, 508-09 (1965) (where the Court cites this principle with approval). But if the contract clause is to retain any force, there must be some limits on the kind of public purpose that will justify governmental interference with contractual obligations. And limits of some sort must also apply to government measures that abrogate contract claims against the government. In United States Trusl Co., the Court suggested that state laws impairing government contracts ought to be subject to greater scrutiny since the state's self-interest is involved. 431 U.S. at 26. Accordingly, while conceding that the state's purpose was proper and legitimate, the Court still found that the contract clause prevented New Jersey from cancelling certain guarantees on Port Authority bonds, asserting that the state might have adopted other means to achieve its purposes. Id. at 29-31. But where contracts are void because they promise something the state has no power to pledge, the state need not have any special justification for violating such non-binding obligations. A measure that violates an improper or unenforceable "contract" might be challenged as an improper exercise of state authority on some other grounds, but it certainly cannot be challenged for violating the contract clause.

63. Amino Bros. Co. v. United States, 372 F.2d 485, 491 (Ct. Cl.), cerL denied, 389 U.S. 846 (1967)

64. Id.

65. United States v. Jones, 131 U.S. 1 (1889); Zimmerman v. United States, 422 F.2d 326 (3d Cir.), cert. denied, 399 U.S. 911 (1970); Carney v. United States, 462 F.2d 1142 (Ct. Cl. 1972); Slobojan v. United States, 136 Ct. Cl. 620 (Ct. Cl. 1956). 
trate the other party's performance. ${ }^{66}$

A different approach to limiting government contract obligations, also developed in nineteenth century contract clause cases, is the doctrine that valid government contracts are to be construed narrowly (that is, in favor of the government) where their provisions are ambiguous. ${ }^{67}$ With respect to otherwise valid contracts, the doctrine has little application in contemporary federal contract law. ${ }^{68}$ But several current doctrines in federal contract law (and related fields) build upon this traditional presumption against the acceptance of mere implied obligations by emphasizing the need for explicit consent to agreements from the appropriate governmental authority.

One example of such a doctrine is the special limitations on federal financial contracts. The common law of agency generally treats contracts made by an agent as binding, even where not directly authorized by the principal, if the other party to the contract had grounds to rely on the agent's authority. ${ }^{69}$ Governmental financial contracts, by contrast, must be directly authorized by Congress. If a government official does not have statutory authority to commit government funds, any contract that official signs is unenforceable, regardless of the other party's good faith expectations in entering the agreement. ${ }^{70}$

Gourts have developed similar doctrines limiting the force of agreements with the government that are not formal contracts. Here too, equitable principles that apply in solely private agreements do not apply in the same way to the government. The general rule is that regardless of the expectation interests at stake, promissory estoppel does not run against the government to the extent that it does against private

66. See, e.g., Wunderlich Contracting Co. v. United States, 351 F.2d 956 (Ct. Cl. 1965) (rejecting claim that government had violated an implied duty under construction contract when it pursued other construction projects in the same area, making Wunderlich contract more difficult and more costly to complete). The contractor "has no legal cause to complain if it is the sovereign that renders his performance more difficult to complete." Id. at 967.

67. This doctrine was first articulated by the Supreme Court in Charles River Bridge v. Warren Bridge, 36 U.S. (11 Pet.) 419 (1837), where the Court stressed that in contract or grant disputes with "the public, nothing passes by implication." Id. at 546 . In Fertilizing Co. v. Hyde Park, 97 U.S. 659,666 (1878), the Court reaffirmed that in government contracts, "[n]othing is to be taken as conceded [by the government] but what is given in unmistakable terms, or by implication equally clear."

68. Early in this century, for example, the Supreme Court ruled that where federal contract specifications prescribed the character, dimensions, and location of construction work, the government had given an implicit warrant that the contractor would be able to complete the project within the agreed-upon period of time if these specifications were met, even though such was not explicitly stated in the contract. United States v. Spearin, 248 U.S. 132 (1918). For a more recent decision holding that the federal government was liable for breach of this sort of implied warranty, see Laburnum Constr. Corp. v. United States, 325 F.2d 451 (Ct. Cl. 1963).

69. See, for example, the treatment of "apparent authority" in RESTATEMENT (SECOND) of AGENCY $\$ \$ 8,27$ (1958). For an extended analysis of the differences in this area between government and private contracts, see Whelan \& Dunigan, Government Contracts: Apparent Authority and Estoppel, 55 GEo. L.J. 830 (1967).

70. See notes $71-73$ infra. 
parties. $^{71}$ Good faith reliance on the assurances of government officials generally is an insufficient ground on which to allow recovery against the government when such recovery would not otherwise be forthcoming, ${ }^{72}$ and generally is no defense to a government enforcement action. ${ }^{73}$ Prosecutors may be held to particular plea bargaining agreements ${ }^{74}$ and lower courts have held that in exceptional cases, such as where government officials have actively misled a particular party, and failure to provide a remedy would create extreme hardship or injustice, promissory estoppel may lie against the government. ${ }^{75}$ But the general rule, repeatedly reaffirmed, is that government policy may not be

71. "[I] is ... well settled that the Government may not be estopped on the same terms as any other litigant." Heckler v. Community Health Servs., 467 U.S. 51, 60 (1984) (rejecting claim that Department of Health and Human Services was estopped from seeking to recoup funds improperly granted because the recipient had expanded its operations in reliance on this funding). The majority opinion, while noting that the arguments for such a view were "substantial," found it

unnecessary to decide this case, to say that there are no cases in which the public interest in ensuring that the Government can enforce the law free from estoppel might be outweighed by the countervailing interest of citizens in some minimum standard of decency, honor, and reliability in their dealings with their Government. Id. at 60-61 (emphasis in original). Justice Rehnquist, joined by Chief Justice Burger, filed a separate concurring opinion objecting to holding the door open to estoppel claims even to this limited extent and noting that in no earlier case "have we ever held the Government to be estopped by the representations or conduct of its agents." Id. at 67.

72. In Federal Crop Ins. Corp. v. Merrill, 332 U.S. 380 (1947), the Court denied recovery to a planter who had relied on assurances of a government agency regarding the agency's coverage through a crop insurance policy, although the Court acknowledged that this representation would have estopped a private insurance carrier. In Schweiker v. Hansen, 450 U.S. 785 (1981), the Court similarly rejected the estoppel plea of a Social Security beneficiary who had relied on the misrepresentation of a government employee and stood to lose twelve months of Social Security benefits. The Court left undecided whether the government would be estopped in cases where its employees' conduct constituted "affirmative misconduct." Id. at 788 .

73. The Court has repeatedly held that the conduct or assurances of immigration officials cannot be used to estop subsequent enforcement of the immigration laws. See INS v. Miranda, 459 U.S. 14 (1982); INS v. Hibi, 414 U.S. 5 (1973); Montana v. Kennedy, 366 U.S. 308 (1961).

74. The federal courts "have understandably drawn heavily on the ready analogies of substantive and remedial contract law to supply the body of doctrine necessary to order plea bargaining practices and to afford relief to defendants aggrieved in the negotiating process." Cooper v. United States, 594 F.2d 12, 15 (4th Cir. 1979). For recent cases supporting the relevance of contract law principles in assessing plea bargain disputes, see United States v. Mooney, 654 F.2d 482, 486 (7th Cir. 1981); United States v. Arnett, 628 F.2d 1162, 1164-65 (9th Cir. 1979); United States v. MfeIntosh, 612 F.2d 835, 837 (4th Cir. 1979); Jones v. Estelle, 584 F.2d 687, 689 ( 5 th $\mathrm{Cir}$. 1978). However, a key distinction between ordinary contracts and plea bargain agreements is that the latter must be approved by the trial judge and "ordinarily neither party is justified in relying substantially on the bargain until the trial court approves it." 1 C. Wright, Federal PRACTICE AND Procedure § 175.1 (1982). The Supreme Court has held that when the prosecutor fails to live up to one side of the bargain, trial courts retain broad discretion in deciding whether to order specific performance or simply to allow the defendant to change the plea. See Santobello v. New York, 404 U.S. 257 (1971); for a broader discussion, see Vanore, Criminal Law-Enforcement of Plea Bargaining Agreemenls, 51 N.C.L. REv. 602 (1973) (student author).

75. Sez Cinciarelli v. Reagan, 729 F.2d 801 (D.C. Cir, 1984); Donovan v. Local No. 120 , Laborers' Int'l Union, 683 F.2d 1095 (7th Cir, 1982); Michigan Wis. Pipeline Co. v. WilliamsMcIVillians Co., 551 F.2d 945 (5th Cir. 1977). 
bound by the mistaken or unauthorized advice or action of lower level officials.

In contrast to the sovereign breach cases (or the state police power cases), the immediate question in estoppel cases (as in the unauthorized spending cases) is not whether the government may bind itself by commitments to private parties, but who within the government has the authority to make binding commitments. But, here too, the ultimate question is not whether the government has good grounds to escape from the particular obligation, but whether the obligation was actually valid or properly binding. ${ }^{76}$

Notwithstanding these limitations, the federal government, like a state government or municipality, may still make legally binding and judicially enforceable agreements in a wide range of situations. ${ }^{77}$ So long as it continues to waive the bar of sovereign immunity to direct legal challenges, Congress may be prevented from enacting abrogations of federal contracts or agreements in many situations. ${ }^{78}$ But the doctrines that limit the binding force of government contracts do not merely protect legislative prerogatives or legislative control over spending. Thus, the sovereign breach doctrine in federal contract law applies to executive acts with as much force as it does to legislative enactments. ${ }^{79}$ So too, the doctrine against enforcing unauthorized commitments helps to protect the policy discretion of the executive, along with the spending authority of Congress.

In sum, even if consent agreements were regarded as a pure form of contract, some types of consent decrees would still be invalid and unenforceable because there are independent limitations on the validity or enforceability of government contracts in various circumstances. These

76. To prevail against contract clause challenges to laws interfering with otherwise valid contracts, the state must demonstrate a compelling interest. Mere fiscal concerns have been insufficient for this purpose. "If a State could reduce its financial obligations whenever it wanted to spend the money for what it regarded as an important public purpose, the Contract Clause would provide no protection at all." United States Trust Co. v. New Jersey, 431 U.S. 1, 26 (1977). In United States Trust Co., the Supreme Court ruled that New Jersey's need to cope with a $\$ 24.9$ million rail transit deficit was not a sufficiently compelling interest to justify its abrogation of contractual commitments to public bond holders. See id at 12-13. By contrast, in federal estoppel cases, the government may repudiate previous understandings, even if such repudiation accomplishes nothing more than the saving of public funds, and even if the amounts involved are relatively small. For example, in Heckler v. Community Health Servs., 467 U.S. 51 (1984), the Department of Health and Human Services ("HHS") was alIowed to recover improper reimbursements of $\$ 7,694, \$ 32,460$, and $\$ 31,326$ that had been paid out over a 3-year period, even though the recipient had claimed reimbursements in honest reliance on the advice of HHS officials. The difference is readily explained: The government does not need to cite a particularly compelling reason to "take back" what it has never given up. The premise of the estoppel cases is that unauthorized assurances by government officials cannot be construed as binding commitments or genuine obligations to begin with.

77. See, e.g., Amino Bros. Co. v. United States, 372 F.2d 485 (Ct. Cl.), cert. denied, 389 U.S. 846 (1967),

78. See note 38 supra.

79. See, e.g., Amino Bros., 372 F.2d at 485; Wunderlich Contracting Co. v. United States, 351 F.2d 956 (Ct. Cl. 1965). 
limitations are designed to preserve governmental policy discretion and accountability for actual policy choices. But quite apart from the limitations on government contracts, the Supreme Court has held that certain executive prerogatives must remain inalienable under the Constitution. Such holdings suggest that limitations on governmental contracts are merely particular applications of more general and fundamental constitutional limitations. We will elaborate upon this position in the next section.

\section{Judicial Recognition of Inalienable Executive Powers}

The Supreme Court has frequently shown great deference to the policymaking responsibilities of the federal executive and, in some cases, has protected presidential policy prerogatives even against the contrary will of Congress. ${ }^{80}$ In such cases, the Court has emphasized that there are definite constitutional limits on the extent to which one president may bargain away the policy prerogatives of subsequent presidents, even when bargaining with Congress. If there are limits on how much executive authority a president can bargain away to Congress, similar limits should constrain bargains with private litigants in consent agreements. ${ }^{81}$

Immigration and Naturalization Service v. Chadha ${ }^{82}$ provides one of the clearest examples of such limitations. In that case, the Supreme Court ruled that "legislative veto" provisions are unconstitutional infringements on presidential authority. Such provisions, incorporated into various legislative enactments, seek to give Congress the power to nullify otherwise valid executive regulations or decisions by a disapproval vote in one or, in some versions, both houses. In Chadha, the Court held that congressional resolutions can never have the force of law unless "presented" to the president to sign or veto, as the Constitution

80. See, e.g., Bowsher v. Synar, 106 S. Ct. 3181 (1986); INS v. Chadha, 462 U.S. 919 (1983); Buckley v. Valeo, 424 U.S. 1 (1976); Myers v. United States, 272 U.S. 52 (1926).

81. This claim may seem intuitively obvious: Surely, what may not be ceded even to Congress-which gives the law to the executive in so many respects-may not be ceded to mere private parties, who have no general authority or responsibility for the making of public policy. Is this reasoning too simple? If the separation of powers is regarded primarily as a check on excessive concentration of authority, could it not be argued that ceding executive prerogatives to private parties is, after all, less objectionable than ceding them to a potentially overweening Congress? Plausible as such doubts may seem, we believe they are misplaced and that the unqualified claim advanced in the text remains the soundest view. For even where executive prerogatives are originally ceded to private parties, the consequence is still to make them unavailable as a check on Congress. Moreover, the premise of the doubter's challenge-that the separation of powers is simply a device for ensuring the dispersal of poweris, itself, too simple. As the Supreme Court has acknowledged, the reservation of certain constitutional prerogatives to the executive is not merely intended to disperse power but to focus responsibility on the executive for certain kinds of decisions. See note 134 infra. This latter aspect of the Framers' intention, even more surely than their concern for dispersing power, would be betrayed by allowing the executive branch to bargain away its constitutional responsibilities to private parties.

82. 462 U.S. 919 (1983). 
requires. The Court was not persuaded by the fact that several past presidents have agreed to legislative veto provisions. The Court was also not swayed by the fact that President Kennedy had approved the statute containing the particular legislative veto provision at issue in Chadha. ${ }^{83}$ In effect, the Court ruled that the president's constitutional responsibilities in the legislative process can never be waived, even with the president's consent.

Whereas Chadha emphasizes presidential prerogatives in the legislative process, other decisions, from Meyers v. United States in 1926 to Bowsher v. Synar in 1986, affirm that the president also has certain inalienable constitutional prerogatives in the administration of existing laws. ${ }^{84}$ Myers was a suit for back pay by a federal postmaster who had been peremptorily removed from office by President Wilson. The postmaster argued that his dismissal was invalid because a nineteenth century statute required the consent of the Senate for the dismissal of postmasters, and such consent had not been obtained in his case. The Supreme Court did not dispute that the statute would have given Myers a legitimate claim to the continuance of his salary if the statute had been constitutional. But the Court ruled that the statute was constitutionally invalid because it inhibited presidential control of executive policy. ${ }^{85}$ The Court held that even if this interference with presidential responsibility had been approved by earlier presidents, it could not be binding on later administrations. ${ }^{86}$ Otherwise, the Court reasoned, presidents would be unable to control their subordinates or to maintain "that unitary and uniform execution of the laws which Article II of the Constitution evidently contemplated in vesting general executive power in the President alone."87

Even those cases that have upheld limitations on the president's removal power have stressed that such limitations are only constitutionally acceptable for the insulation of quasi-judicial functions, as

83. In fact, every president since Herbert Hoover, the first president confronted with a legislative veto provision, has expressed doubts about the constitutional propriety of at least some legislative veto measures. See J. Bolton, The Legrslative Veto: Unseparating the Powers 10-13 (1977). Presidents frequently suppressed their objections in their eagerness to win new statutory grants of authority when Congress would agree to such grants only with a legislative veto provision attached. Presidents, in other words, quite literally "bargained away" their constitutional veto power to gain other powers by statutory delegation. Id. at 10$11 \&$ n.24. Under these circumstances, it is hardly surprising that the Supreme Court gave little weight to presidential acquiescence to legislative veto provisions in various statutes. Compare Nixon v. Administrator of Soc. Servs., 433 U.S. 425 (1977) (Court not deferential to past practices) with Dames \& Moore v. Regan, 453 U.S. 654 (1981) (Court deferential to custom) and Haig v. Agee, 453 U.S. 200 (1981) (Court deferential to custom). See generally Glennon, The Use of Custom in Resolving Separation of Powers Disputes, 64 B.U.L. REv. 109 (1984). (1986).

84. Myers v. United States, 272 U.S. 52 (1926); Bowsher v. Synar, 106 S. Ct. 3181

85. Myers, 272 U.S. at 176.

86. Id. at 170 .

87. Id. at 135 . 
contrasted with purely executive functions. ${ }^{88}$ Most recently, the Court's decision in Bowsher v. Synar ${ }^{89}$ strongly confirmed the Myers rule by striking down the delegation of budget-cutting authority to the Comptroller General under the Gramm-Rudman deficit control law. The Court viewed even the rather technical and highly circumscribed duties of the Comptroller General under this law as "plainly entailing execution of the law in constitutional terms." 90 Accordingly, the Court ruled that budget-cutting functions could not be delegated to an officer like the Comptroller General, who is subject to removal by Congress rather than the president. ${ }^{91}$

Where Myers and Synar struck down limitations on the president's

88. In Humphrey's Ex'r v. United States, 295 U.S. 602 (1935), the Court limited the reach of the Myers ruling when it held that Congress could impose limitations on the president's power to remove a member of the Federal Trade Commission ("FTC"). The Federal Trade Commission Act provides that commissioners "may be removed by the President for inefficiency, neglect of duty or malfeasance in office." 15 U.S.C. $\S 41$ (1982). The Court held that the president's removal power could indeed be restricted to these causes in regard to FTC commissioners, notwithstanding language in Myers suggesting that the presidential removal power must remain entirely unfettered. In distinguishing Myers, Humphrey's Executor stressed the quasi-judicial duties of the FTC and noted that the commissioners were not expected to exercise the general policy discretion entrusted to executive officials. The Court saw an FTC commissioner as "charged with the enforcement of no policy except the policy of the law," Humphrey's Ex'r, 295 U,S. at 624, and accordingly concluded that a commissioner is "an officer who occupies no place in the executive department and who exercises no part of the executive power vested by the Constitution in the President." Id. at 628 . This reasoning was subsequently invoked in Wiener v. United States, 357 U.S. 349 (1958), in which the Court held that the quasi-judicial duties of the War Claims Commission implied a congressional intention to limit presidential removal power that, under these circumstances, was constitutional.

But the continuing validity of Humphrey's Executor is no longer so clear, at least as it applies to officers, like the members of "independent" regulatory commissions, who exercise powers beyond those of a quasi-judicial adjudicator. The district court ruling in Bowsher v. Synar expressly questioned the continuing validity of Humphrey's Executor, and the Supreme Court in Synar did not directly repudiate this aspect of the lower court decision. See Synar, 106 S. Ct. at 3185, 3188-89. But see Ameron, Inc. v. United States Army Corps of Eng'rs, 787 F.2d 875, 885-86 (3d Cir. 1986) (explicitly repudiating the district court in Synar).

On the other hand, the Supreme Court decision in Synar raised different questions about the significance of Humphrey's Executor. In Synar, the Court treated the Comptroller General as an officer under the control of Congress, even though Congress may not (under the relevant statutes) remove the Comptroller at will, but only for "specified cause" (an arrangement that seems exactly parallel to the president's relation to "independent" regulatory commissioners). Synar, 106 S. Ct. at 3189-91. The Court noted that in Humphrey's Executor President Roosevelt had not claimed to be removing Commissioner Humphrey for one of the specified causes of removal. Id. at 3190 n.8. The Court seemed to suggest that, had the president couched his decision to dismiss FTC Commissioner Humphrey in one of these statutorily approved terms, the removal could not have been effectively challenged. At the least, the Court depicted the parallel removal power of Congress over the Comptroller General as effectively unconstrained, Id. at 3190. For a recent academic defense of this position, see Strauss, The Place of Agencies in Government: Separation of Powers and the Fourth Branch, 84 Colum. L. REv, 573 (1984); see also Verkuil, The Status of Independent Agencies After Bowsher v. Synar, 1986 DUke L.J. 779 (suggesting that "for cause" removal limitations might well protect article II policymaking direction). For a more thorough critique of Humphrey's Executor, see Miller, Independent Agencies, 1986 Sup. CT. Rev. 41.

89. 106 S. Ct. 3181 (1986).

90. Id. at 3192 .

91. $I d$. 
removal power, the Court's 1976 ruling in Buckley $v$. Valeo ${ }^{92}$ affirmed the president's constitutional power to appoint administrative officers. Buckley struck down certain provisions in the Federal Election Campaign Act. These provisions vested the appointment of two of the six members of the Federal Election Commission ("FEC") in the President pro tempore of the Senate and the appointment of two other members in the Speaker of the House. Buckley ruled that these provisions violated the express requirement in article II, section 2 of the Constitution vesting the appointment of "all ... Officers of the United States" in the President or in presidentially appointed "Heads of Departments." 93 The Court's decision readily conceded that Congress was entitled to appoint officials charged with the sort of investigative or advisory responsibilities that might otherwise be assumed by congressional committees. But the Court noted:

[The commission's] wide-ranging enforcement power, exemplified by its discretionary power to seek judicial relief, is authority that cannot possibly be regarded as merely in aid of the legislative function of Congress. A lawsuit is the ultimate remedy for a breach of the law, and it is to the President, and not to Congress, that the Constitution entrusts the responsibility to "take Care that the Laws be faithfully executed." 94

The Court concluded that the "administrative functions" of the FEC could "be exercised only by persons who are "Officers of the United States" " and are appointed in the manner the Constitution prescribes for such officers. ${ }^{95}$

These recent decisions clearly establish that Congress may not delegate executive functions to officials who are under congressional, and not executive, control. Even presidential consent to such delegation of authority cannot cure the underlying constitutional infirmity. The Court's decisions leave open the possibility that Congress may constitutionally delegate executive functions to persons who are altogether removed from the control secured by the presidential appointment and removal powers, so long as such persons are equally removed from congressional control, as might be the case with officers appointed by (or answerable to) the courts. ${ }^{96}$ But there are strong reasons to think

92. 424 U.S. 1 (1976) (per curiam).

93. U.S. ConsT. art. II, $\S 2$.

94. Buckley, 424 U.S, at 138 (citing U.S. Const. art. II, § 3).

95. Id. at 141.

96. Congress considered such an arrangement for judicial appointment of federal prosecutors when it established the federal judicial system in 1789. Notably, however, Congress did not finally adopt this arrangement. Instead, Congress left the power to appoint and remove federal attorneys to the president. See Warren, New Light on the History of the Federal Judiciary Act of 1789, 37 HARv. L. REv. 49, 108-09 (1923). While the Court's recent decisions do not clearly prohibit such an arrangement, the rationales relied upon in these opinions raise serious doubts about its constitutional validity. Arrangements that vest powers in officials who are appointed by the president but are protected against presidential removal except for specified reasons raise further constitutional questions which have been examined by recent commentary and decisions. See note 88 supra. 
that Congress may not constitutionally delegate broad executive powers either to the judiciary or to private parties, and that the executive may not make such delegations or subdelegations when not specifically authorized by Congress.

To begin with, the separation of powers arguments advanced by the Court in recent decisions do not refer simply to the division between legislative and executive powers. The Court has stated that " $[t]$ he Constitution sought to divide the delegated powers of the new Federal Government into three defined categories, Legislative, Executive, and Judicial ..."97 and "this system of division and separation . . . was deliberately so structured to assure full, vigorous and open debate on the great issues affecting the people and to provide avenues for the operation of checks on the exercise of governmental power." 98 Plainly, both the constitutional emphasis on tripartite division of the federal government and the delicate balance it creates would be seriously undermined by arrangements blurring the line between executive and judicial powers. At the very least, the delegation of executive functions to the judiciary obscures the parameters of executive discretion in the implementation of the laws. As the Court noted in Synar, it was precisely this concern that James Madison emphasized when he argued against involving Congress in executive branch removals lest this "diminish the responsibility we have in the head of the Executive." 99

On these grounds, we argue that the Constitution prohibits Congress from entrusting the appointment and removal of executive officials to officers outside of the executive branch, including article III judges. ${ }^{100}$ But whether or not this conclusion is correct, judges who undertake such "administrative" duties are not exercising the "judicial power" conferred by article III of the Constitution because article III, by its express terms, limits the judicial power to the adjudication of actual legal cases or controversies. ${ }^{101}$ Where judges are exercising their article III powers (that is, where judges are indeed acting as judges and not as extraordinary administrative officials pursuing some highly unusual administrative assignment) ${ }^{102}$ the article III jurisdic-

97. Chadha, 462 U.S. at 951.

98. Synar, $106 \mathrm{~S}, \mathrm{Ct}$, at 3187.

99. Id. (quoting 1 ANNALS of Congress 380 (1789)); $c f$. Young v. United States ex rel. Vuitton et Fils S.A., 107 S. Ct. 2124, 2148 (1987) (Scalia, J., concurring) (arguing that judicial power cannot extend to law enforcement activities, and therefore federal judges lack the potwer to appoint special prosecutors to investigate contempt charges).

100. This conclusion is one of the central points at issue in current challenges to the constitutional validity of the Ethics in Government Act, providing for the judicial appointment and removal of "special counsels" to investigate and prosecute criminal charges against government officials. See note 155 infra.

101. U.S. ConST. art. III, \& $2, \mathrm{cl} .1$.

102. Judges have, in fact, performed administrative duties altogether removed from their exercise of "the judicial power." For example, Chief Justice Earl Warren served as chair of a nonjudicial investigation into the assassination of President Kennedy. Justice Robert Jackson served as chief United States prosecutor at the Nuremberg War Crimes Trial. In Hayburn's Case, 2 U.S. (2 Dall.) 409 (1792), the Justices of the Supreme Court refused to pass 
tional limitation ensures that judges cannot intrude significantly upon the implementation of those statutory responsibilities that have ordinarily been entrusted to the executive. Beginning with some of the Supreme Court's earliest decisions, federal courts have acknowledged that article III precludes them from offering advice or direction to executive officials on the executive's duties under the law, apart from what is necessary for the resolution of actual disputes ${ }^{103}$ between parties with genuinely adverse claims ${ }^{104}$ in circumstances where the judicial decision is binding on both parties. ${ }^{105}$ This constitutional limitation is an important barrier to excessive judicial involvement in executive decisionmaking. ${ }^{106}$

But this jurisdictional barrier against judicial involvement necessarily falls when an outside party raises a justiciable claim against the government regarding his own legally protected rights or interests. Congress may invest private parties with new and enforceable claims against the government, as when legislation creates financial benefits or entitlements and a right of action against the executive to insure the receipt of those benefits. ${ }^{107}$ Similarly, there is no doubt that executive officials can create judicially enforceable claims in some circumstances, as when the president grants a pardon, ${ }^{108}$ or when an executive agency

judgment on pension claims in their judicial capacilies where the statutory scheme would have made their judgments merely advisory, although they agreed to offer advice in a nonjudicial capacity.

103. "Congress may not, of course, require this Court to render opinions in matters which are not 'cases or controversies.'" Buckley, 424 U.S. at 11. Chief Justice John Jay inaugurated the rule against advisory opinions in 1793 when he declined President Washington's request for guidance on the construction of a treaty outside the context of a particular case. See 3 H. Johnston, The Correspondence and Public Papers of John Jay 489 (1891) (Letter from the Supreme Court to President Washington, Aug. 8, 1793), reprinted in P. BATOR, P. Mishikin, D. Shapiro \& H. Wechsler, The Federal Courts and the Federal System 65-66 (1973).

104. In "the absence of a genuine adversary issue between the parties ... a court may not safely proceed to judgment...." United States v. Johnson, 319 U.S. 302, 304 (1943).

105. The requirement of judicial finality was first emphasized in Hayburn's Case, 2 U.S. (2 Dall.) 409 (1792), in which the Court noted the impropriety of offering judicial determinations of pension claims that could subsequently be reconsidered by the Secretary of War or revised by Congress. The Court's reasoning then and since has been that a non-final judicial determination is no more than an advisory opinion.

106. For a recent restatement of the importance of article III limitations for the preservation of the constitutional separation of powers, see Scalia, The Doctrine of Standing as an Essenlial Element of the Separation of Powers, I7 Suffolx U.L. REv. 881 (1983). But see Nichol, Abusing Standing: A Comment on Allen v, Wright, 133 U. PA, L. REv. 635, 645 (1985) ("Separation of powers analysis simply cannot be applied to current standing doctrine requirements.").

107. We have become so accustomed to judicial review of decisions disallowing or rescinding financial entitlements that it is useful to recall that even in this context questions were once raised about the constitutional propriety of the procedure. See Decatur v. Paulding, 39 U.S. (14 Pet.) 497 (1840) (particularly the concurring opinion of Catron, J. at 518-19). Even today, Congress sometimes precludes judicial revies of administrative determinations of eligibility for financial benefits, as with the determinations of the Veterans Administration. See, e.g., 38 U.S.C. $\$ 211$ (a) (1982).

108. See United States v. Klein, 80 U.S. (13 Wall) 128 (1872) (holding that no legislation can constitutionally direct courts to ignore the effect of a presidential pardon). 
signs a valid contract. ${ }^{109}$

If there were no limit on the creation of new claims against government, however, then vast areas of government responsibility might be transferred to private claimants, subject only to such restrictions as courts might devise from case to case in enforcing such claims. The excessive judicial role invited by these claims would be the least important objection to them. Most fundamentally, such claims raise questions about the delegation of governmental authority to private parties.

Consider, for example, a statutory scheme authorizing "trade or industrial associations ... to enact the laws they deem to be wise and beneficent for the rehabilitation and expansion of their trade or industries."110 The Supreme Court dismissed such a scheme as "utterly inconsistent with the constitutional prerogatives and duties of Congress" 111 and subsequently reaffirmed that "delegation ... to private persons" is "legislative delegation in its most obnoxious form ...."112 Where Congress has instead vested responsibility in an executive program, directly parallel constitutional objections would surely apply to any effort to subdelegate this executive responsibility to private parties. Further, where statutes have vested decisionmaking responsibility in the executive, transfer of this discretion elsewhere would flout the assignment of responsibility in these statutes as well as in the

109. Contract claims are judicially enforceable only insofar as Congress has waived sovereign immunity to allow the courts to review such claims. "The rule that the United States may not be sued without its consent is all embracing." Lynch v. United States, 292 U.S. 571, 581 (1934). However, Congress may waive sovereign immunity and authorize executive agencies to make judicially enforceable contracts. "The United States are as much bound by their contracts as are individuals. If they repudiate their obligations, it is as much repudiation, with all the wrong and reproach that term implies, as it would be if the repudiator had been a State or a municipality or a citizen." Sinking-Fund Cases, 99 U.S. 700, 719 (1879). Thus, for example, the Supreme Court refused to allow the government to repudiate land purchase contracts and stressed: "It is a matter of public importance that good faith contracts of the United States should not be lightly invalidated." Muschany v. United States, 324 U.S. 49, 66 (1945).

110. A.L.A. Schechter Poultry Corp. v. United States, 295 U.S. 495, 537 (1935).

111. Id.

112. Carter v. Carter Coal Co., 298 U.S. 238, 311 (1936). Although the continuing validity of the nondelegation doctrine has been questioned by some judges and commentators, others claim that it still has some force and it has occasionally been advanced as the basis for decisions. See, for example, the express reliance on Schechter Poultry Corp in the Supreme Court's decision in National Cable Television Ass'n v. United States, 415 U.S. 336, 342 (1974), and the respectful reliance by Justice Stevens in Industrial Union Dep't v. American Petroleum Inst., 448 U.S. 607, 647 (1979). Moreover, the particular evil of delegation to private parties, emphasized by the Court in Schechter Poultry Corp. and Carter Coal Co., still elicits serious attention from modern courts. Thus, for example, in Amalgamated Meat Cutters and Butcher Workmen v. Connally, 337 F. Supp. 737 (D.D.C. 1971), one of the most widely cited modern treatments of the nondelegation doctrine, a federal district court upheld a plan for national price control legislation in the face of a constitutional challenge. But the court emphasized that the legislation under challenge did not involve the "kind of delegation of govermment power to private groups that was involved in Schechter." Id. at 763. Further, the court noted in dictum that the price control legislation could not be construed as an open authorization for the president to "delegate authority to persons who are not, at least pro tanto, part of a government agency...." Id. 
Constitution. ${ }^{113}$

Yet if the executive were free to create privately enforceable claims of any scale or scope against government operations, the type of transfer described above could readily result. Consider, as an extreme example, a contract by which an executive agency pledged to be guided in all its decisions by the advice of private consultants. ${ }^{114}$ If courts could enforce such a contract, then the agency could indeed be compelled to transfer all of its decisional authority to a private party or to a court acting on behalf of a private party. The ultimate consequence would be quite bizarre: Although even Congress may not prohibit the president from exercising some influence on an agency's discretionary judgments (as the Supreme Court's recent decisions affirm), the agency could, by contract, exclude any opportunity for presidential influence over its decisions-and then have this exclusion enforced by the courts.

Of course, this result would be precluded by the doctrines in federal contract law reviewed above. But considering such an extreme case in this larger context illustrates that limitations on the enforceability of government contracts are simply particular instances of more general limitations on the delegation or subdelegation of constitutional responsibilities from their proper constitutional channels. ${ }^{115}$ Viewed in this context, the contract cases suggest a theory of constitutional limitations on executive consent decrees.

\section{Toward a General Theory of Constitutional Limitations}

The Court's recent decisions in separation of powers cases suggest that Congress may not delegate executive functions (i.e., functions involving discretionary executive judgments) to officials altogether beyond the influence of the presidential appointment and removal powers. And, as noted above, ${ }^{116}$ there is an even stronger constitutional argument that where Congress has vested responsibility for certain decisions in the executive, the executive may not redelegate this authority to private parties.

These are rather formal principles, subject to numerous objections

113. Presidential reorganization schemes, where authority is transferred from one agency to another within the federal government, for example, have required explicit congressional authorization. Even where cabinet secretaries have tried to delegate decisionmaking responsibility within their own departments, courts have raised serious questions about such practices. The courts have held that where a statute vests ultimate decisional responsibility in the department secretary the secretary cannot delegate this authority. See Morgan v. United States, 304 U.S. 1, 3-4 (1938); KFC Nat'l. Management Corp. v. NLRB, 497 F.2d 298 (2d Cir. 1974), cert. denied, 423 U.S. 1087 (1976).

114. See, for example, Weinberger v. Hynson, Westcott \& Dunning, Inc, 412 U.S. 609 (1973), in which the Court affirmed that the Food and Drug Administration could not rely solely upon the recommendations of scientific advisory panels in carrying out its statutory responsibility to determine the efficacy of prescription drugs, where the petitioner satisfied a minimum threshhold of prima facie evidence of efficacy.

115. See note 112 supra.

116. See note 113 supra. 
when viewed from the more "realistic" perspective of traditional practice. When a federal prosecutor strikes a plea bargain, for example, he or she is effectively yielding some prosecutorial discretion to the defendant. ${ }^{117}$ Yet such agreements are not considered nonbinding. When executive agencies sign contracts with suppliers of goods and services, these agencies are, in a literal sense, forfeiting to private parties some of the spending discretion they would otherwise retain. But again, such authorized financial contracts are not considered unenforceable by virtue of these negotiated limitations on executive discretion.

If the formal principle prohibiting the delegation of government authority to private parties has any force, we must be able to draw a line between acceptable and unacceptable forms of delegation. The problem is parallel to the question raised by the limits on the obligation of government contracts, or by the doctrine of sovereign breach in federal contract law. If all contracts with government could be enforced, then state governments might bargain away their police powers, and the federal government might be compelled to withhold the exercise of its sovereign power. To avoid these results, the Supreme Court has prohibited state legislatures from making binding commitments not to exercise their general regulatory powers. ${ }^{118}$ At the federal level, executive agencies are similarly without power to make binding commitments not to exercise their basic policy prerogatives. ${ }^{119}$ Executive officials are also without power to make unauthorized spending or enforcement/ nonenforcement commitments.

By analogy with the contract cases, and by extrapolation from the presidential power cases, we argue that courts should recognize the following three limitations on the permissible scope of consent decreeslimitations upon which we will elaborate in the next section. First, the executive branch cannot bind itself (or subsequent administrations) on its legislative recommendations to Congress because these represent a broad political responsibility directly rooted in the Constitution. Second, while the executive may commit available funds to particular projects authorized by Congress, it may not commit itself to dispense funds not yet authorized or appropriated by Congress because such action would preempt broad congressional policy prerogatives. Third, the executive branch may make binding offers of immunity to potential criminal defendants in particular cases or limit the reach of its regulatory demands on a temporary basis. But it may not permanently bind its own general enforcement discretion (or that of subsequent administrations) any more than it may delegate its decisional authority to nongovernmental bodies by contract.

117. See note 74 supra.

118. See notes 51-53 supra and accompanying text.

119. See notes 59-61 supra and accompanying text. 
These limitations on delegations of power by the executive are rooted in fundamental constitutional principles. They are, in the first instance, limitations on the executive. Where they apply, however, they must also be binding on the judiciary, because courts are bound to uphold such limitations on the executive power. This reasoning remains unaffected by the recent holding in Cleveland Firefighters. ${ }^{120}$ For even if, as this holding suggests, statutory limitations on judicial authority do not always require parallel limitations on the authority of courts to enter or enforce consent decrees, the courts may not allow the executive to do through the medium of consent decree what the executive could not properly do otherwise.

Courts may have erred by inadvertently entering decrees that promise more than the executive has the constitutional authority to promise. Such mistakes are rather easily made when neither party to the agreement has any incentive to remind the court of the limitations involved. But where such mistakes are made, it is compounding error for courts to enforce the agreement when the executive seeks to repudiate the decree and reassert its independent constitutional responsibility for making public policy. The best way to minimize the unfairness of the repudiation to the other party is to make clear in advance which kinds of government commitments will not be enforceable.

\section{Executive Responsibilities That May Not be BargaINed AWAY}

"Executive power" is the power to execute the laws. This power may seem inherently subordinate to the legislative power, the power to make and unmake the laws, including the laws that finance executive operations. ${ }^{121}$ The executive power may also seem subordinate to the judicial power, insofar as the judicial power is conceived as the power

120. See notes 28-31 supre and accompanying text.

121. As Locke stated: "[T] he legislative is the Supreme Power. For what can give laws to another must needs be superior to him ...." Locke, An Essay Concerning the True Original Extent and End of Civil Government, in Social ConTract 88 (1960) (3d ed. 1698). Locke, however, advanced broad claims for independent executive action in identifying a residual power in the executive "to act according to discretion, for the public good, without the prescription of the law...." Id. at 95. Madison, in the Federalist No. 51, acknowledged forthrightly that "[i]n republican government, the legislative authority necessarily predominates" but went on to urge the importance of constitutional guarantees of executive independence. THE FEDERALIST No. 51, at 322 (J. Madison) (C. Rossiter ed. 1961). As a practical matter, executive power in the British monarchy was, by the eighteenth century, broadly accountable to the House of Commons because the Commons retained the power of the purse. The Founders were well aware of both the strength and source of this parliamentary power. The Constitution's prohibition against diminishing or increasing the chief executive's salary during the presidential term, U.S. ConST. art. II, \& 1, cl. 7, was devised to prevent the most blatant kind of fiscal assault on executive independence. But legislative control over appropriations obviously continues to provide a very potent mechanism for influencing and restricting the activities of executive departments because the departments have no similar protection against having their appropriations reduced or restricted. 
to "say what the law is." 122 But the Constitution plainly reserves a substantial independent role for the executive.

Statutes may define and direct particular executive duties in considerable detail, but there usually remains substantial discretion between statutorily conferred powers and statutorily required actions. In some areas, the Constitution ensures that some discretion will remain, as the prohibition on bills of attainder in article $\mathrm{I}^{123}$ and the due process guarantee of the fifth amendment ${ }^{124}$ preclude overly particularized enforcement directives. The Constitution also provides a far broader, if more indirect, protection for executive discretion by giving the president a significant role in the legislative process. ${ }^{125}$ Once laws are duly enacted, the Constitution provides safeguards for their independent execution by requiring that at least the "heads" of executive "departments" be appointed by the president ${ }^{126}$ and that the power of removing executive branch appointees remain with the president or the

122. The phrase is, of course, from Marbury v. Madison, 5 U.S. (1 Cranch) 137, 177 (1803), a case that dealt with judicial control over executive conduct. In fact, President Jefferson, who criticized Marbury's assertion of the power of courts to review the constitutionality of legislative enactments, was equally critical of Marbury's claim to bind the executive to judicial interpretations of the law. President Jefferson's view, although not altogether implausible in itself, would have implied a very different system than the one we have chosen. See XII THE Works of Thomas JEFFERSon 138-39 (P.L. Ford ed. 1905). See generally Monaghan, Marbury and the Administrative State, 83 CoLUn. L. REv. 1 (1983).

123. U.S. CoNST. art. I, $\S 9, \mathrm{cl}$. 3. Taken literally, the prohibition on bills of attainder might be regarded as prohibiting only a legislative enactment specifying a particular penalty for a particular person, but not perhaps an enactment directing the executive to prosecute a particular offender through the courts. But even the lesser expedient of directing the executive to withdraw financial benefits from a restricted class of persons has been treated as the constitutional equivalent of a bill of attainder. See United States v. Lovet, 328 U.S. 303, 315 (1946).

124. U.S. ConST. amend. V, cl. 3. The due process guarantee of the fifth amendment has been understood to contain an equal protection component, prohibiting legislation that singles out identified groups even for purposes of restricting funding. See, e.g., United States Dep't of Agric. v. Moreno, 413 U.S. 528, 533 (1973). There is an even stronger argument for applying this reasoning to protect narrow groups from being singled out for prosecution.

125. The most important guarantee of presidential influence in the legislative process is, of course, the president's qualified veto power, U.S. ConsT. art. I, \$ 7, cl. 3. Alexander Hamilton defended this provision by emphasizing the "propensity of the legislative department to intrude upon the rights and to absorb the powers of the other departments" and the consequent "necessity of furnishing each [department or branch of the government] with constitutional arms for its own defense." THE FEDERALIST No. 73, at 442 (Hamilton) (Rossiter ed. 1961). Without a veto potver over legislation, the president "might gradually be stripped of his authorities by successive resolutions or annihilated by a single vote." Id. But the same discussion goes on to note that the veto power "not only serves as a shield to the Executive, but it furnishes an additional security against the enactment of improper laws" and is "calculated to guard the community against the effects of faction, precipitancy, or of any impulse unfriendly to the public good which may happen to influence a majority" in Congress. Id. at 443.

126. "Officers of the United States" are made subject to confirmation by the Senate, while the appointment of "inferior Officers"-a term not defined-may be vested directly and entirely "in the President alone, in the Courts of Law, or in the Heads of Departments," as "Congress may by law" determine. U.S. Const. art. II, $\$ 2, \mathrm{cl}$. 2. While Congress may not directly participate in these appointing powers, statutes have often limited eligibility for appointment by imposing certain required qualifications. Whether it is constitutional for Congress to impose such statutory limitations on nominees to be "Officers of the United States" is 
president's subordinates. ${ }^{127}$ Finally, while the scope of executive discretion under any particular statute may be restricted by judicial construction of ambiguous statutory provisions, the Constitution assures that the judiciary cannot exercise an unlimited supervisory authority over executive operations by restricting the judicial power to actual cases or controversies presenting justiciable questions of law. ${ }^{128}$

The executive power conferred by the Constitution is thus a complex hybrid, in some respects definitely subordinate to other powers, in other respects emphatically independent. Paradoxical as it may seem, it is the subordination of the executive as much as its independence that requires definite limits on the extent to which the executive may cede its own discretion in consent decrees. These limits are easier to discern if executive power is examined in its different contexts.

\section{A. Legislative and Budgetary Recommendations}

The Constitution guarantees the president a large role in legislative decisionmaking (including decisionmaking on appropriations). In the first place, the Constitution requires that the president "give to the Congress Information of the State of the Union and recommend to their Consideration such Measures as he shall judge necessary and expedient , . ."129 More importantly, the Constitution gives the president a qualified veto over legislation, ${ }^{130}$ allowing the president to force Congress to pay heed to the president's views on what is unnecessary or inexpedient. As the president's veto power is coextensive with the congressional power to legislate, the power to "recommend" must be equally sweeping. The Framers clearly regarded these separately enumerated powers as mutually supporting aspects of an ongoing legislative role for the president. ${ }^{131}$

perhaps a moot point given the Senate's power to refuse its consent for such appointments on a case-by-case basis.

127. Myers v. United States, 272 U.S. 52, 173-74 (1926); Bowsher v. Synar, 106 S. Ct. 3188 (1986) (emphasizing that Congress may not participate in the removal of executive officers except by impeachment).

128. See notes 103-106 supra.

129. U.S. ConsT. art. II, \& 3.

130. U.S. ConsT. art. I, \& 7, cl. 3.

131. Even the spare text of the Constitution suggests the connection between the president's veto power and the more general presidential power to advise Congress on legislation. Article I, section 7 presents the veto power not as a mere mechanical obstacle, but quite specifically as a device for highlighting presidential policy views on emerging legislation: If the president does not "approve" a bill passed by Congress, the Constitution directs that "he shall return it, with his Objections, to that House in which it shall have originated, who shall enter the Objections at large on their Journal, and proceed to reconsider it." U.S. ConST. art. I, $\S 7$, cl. 2. The Constitution does not require the president to propose specific legislative alternatives where he does not "approve" a bill as submitted, but many of the Framers plainly hoped the veto power would guarantee the president a substantial advisory role in legislative deliberation and drafting.

The presidential veto power, as it now appears in the Constitution, is the institutional residue of a more ambitious proposal, repeatedly urged by Madison, Wilson, and other leading figures at the Constitutional Convention, to associate the president with several members 
INS $v$. Chadha ${ }^{132}$ establishes that the president's power to influence Iegislative policy is coextensive with the congressional power to legisIate. In Chadha, the Supreme Court struck down the legislative veto provision in the Immigration and Nationality Act of $1952 .{ }^{133}$ This provision purported to grant either house of Congress the authority to

of the judiciary in a "Council of Revision" to urge changes in legislative bills. On the appeal of this proposal, see C. Thach, THE CREation of the PRESIDENCY, 1775-1789, at 40, 81-90, $125-27,171-73$ (1969). This scheme was finally rejected for involving the judges too closely in policy matters. But Elbridge Gerry captured some of the hopes behind this proposal in urging an alternative approach less vulnerable to this charge: "A better expedient for correcting the laws would be to appoint .... a person or persons of proper skill to draw bills for the Legislature." II M. FARRAND, THE Records OF THE FEdERAL Convention of 1787, at 75 (1937).

Article II, section 3 mentions the president's authority to recommend measures to Congress immediately after assigning to the president the duty to give information on the state of the union. But this juxtaposition was not intended by the Framers to limit the presidential power to recommend measures to the context of giving information on the state of the union. In earlier drafts of the Constitution, these presidential responsibilities were actually conferred by two distinct clauses, separated by a semicolon, with the discretionary character of the power to "recommend" emphasized by the separate wording "he may recommend." See id. at 185. The current wording was proposed by Gouverneur Morris, persistent advocate of a stronger executive power, "in order to make it the duty of the president to recommend, \& thence to prevent umbrage or cavil at his doing it." Id. at 405 (emphasis in original). THE FEDERALIST No. 77, at 463 (Hamilton) (Rossiter ed. 1961), returned to listing these as separate "powers of the executive ... comprehended in giving information to Congress of the state of the Union; in recommending to their consideration such measures as he shall judge expedient ...." President Washington began the custom of serving the constitutional duty to "give to Congress Information of the State of the Union" with a special, formal address at the end of each year. But Washington's First Inaugural spoke of "the duty of the President to recommend ... such measures as he shall judge necessary and expedient," without referring to the giving of "information of the State of the Union." I RichaRdSON, A COMPILATION OF the Messages and Papers of the Presidents 52 (1896). And President Washington did not hesitate to recommend measures to Congress outside the context of his annual address on the state of the union. See, e.g., id. at 60 (urging legislation to establish "some uniform and effective system for the militia"); id. at 149 (urging legislation to establish a special office for public supplies in the War Department).

Thach's study of the original constitutional debates on the presidency concluded that most of the Framers held to a "latitudinarian view of the President's veto power" because they hoped the president's legislative role would help "to prevent the enactment of unwise policies." And "[e]ven with respect to the President's positive power to initiate legislation [by exercising his power to recommend], there is no reason to believe," Thach concluded, "that the same liberal interpretations [of presidential authority] were not held by many." Thach, sufira at 171-72. The Supreme Court's Chadha decision suggests that the presidential veto power must be coextensive with the congressional power to legislate. Giving a narrower scope for the power to recommend than for the qualified veto power would invite the bizarre conclusion that the president may veto any bill that emerges from Congress, but may not always give Congress advance waming of an intention to veto, or may not always try to forestall a veto by proposing better alternatives. Giving a narrower scope to the power to recommend than to the power to veto also appears to reverse the nearly universal estimate of the relative importance of these powers at the time of the ratification debates. The presidential veto power was much criticized by opponents of the Constitution. But, regarding the power to recommend, as THE FEDERALIST No. 77 noted, "no objection has been made ...." THE Federalist No. 77, at 463 (Hamilton) (Rossiter ed. 1961). We find it difficult to conceive of the reasoning that would restrict the power to recommend, which "could [not] possibly admit of any [objection]," $i d$, while conceding that the weightier and more controversial veto power must remain unfettered.

132. 462 U.S. 919 (1983).

133. Immigration and Nationality Act $\$ 244$ (c)(2), 8 U.S.C. § 1254(c)(2) (1982). 
overrule decisions of the Attorney General suspending individual deportation orders of the Immigration and Naturalization Service. The constitutional Haw in this arrangement, the Court explained, was that congressional resolutions were accorded the force of law-in this case, compelling the deportation of particular aliens-without opportunity for a presidential veto, ${ }^{134}$ Even though the congressional determinations involved were as narrow in focus as the fate of particular individuals, the Court held that the president must be afforded an opportunity to exercise a veto over these determinations.

If the president's veto power must remain unfettered, even down to this level of detail, then his power to "recommend" must remain equally unfettered. Put otherwise, if the president may not "bargain away" his veto power to Congress even on such particularized determinations, it is hardly conceivable that he may "bargain away" his power to recommend. It then must follow that consent decrees can never bind the president's power to veto or to recommend legislative measures, for the president's subordinates in the executive branch cannot

134. Chadha, 462 U.S. at $952-54$. The violation of the constitutional requirement that bills be "presented to the President" for approval was not the Court's only objection to the legislative veto provision at issue in Chadha. The Court also found fault with the arrangement for violating the requirement that bills be enacted by both houses of Congress before assuming the force of law. Id. at 948-51. But the decision affords no basis for the supposition that the Court was less concerned about the presentment requirement than the bicameralism requirement. On the contrary, the Court emphasized the president's distinctive claims to participation in the legislative process. It noted that the Framers "considered" the presentment requirement to be "so imperative that [they] took special pains to assure [it] could not be circumvented." Id. at 947. And the Court took "special pains" of its own to defend this requirement. Rather than depicting the presentment requirement as merely another mechanical obstacle to impulsive legislative action, akin to the requirement for bicameral agreement, the Court described presentment of bills to the president as a device to "serve the important purpose of assuring that a 'national' perspective is grafted on the legislative process ... [because] 'at some times, on some subjects .... the President elected by all the people is rather more representative of them all than are the members of either body of the Legislature whose constituents are local and not countrywide....' "Id. at 948 (quoting Myers v. United States, 272 U.S. 52, 123 (1926)). Moreover, the Court classified the administrative decisions at issue in Chadha-decisions by the Attorney General to suspend the deportation of particular aliens-as "Executive action" or "the Executive's administration of the laws," disdaining to embrace ambiguous compromise terms like "quasi-legislative." Id. at 953 n.16. This classification of the decisions as "executive" bolstered the Court's claim that the presentment clause was an essential safeguard of executive prerogatives against legislative encroachment. $I d$. at 947. However, this classification complicated the Court's argument that attempts by either house of Congress to overturn a deportation decision were, after all, exercises of legislative power, violating the constitutionally mandated procedure for legislative action.

Curiously enough, even Justice White's dissenting opinion, while seeking to defend the propriety of legislative vetos in some settings, did not treat the presentment issue as secondary or peripheral to the bicameralism issue. Indeed, the dissent suggested that a scheme allowing Congress to veto executive actions by the concurrent resolution of both houseswhich would seem to satisfy the bicameralism objection-would not be more constitutionally acceptable than a one-house veto arrangement, but actually less so. Id. at 997 (White, J., dissenting). See also Fellows, Congressional Oversight Through Legislative Velo After INS v. Chadha, 69 CoRNELL L. REv. 1244, 1255-58 (1984) (student author) (arguing that presentment holding is central to Chadha ruling). 
bargain away a presidential prerogative which the president cannot bargain away.

Does this mean that the president remains free to exercise his veto power or his power to recommend legislation even with the specific aim of creating obstacles to the implementation of a particular consent decree? The answer must be yes. A legislative measure with no other purpose than the restriction of the government's contractual obligations would probably violate the due process clause of the fifth amendment. ${ }^{135}$ In certain rare circumstances, similar constitutional objections might be raised against legislative measures specifically designed to frustrate the implementation of consent decrees. ${ }^{136}$ But even in such cases, the objection would lie against the enacted measure, not against the recommendation or veto of the president. For courts to restrain or coerce the president's role in the legislative process would be as improper as for courts to enjoin the voting of Members of Congress. ${ }^{137}$

The other party to a threatened consent agreement might, of course, try to evade these objections by claiming that the president's leg-

135. Sec note 39 supra.

136. The theory articulated in System Fed'n, see notes 24-27 supro and accompanying text, suggests that there is no difficulty with a legislative measure invalidating a consent decree by altering the statute under which the decree was issued. In general, the other party to the decree seems to have no more right to have the decree protected from legislation that may modify it than to have the underlying statutory policy maintained. But the Supreme Court has sometimes treated the fifth amendment as a guarantee against arbitrary or invidious exclusion by statute from government benefits-even where there is no prior right to such benefits. See, e.g., United States Dep't of Agric. v. Moreno, 413 U.S. 528, 538 (1973) (invalidating statutory exclusion from food stamp eligibility of households with unrelated persons). The interest in maintaining a consent decree, particularly where the other party had made substantial compromises or concessions to obtain the government's agreement to its terms, might be similarly protected, but only against a legislative repeal measure so particular or invidious in its application as to seem altogether arbitrary.

137. Such intervention might breach those protections afforded the president that are akin to congressional immunity under the speech or debate clause of article I. "[F]or any Speech or Debate in either House, [the Senators and Representatives] shall not be questioned in any other Place." U.S. ConsT. art. I, § 6, cl. 1. The Supreme Court has construed this provision to apply to votes as well as verbal statements in debate. Powell v. McCormack, 395 U.S. 486,506 (1969). This guarantee does not directly apply to the president. Because the Constitution gives the president a direct role in the legislative process, however, the Constitution may imply a similar speech or debate immunity for the president. In United States v. Nixon, the Court recognized a constitutional basis for claims of "executive privilege" invoked against efforts to compel courtroom testimony about White House deliberations. 408 U.S. 638 (1974). While the Constitution makes no explicit reference to such "a presidential privilege.... corresponding to the privilege of Members of Congress under the speech or debate clause ...." the Court noted, "the silence of the Constitution on this score is not dispositive." Id. at 705 n.16 (1974). The Court subsequently ruled that the president may not be held to account in civil actions for what he says in private deliberations within the executive branch. Nixon v. Fitzgerald, 457 U.S. 731 (1982). Presidential legislative preferences, particularly on matters of detail, are often conveyed to Congress by individual members, and any presidentially sponsored bill must be submitted by a Member of Congress in order to enter the legislative process. By relying on those constitutional guarantees already confirmed by the Court, the president could convey the executive's legislative preferences to a particular Member of Congress in a private discussion- a discussion protected by the doctrine of civil immunity for presidential deliberations. The member could then introduce the measure into Congress, 
islative action, rather than the ultimate legislative result, constitutes the violation, because only the executive is an actual party to the decree. ${ }^{138}$ But arguments of this sort are tainted with the precise constitutional difficulty identified in Chadha: They envision a legislative process where Congress may act with binding results while the president is prevented from participating in the process. ${ }^{139}$

Consent decrees that pledge the president to act or not to act in particular ways in the legislative process must be void in this respect, because they promise more than the executive has the constitutional power to promise. ${ }^{140}$

\section{B. Spending Authority}

Once an appropriation has been duly enacted, the authority of the executive in expending that appropriation stands on a different constitutional footing. Here, executive policymaking is not coequal with that of Congress, but is largely subordinate. ${ }^{141}$ An appropriation may be

expound at length on the president's rationales, and then claim the legal immunity of the speech or debate clause.

In addition, restraints or coercions relative to the president's legislative involvement may offend the ripeness component of justiciability requirements by addressing a hypothetical injury, because the president's recommendation or veto may not determine the ultimate outcome of legislation. The ripeness component of justiciability is one aspect of the more general prohibition on judicial consideration of abstract or hypothetical questions, a prohibition that has long been treated by the federal courts as a necessary inference from article III's restriction of "the judicial power" to actual cases and controversies. See, e.g., United Public Workers v. Mitchell, 330 U.S. 75, 89-90 (1947) ("The power of courts .... arises only when the interests of litigants require the use of this judicial authority for their protection against actual interference. A hypothetical threat is not enough."). But see Nichol, Ripeness and the Constitution, 54 U. Chr. L. REv. 153 (1987) (arguing for a prudential ripeness test).

138. To the extent that Congress remains free to alter or invalidate consent decrees by altering the statutory provisions under which they were negotiated, Congress may indeed seem not to be bound by government consent decrees and thus not a party to such decrees. See note 136 supra.

139. The actual legislative veto provision struck down in Chadha gave action by only one house of Congress the force of law. But the Court clarified that even action by both houses, where the possibility of a presidential veto was excluded in advance, would be subject to fatal constitutional objection. For elaboration of the claim that the universal applicability of the presentment clause was an essential holding of Chadha, see note 134 supra.

140. Even if one doubts the arguments for an absolute prohibition on enforceable promises of this kind, the constitutional difficulties are great enough to justify judicial refusals to recognize such promises except when clearly and explicitly articulated by a fully authorized representative of the president. Such refusals are in keeping with well-established doctrine in estoppel cases that private parties cannot rely on unauthorized representations of lower officials if these turn out to be contrary to established policy. See notes 71-73 supra and accompanying text. And, consistent with this reasoning, it might be argued that no single president is authorized to speak for later presidents on such matters.

141. After the impoundment controversy of the early 1970s (that is, the events surrounding President Nixon's claim that the executive can refuse to spend appropriated funds if the president judges such refusal to be in the national interest), the Supreme Court emphasized that legislative intent determines whether the executive may withhold appropriated funds. Train v. City of New York, 420 U.S. 35, 41 (1975). In Train, the Court noted that the Justice Department had not tried to argue the contrary constitutional position in this major test case of the Nixon impoundment policy. Instead, the Department had relied on a different interpretation of the relevant funding statutes. The Impoundment Control Act of 1974, Pub. L. 
sufficiently precise and detailed to exclude all executive discretion, leaving the relevant funding agency with a ministerial duty to deliver the funds as directed. ${ }^{142}$

But even here there are important constitutional limitations on the extent to which the executive may bind itself to dispense funds. These limitations derive precisely from the constitutional necessity of subordinating executive operations in this area to legislative policy.

The Constitution specifies that "[n]o money shall be drawn from the Treasury but in consequence of appropriations made by law."143 To safeguard its constitutional control of the federal pursestrings, Congress enacted a statutory prohibition in the nineteenth century against the making of any "contract or purchase on behalf of the United States, unless the same be authorized by law or be under an appropriation adequate to its fulfillment ...."144 The provision is plainly designed to prevent the executive from committing Congress to appropriate funds to redeem unauthorized agreements. Congress recently extended a similar prohibition against involving the federal government in any "obligation for the payment of money before an appropriation is made unless authorized by law." 145

Just as courts cannot enforce unauthorized contracts, consent agreements promising grants or funding without legislative authorization must be void because such agreements would equally compel Congress to appropriate funds against its will. ${ }^{146}$ But what if a funding agreement is simply made contingent on a subsequent appropriation?

Where the executive promises to provide funds only if and when relevant appropriations are approved by Congress, such promises may

No. 93-344, $\$ \S 1001-1017,88$ Stat. 297, 332-39 (1974) (codified as amended at 2 U.S.C. $\$ \$ 681-688$ (1982 \& Supp. III 1985)), imposed time limits and subsequent accountability of the president to Congress for such broad spending decisions. Prior to the excesses of the Nixon Administration, many presidents had asserted a constitutional authority to withhold appropriated funds. The practice had been defended by several commentators, see, e.g., L. Fisher, President and Congress 122-27 (1972); Note, Presidential Impoundment: Constitutional Theories and Political Realities, 61 GEo. L.J. 1295 (1973), and some commentators had even defended impoundment as a necessary constitutional prerogative of the president. See Miller, Presidential Power to Impound Approprialed Funds: An Exercise in Constitutional Decision-making, 43 N.C.L. REv. 502, 533 (1965). The disavowal of this broader spending prerogative since the mid-1970s, however, does not affect the argument for executive spending discretion within the limits laid down by Congress. For further elaboration of Congress' ability to limit executive spending discretion, see Devins, The Regulation of Government Agencies Through Approprialions Riders, 1987 DuKE L.J. - (forthcoming).

142. See Kendall v, United States ex rel. Stokes, 37 U.S, (12 Pet.) 524, 612-13 (1838).

143. U.S. ConST, art. I, $\$ 9$, cl. 7.

144. Act of Mar. 2, 1861, ch. 84, $\S 10,12$ Stat. 214, 220 (current version at 41 U.S.C. \$ 11 (1982 \& Supp. III 1985)),

145. Acc of Sept. 13, 1982, Pub. L. No. 97-258, § 1341, 96 Stat. 877, 923 (codified at 31 U.S.C. $\$ 134$ (1982)).

146. This principle does not apply to authorized proceedings in the United States Court of Claims. The jurisdictional statutes authorizing these proceedings imply advance congressional consent to the payment of such claims, see note 46 supra, and Congress has appropriated funds in advance to a fund for the settlement of these claims. 28 U.S.C. $\$ 2517$ (1982). 
seem to pose no threat to the legislative power of the purse. And, the courts could therefore enforce such a promise without constitutional objection if Congress subsequently enacts the relevant appropriation. Yet suppose that Congress intended the appropriation to cover a large number of projects or programs but full satisfaction of a prior contingent commitment has the effect of excluding most other expenditures because the prior commitment preempts so much of the appropriation. In that case, enforcement of a contingent funding commitment might indeed thwart legislative expectations and thus still threaten legislative control of the federal pursestrings.

The courts need not void all contingent funding commitments $a b$ initio in order to avoid this difficulty. The "sovereign breach" doctrine in federal contract law provides an adequate mechanism to prevent this potential loss of legislative control, assuring that no federal agency may make a binding contract that constrains the government from undertaking "[a]ctions of a general and public character, implementing programs in the national interest . ..."147 Even a funding agency may invoke this doctrine in defense of its residual authority to alter the "general and public" framework of its grant-making policy. If an agency has promised to supply funding to a particular party when appropriations become available, the agency might properly be enjoined from entirely repudiating this particular commitment. But such a contingent commitment could not prevent the agency from altering its general funding policies, even though the policy alteration had the incidental effect of limiting the funds available for that particular commitment. No agency has the constitutional authority to restrict its own ability to alter "general and public" policies.

This distinction is quite important for executive obligations made contingent on future appropriations or authorizations. Although it sometimes authorizes multi-year funding commitments, Congress enacts most appropriations on a year-to-year basis and limits authorizations of funding commitments accordingly. ${ }^{148}$ The size of appropriations may vary from year to year in unpredictable ways and there may be even more unpredictable variance in the costs or needs of the programs involved. Agencies must therefore recalibrate their spending priorities each year to serve congressional expectations. The technical question of whether an appropriation is large enough to cover a particular prior commitment is not the same as the policy question of whether honoring that commitment will leave sufficient remaining funds to accommodate all of the other goals and needs of the program involved at the most appropriate levels of funding. If the executive were forced to honor prior contingent commitments whenever the ap-

147. Wunderlich Contracting Co. v. United States, 351 F.2d 956, 967 (Ct. Cl. 1965).

148. See Fisher, The Authorization-Appropriation Process in Congress: Formal Rules and Informal Practices, 29 CATH. U.L. Rev. 51, 99-102 (1979). 
propriation was technically sufficient, Congress might have to appropriate larger sums than it would otherwise have done-or risk seeing its program expectations frustrated by the diversion of its general appropriation to one or two priority commitments. By acknowledging limits on the enforceability of executive agreements to commit funds, courts would forestall this threat to congressional control of government spending.

\section{Enforcement Discretion}

Compared with the president's participation in the legislative process, enforcement of existing laws by the executive is plainly a subordinate prerogative constrained by what each statute provides. Congress may limit the scope and form of executive discretion in law enforcement, and the Constitution imposes other limitations with the rights it confers on the accused. ${ }^{149}$ An irreducible core of executive independence in the exercise of enforcement discretion nevertheless remains. On the one hand, the president's pardon power ${ }^{150}$ and the prohibition of congressional bills of attainder ${ }^{151}$ assure that prosecution and enforcement in particular cases can never be a purely ministerial duty. On the other hand, enforcement is always a problem of balancing enforcement goals against available resources. While both the goals and the resources are largely determined by Congress, the executive must have flexibility to adapt to changing congressional priorities and changing levels of funding.

The Supreme Court has continued to emphasize the constitutional grounding of executive discretion in law enforcement. In United States $v$. Nixon, the Court insisted that the executive branch retains "absolute discretion to decide whether to prosecute a case," 152 citing earlier decisions tracing prosecutorial discretion to "the constitutional separation of powers." 153 Only evidence of flagrant bias or discrimination in the pattern of prosecution seems to justify judicial review of decisions not to prosecute. ${ }^{154}$

149. For example, the fourth amendment's guarantee against unreasonable searches and seizures, the fifth amendment's requirement of due process, and the sixth amendment's confrontation clause impose significant restraints on the executive's enforcement discretion.

150. U.S. Const. art. II, \$ $2, \mathrm{cl}$. 1. The pardon power may be exercised at any time subsequent to the commission of an offense, even prior to indictment. See Ex Parle Garland, 71 U.S. (4 Wall.) 333,380 (1866).

151. U.S. Const. art. I, $\$ 9$, cl. 3. This clause prohibits legislative enactments that impose penalties-even indirect penalties, like the denial of public employment-on an overly particularized basis. See United States v. Brown, 381 U.S. 437, 441-46 (1965); United States v. Lovett, 328 U.S. 303, 315 (1946); Garland, 71 U.S. at 377.

152. 418 U.S. 683,693 (1974) (citing Confiscation Cases, 74 (7 Wall.) 454 (1868)).

153. United States v. Cox, 342 F.2d 167 (5th Cir. 1965), cert. denied sub. nom. Cox v. Hauberg, 381 U.S. 935 (1965) (tracing prosecutorial discretion to "the constitutional principle of the separation of powers").

154. "The Court's prior decisions consistently hold that a citizen lacks standing to contest the policies of the prosecuting authority when he himself is neither prosecuted nor threatened with prosecution .... [I]n American jurisprudence at Ieast, a private citizen lacks 
Congress can, no doubt, narrow the range of enforcement discretion with more detailed and emphatic statutory standards. But some room for executive judgment and discretion-regarding the sufficiency of evidence, the availability of alternative enforcement mechanisms, the competing claims of other cases on enforcement resources, and so onwill always remain. ${ }^{155}$

This reasoning is not limited to criminal prosecutions. In its 1985 decision in Heckler v. Chaney, the Supreme Court affirmed the Food and Drug Administration's unreviewable discretion to decline to challenge the safety and efficacy of particular drugs. ${ }^{156}$ The Court in Chaney did not hesitate to draw the parallel between these aspects of administrative discretion:

[An administrative or regulatory] agency's refusal to institute proceedings shares to some extent characteristics of the decision of a prosecutor in the Executive Branch not to indict-a decision which has long been regarded as the special province of the Executive Branch, inasmuch as it is the Executive who is charged by the Constitution to "take care that the laws be faithfully executed."157

And, the Court saw parallel practical arguments for "the general un-

a judicially cognizable interest in the prosecution or nonprosecution of another." Linda R.S. v. Richard D., 410 U.S. 614,619 (1973); see also Leeke v. Timmerman, 454 U.S. 83, 86-87 (1981) (per curiam). Discriminatory enforcement policies were relied upon to invalidate a statute in Yick Wo v. Hopkins, 118 U.S. 356 (1886). But, in Doyler v. Boles, 368 U.S. 448, 456 (1962), the Supreme Court held that, in general, "the conscious exercise of some selectivity in enforcement is not in itself a federal constitutional violation." Only where there is evidence that prosecutorial "selection was deliberately based upon an unjustifiable standard such as race, religion, or other arbitrary classification," the Court explained, are there "grounds supporting a finding of denial of equal protection ...." Id.

155. One apparent exception to the general acceptance of executive discretion in criminal prosecutions is presented by the post-Watergate Ethics in Government Act of 1978, Pub. L. No. 95-521, \$601, 92 Stat. 1824, 1867-73 (1978) (codified as amended at 28 U.S.C. $\$ \S 591-598$ (1982 \& Supp. III 1985)). This Act provides for the appointment of special counsel in place of Justice Department officials to investigate and prosecute charges of criminal wrongdoing by government officials. The statutory scheme deliberately places the special counsel beyond the direct or indirect reach of presidential removal power in order to insulate its decisions from executive control. The constitutionality of this arrangement, however, has been questioned by former Attorney General Griffin Bell, as well as by the current Justice Department, and is currently the subject of litigation. See Hearings Before the House Judiciany Subcommittee on Extension of the Ethics in Government Act, 100th Cong., 1st Sess. 1987. The measure as currently crafted is not a complete contradiction of the larger principle of executive discretion in criminal prosecution policy. The District of Columbia Circuit refused in a recent case to allow judicial review of the Attorney General's exercise of discretion under the Act in deciding whether to call for the appointment of a special counsel in any particular case. Nathan v. Smith, 737 F.2d 1069 (D.C. Cir. 1984). Judge Bork's concurring opinion stressed that this decision was grounded in constitutional concerns derived from the principle of separation of powers: "[W] may not lightly impute to Congress an intent to remove prosecutorial discretion from the Executive and place it in courts and private parties. Before the courts decide the constitutionality of such a transfer of the law enforcement power, it must be very clear that Congress has attempted it." Id. at 1079. Because Judge Bork's opinion focused on threshold jurisdictional questions, it made no judgment on the ultimate constitutionality of the statutory scheme, even as so interpreted. Id. at 1082.

156. 105 S. Ct. 1649 (1985).

157. Id. at 1656. 
suitability for judicial review of agency decisions to refuse enforcement."158 "An agency," the Court continued, "generally cannot act against each technical violation of the statute it is charged with enforcing. The agency is generally far better equipped than the courts to deal with the many variables involved in the proper ordering of its priorities,"159

The policy discretion exercised by executive agencies in promulgating general standards or implementing regulations may seem far removed from the prosecutorial discretion exercised in particular cases. But the Supreme Court has emphasized a similar constitutional perspective in cases dealing with rulemaking. ${ }^{160}$ In its recent decision in Chevron U.S.A., Inc. v. Natural Resources Defense Council, ${ }^{161}$ for example, the Court overturned a lower court's invalidation of the Environmental Protection Agency's ("EPA") "bubble policy." This EPA rule allowed increases in certain pollution sources if compensated for by greater decreases in other pollution sources in the same area (or under the same metaphorical "bubble"). Because the Clean Air Act ${ }^{162}$ did not explicitly prohibit this approach, the Court reasoned, Congress had left the issue to the policy judgment of the executive, and the lower court had thus acted improperly in substituting its own view of the most appropriate interpretation of the statute. The Court's reasoning is one of the clearest acknowledgments of the political dimension in executive implementing discretion:

Courts must, in some cases, reconcile competing political interests, but not on the basis of the judges' personal policy preferences. In contrast, an agency to which Congress has delegated policymaking responsibilities may, within the limits of that delegation, properly rely upon the incumbent administration's views of wise policy to inform its judg-

\footnotetext{
158. Id. at 1656 .

159. Id.

160. At first glance, rulemaking might seem too remote from the core executive functions to receive the same deference as the discretion exercised by prosecutors. In fact, Congress has delegated certain rulemaking powers to the executive from the very outset of its history. The first Congress authorized President Washington to issue rules and regulations for the control of trade with the Indians. Act of July 22, 1790, ch. 33, § 1, 1 Stat. I37 (July 22, 1790) (extended Mar. 1, 1793, repealed May 19, 1796). Even as a conceptual matter, moreover, there is no easy way to distinguish between settled prosecution or enforcement policies on the one hand, and "rules" on the other. A statement of enforcement policy, indicating which sorts of violations an agency will pursue (and which sorts of violations it will not pursue) is not different, after all, from a "regulation." Congress can, of course, limit the discretion of executive agencies in rulemaking by requiring that rules be justified on the basis of evidence developed in formal hearings. But as the D.C. Circuit noted in 1981, unless Congress has been quite explicit about its expectations, courts must assume that Congress has not intended to "convert informal rulemaking into a rarified technocratic process, unaffected by political considerations or the presence of Presidential power." Sierra Club v. Costle, 657 F.2d 298, 408 (D.C. Cir. 1981). For a thoughtful exposition of the argument that, under the Constitution, the president can never be entirely excluded from some supervisory or directive role in administrative rulemaking, see Strauss, The Place of Agencies in Government: Separation of Pouvers and the Fourth Branch, 84 CoLUM. L. REv. 573 (1984).
}

161. 467 U.S. 837 (1984).

162. 42 U.S.C. $\$ \$ 7401-7626$ (1982 \& Supp. III 1985). 
ments. While agencies are not directly accountable to the people, the Chief Executive is, and it is entirely appropriate for this political branch of the Government to make such policy choices-resolving the competing interests which Congress itself either inadvertently did not resolve, or intentionally left to be resolved by the agency charged with the administration of the statute in light of everyday realities. ${ }^{163}$

It is true that Congress may limit executive rulemaking discretion with more explicit and detailed statutory directives and with procedural requirements for developing rules on the basis of evidence established in formal hearings. But the very existence of administrative rules is an acknowledgment that statutory standards do not and usually cannot clarify policy in sufficient detail. And, as with prosecutorial discretion in particular cases, administrative rulemaking can rarely be governed entirely by legal formulas and mechanical criteria. The two functions involve similar considerations about the sufficiency of the evidence to justify a particular approach, the availability of alternatives, the capacities and resources of agency enforcement operations, and so on. ${ }^{164}$

This analysis suggests a strong constitutional presumption against allowing courts to direct executive agencies to particular results in rulemaking, as in individual enforcement decisions. The Court has been inconsistent in its rulings on the degree to which courts should defer to an agency's interpretation of its statutory mandate, although it has generally urged some degree of deference. ${ }^{165}$ Even where the courts have substituted their own judgments regarding the construction of statutory standards, however, they have rarely directed executive agencies to particular rulemaking results. Rather, the courts have almost always remanded challenged rules back to the agency for revision "in the light of" the court's construction of the relevant statutory mandate. ${ }^{166}$ This practice acknowledges that a good deal of discretion

163. Chevron, U.S.A., Inc, 467 U.S. at 865-66.

164. Professor Rabin provides a valuable analysis of the range of factors influencing the prosecutorial discretion of U.S. Attorneys in criminal referrals from federal agencies. Rabin, Agency Criminal Referrals in the Federal System: An Empirical Study of Prosecutorial Discretion, 24 Stan. L. REv. I036 (1972). Many of the same factors are applicable to administrative enforcement decisions and somewhat similar considerations can be applied to the discretion involved in rulemaking: "[M]any agencies, like the FTC, have the power to initiate cases as well as to decide them, and these agencies can exercise virtually the same degree of planning in the commencement of adjudicatory proceedings as they can in rulemaking." Shapiro, The Choice of Rulemaking or Adjudication in the Development of Administrative Policy, 78 HARv. L. REv. 921, 932 (1965).

165. The Court's inconsistency is emphasized in K.C. Davrs, 1982 SUPPLEMENT to ADministrative LAW TrEatise 580-85 (1982). Professor Davis discusses the divergence in approach between cases like INS v. Jong Ha Wang, 450 U.S. 139 (1981) (per curiam), in which the court held that the agency possessed "the authority to construe [the statutory ianguage] narrowly should they deem it wise to do so," id. at 145, and cases like Northeast Marine Terminal Co. v. Caputo, 432 U.S. 249 (1977) (9-0 decision), in which the Court construed the statutory language without regard for the agency's interpretation.

166. In the early period of administrative law, ... courts had not developed techniques to review the exercise of discretion on the part of administrators ... without usurping it. ... The absence of such techniques buttressed traditional separation-ofpowers concerns about judicial review of agency inaction. But the modern period 
must inevitably remain with implementing agencies, even in rulemaking. ${ }^{167}$

How much of this discretion may be bargained away in consent decrees without violating constitutional principles? The distinction between particular commitments and general policies is quite relevant to the answer. The pardon power, the classic example of executive discretion in enforcement, suggests a method for analyzing the distinction. Once granted by the president, a particular pardon may not be revoked by a subsequent president, or by Congress. ${ }^{168}$ The pardon is, in effect, an unbreakable contract with the recipient, protecting the pardoned individual against any future punishment for the particular offenses covered by the pardon. But a pardon can only cover specified, past offenses. A guarantee against punishment for unspecified future offenses would not be a pardon but the exercise of a dispensing power, a power unknown to the United States Constitution. ${ }^{169}$ Even the legislature may not bind its successors against penalizing specified behavior in the future, ${ }^{170}$ nor may the executive assume this power over future executives with open-ended guarantees of immunity. ${ }^{171}$ Administrative rulemaking, although it may narrow the prospective reach of a broad statutory prohibition, does not give one executive power over successors if the responsible executive agency remains free to change the rule and subsequently re-enlarge the scope of the prohibitions (with prospective effect).

The typical government consent decree does involve a binding promise not to prosecute, but it is no more problematic than a presidential pardon because it applies only to a discrete past offense. ${ }^{172}$

\footnotetext{
has seen the rise of a number of strategies by which courts might review the exercise of discretion without usurping the executive function. Courts may require explanations for decisions, and in reviewing those explanations, they may be quite deferential.

Sunstein, Reviewing Agency Inaction After Heckler v, Chaney, 52 U. Chr. L. Rev. 653, 671 (1985) (citation omitted).

167. For elaboration of the various understandings of agency discretion, see Koch, Judicial Reviezw of Administrative Discrelion, 54 GEo. WASH, L. REv, 469 (1986),

168. Although pardons may be granted conditionally, an absolute pardon may not be revoked, refused, or subsequently modified. See Schick v. Reed, 419 U.S. 256, 266 (1974); Ex Parte Grossman, 267 U.S. 87, 120 (1925); Ex Parte Wells, 59 U.S. (18 How.) 307, 315 (1855).

169. " $[\mathrm{A}]$ dispensing power ... has no countenance for its support, in any part of the constitution." Kendall v. United States ex rel. Stokes, 37 U.S. (12 Pet.) 524, 611 (1838). The claim of King James II to a dispensing prerogative-a power to authorize named individuals to act in violation of otherwise valid laws-was one of the royal abuses that provoked the Glorious Revolution of 1688. See F.W. Martland, The Constrtuttonal. History of England 302-06 (1913).

170. See Stone v. Mississippi, 101 U.S. 814 (1879) (statutory proscription of lotteries overrides a charter to a lottery company granted by state legislature in the preceding year).

171. See notes 58-66 supra and accompanying text.

172. Antitrust decrees sometimes present particularly awkward challenges to this rule because of the difficulty in determining when a business activity allegedly prohibited by a decree is "the same" offense. For further discussion of antitrust consent decrees, see Note, The Scope of Judicial Review of Consent Decrees Under the Antitnust Procedures and Penalties Act of 1974, 82 Mitch. L. REV. 153 (1983).
} 
Consent decrees that promise not to prosecute future offenses- even after the relevant rules are changed-must be regarded as nonbinding. ${ }^{173}$ So too must agreements that commit an agency to undertake particular types of levels of enforcement effort into the indefinite future. Such agreements not only foreclose reconsideration of broad public policy issues by subsequent administrations, but also constrain the reallocation of enforcement resources in response to altered circumstances and different appropriation levels. If courts could enforce broad agency commitments of this kind, then congressional control of agency funding would be undermined, as much as if the commitments involved direct financial outlays to private parties rather than internal agency resources. Similar reasoning applies to rulemaking. If courts could freeze particular rules or standards in place, they would prevent agencies from adapting to new funding levels, new circumstances, or new policy perspectives, contrary to the intent of Congress when it delegated rulemaking discretion to executive agencies.

\section{Interim Conclusions}

The Chadha decision emphasized that presidents may not bargain away their legislative prerogatives to Congress. We argue that executive officials have no greater authority to strike such bargains with private parties. We have also argued above that the executive branch must retain discretion in relation to broad spending and enforcement priorities in order to keep faith with legislative intentions. As available resources and external circumstances vary, administrators must be able to readjust their own operating policies and priorities, even if their activities are regarded as entirely subordinate to congressional expectations. Yet Supreme Court decisions on the presidential appointment and removal powers imply that even this implementing discretion, subordinate as it is to legislative control, is not simply a matter of adhering to congressional expectations.

For example, in Buckley $v$. Valeo, the Court noted that the president, rather than Congress or the courts, is charged by the Constitution to " "take Care that the Laws be faithfully executed." 174 And as the Court noted long ago in Myers $v$. United States, respect for this constitutional commitment helps to "secure that unitary and uniform execution of the laws which Article II of the Constitution evidently contemplated in vesting general executive power in the President alone."175 If the implementation of individual laws is guided at least in part by the claims of "uniformity" - of what is needed to harmonize with other administration policies-then actual patterns of enforcement or imple-

173. See notes $81,129-140$ supra and accompanying texts.

174. 424 U.S. 1, 138 (1976) (quoting U.S. ConsT. art. II, § 3).

175. 272 U.S. 52,135 (1926). 
mentation may often depart from the expectation of the Congress that enacted a particular law.

Arguably, Congress intends executive agencies to take varying circumstances and the claims of competing commitments into account in implementing particular legislative standards or directives. One can even argue that Congress forces this sort of continuous readjustment by altering funding levels and by adding new laws or programs that alter the overall policy context. But Supreme Court rulings on separation of powers suggest a still broader point: The Constitution requires Congress to leave implementing discretion to the executive, at least where congressional enactments allow for some exercise of judgment and discretion in implementation policy (as do virtually all measures). If the separation of powers means anything, it means that courts cannot entirely preempt the judgment and discretion of executive officials. That is, even if it wanted to do so, Congress could not simply convert the executive into an arm of the judiciary or grant plenary supervisory powers over administrative activity to the courts. This conclusion, grounded in part on the separation of powers, draws added force from the consideration that, in practice, delegations of power to the judiciary will usually involve delegations of governmental authority to the private parties bringing the cases to judicial notice and relying on an ultimate judicial sanction to negotiate settlements and remedies that affect broad government policies. And delegation of governmental power to private parties is delegation in its "most obnoxious form."176

It may be very difficult, amidst the complexities of contemporary administrative law, to find clear constitutional dividing lines that are unfailingly respected by the courts. But the existence of some lines, in principle, cannot be denied without denying that the Constitution imposes a definite division of authority between executive and judicial power. Courts implicitly acknowledge this constitutional division. First, courts have asserted that article III imposes definite "core requirements" for standing that even Congress may not waive or reduce. The Supreme Court has expressly rejected the notion that any executive decision or policy can be brought under judicial scrutiny by any complainant, notwithstanding its willingness to accomodate a considerable relaxation of standing barriers in recent decades. ${ }^{177}$ Second,

176. Carter v. Carter Coal Co., 298 U.S. 238, 311 (1936).

177. The case law on standing to sue in federal court is predominately a product of the contemporary judicial concern that legal protection be assured for interests beyond the traditional property claims protected at common law. As Joseph Vining poînted out, even the term "standing" was rarely used before World War II. J. Vining, LEGAL, IDENTITY, THE CoMING OF AGE OF PUBLIC LAW 55, 56 (1978). Before that time, the question at issue in standing, that is, who is authorized to bring a legal challenge before a court, was answered solely by the definition of particular causes of action: Someone claiming to have sustained injury to a legally protected right could bring a lawsuit. Then the lawsuit focused only on the question of whether the challenger's personal rights had or had not been violated. Under this traditional approach, government inaction in the courts was rarely challenged successfully. Further, private parties were rarely accountable at common law for inaction, except where the challenging 
party could appeal to some specific contractual duty owed specifically to him or her. Judicial review of administrative decisions, therefore, was largely confined to the protection of private property from government excess. Id. at $35-37$.

By contrast, the recent expansion of judicial review suggests that administrative inaction may also impose injury and that such injuries should be grounds for judicial intervention. The new approach was crystallized in the Supreme Court's 1970 decision in Association of Data Processing Service Organizations v. Camp, 397 U.S. 150, which interpreted the Administrative Procedure Act as conferring standing on any person "aggrieved" by an administrative decision, regardless of whether the administrative decision was made under a statute specifcally extending judicial review to all persons "aggrieved." Under the Data Processing test, a would-be challenger need only show that he or she had sustained "injury in fact, economic or otherwise" to contest an administrative decision in the courts. Id. at 152. The plaintiff need not prove that the challenged administrative action had violated some specially protected personal right of his own, but merely that the challenged action was contrary to statutory requirements or an "abuse of discretion."

The separation of standing requirements from the merits of a claim makes judicial review much more readily available because a challenger can more easily demonstrate injury in fact (that is, deprivation of advantages that might have been gained from a different administrative decision), than wrongful invasion or neglect of a distinct legal interest or right. In the $1970 \mathrm{~s}$, commentators like Vining accordingly expected that the law of standing would diverge more and more fully from private law notions of individualized rights and duties and would encourage the development of an entirely separate public law jurisprudence. The latter was expected to focus not on the correction of discrete wrongs to particular individuals, but on the enforcement of more extended "public values" in administrative law, with challengers of administrative decisions recognized as representatives of the public interest in these more extended values. J. VINING, supra, at 106-12, 179-81.

In fact, however, the Supreme Court has generally tightened standing requirements since the mid-1970s. First, the Court emphasized in several cases that the "core standing requirement" of "injury in fact" can only be satisfied by the showing of a "concrete injury" which is not simply that of a harm or disadvantage "undifferentiated from that of other citizens." Schlesinger v. Reservists, 418 U.S. 208, 217 (1974). More importantly, the Court gave teeth to this requirement by emphasizing that a would-be plaintiff must not only have shown a "concrete injury" to secure standing, but must have "shown an injury to himself that is likely to be redressed by a favorable decision." Simon v. Eastern Ky. Welfare Rights Org., 426 U.S. 26, 38 (1976) (emphasis added). While these limitations are not always easy to apply, their evident purpose is to ensure that judicial review comports with its traditional emphasis on the relief of individualized harms. Under these limitations, the more generalized is a complaint about administrative policy, the more questionable is the standing of a particular challenger because demonstration of a particular harm is more difficult with increasing generality. The Court's recent decision in Allen v. Wright, 468 U.S. 737 (1984), illustrates the force of these limitations. In Allen, the Court denied standing to black parents seeking to challenge the adequacy of Internal Revenue Service ("IRS") enforcement of non-discrimination requirements for taxexempt private schools, on the grounds that even if the IRS pursued a different enforcement strategy, there was no assurance that the particular schools near the would-be challengers would move toward greater integration rather than simply forfeit their tax exemptions.

The Court has not quite returned to Justice Stewart's suggestion that standing to challenge government inaction should be available only when the plaintiff seeks to enforce an affirmative government duty that "relates to a very particularized and explicit performance by the asserted obligor, such as the payment of money or the rendition of specific items of information." United States v. Richardson, 418 U.S. 166, 203 (1974) (Stewart, J., concurring). Indeed, recently the Court has avoided addressing standing problems directly so that it could reach the merits of particular cases. See, e.g., Hobby v. United States, 468 U.S. 339 (1984); Heckler v. Mathews, 465 U.S. 728 (1984). See generally Nichol, Rethinking Standing, 72 CaLIF. L. REv. 68 (1984) (noting inconsistent judicial approaches to standing); Miller \& Devins, Injuries and Remedies (manuscript in progress).

However, the Court has attempted to deny standing to the mere critic of government policy who might seek to "employ a federal court as a forum in which to air his generalized grievances." Richardson, 418 U.S. at 203 (quoting Flast v. Cohen, 392 U.S. 83, 106 (1968)). Thus, in Heckler v. Chaney, the Court suggested that judicial review of agency inaction was 
in detail even in cases properly before them. Courts have clarified the bounds of executive discretion under existing law and demanded that agencies clarify the factual and legal bases of their own policies, ${ }^{178}$ But they have tried to avoid a direct or complete preemption of executive policy discretion within the bounds allowed by law. ${ }^{179}$

If there are fundamental constitutional difficulties with direct judicial preemption of executive discretion, as this pattern of reticence and restraint implies, these difficulties are no less fundamental when the executive seeks to preempt its own discretion-or that of its successors-in binding consent agreements. The purpose of the constitutional division between executive and judicial power is to provide the executive with more discretion, more flexibility, and more room for political responsiveness than the judiciary. Unlike the judiciary, the executive is not bound by a fixed understanding of legislative intent-its own or that of its predecessors-because the resulting legalistic rigidity runs counter to the nature of executive power. ${ }^{180}$

Executive agencies must be able to make binding contracts and agreements in a wide range of circumstances, as in routine supply contracts, routine plea-bargaining agreements in law enforcement, and so on. The mere fact that an agreement curtails executive discretion cannot be an argument against judicial enforcement of the agreement.

generally inappropriate, and stated that: "[W]hen an agency refuses to act it generally does not exercise its coercive power over an individual's liberty or property rights, and thus does not infringe upon areas that courts often are called upon to protect." 105 S. Ct. 1649, 1656 (1985) (emphasis in original).

178. Note, for example, the modest scope of court orders in decisions such as Environmental Defense Fund v. Ruckelshaus, 439 F.2d 584 (D.C. Cir. 1971), requiring the EPA to explain and clarify its policies regarding suspension of dangerous pesticides: "Judicial review must operate to ensure that the administrative process itself will confine and control the exercise of discretion." Id. at 598.

179. Thus, for example, in National Research Defense Council, Inc. v. Gorsuch, which established the decree challenged in Citizens for a Better Environment, discussed in notes 342-347 infra and accompanying text, the Court concluded that "the primary touchstone for determining whether any given decree impermissibly infringes on an agency's discretion appears to be whether the decree is result or procedure oriented." 16 Env't Rep. (BNA) 2084, 2088 (D.D.C. 1982). Although we question the correctness of this conclusion, the conclusion is revealing of prevailing judicial cautions.

180. James Madison captured the complexity of the Framers' view of the executive in a speech to the Constitutional Convention, as he explained why life tenure was not appropriate for the chief executive or executive subordinates even though it could properly be accorded to the judges:

There was an analogy between the Executive \& Judiciary departments in several respects. [Both] ... executed the laws in certain cases [both] expounded and applied [the laws] for certain purposes.... The differences between them seemed to consist chiefly in two circumstances-I. the collective interest \& security were much more in the power belonging to the Executive than to the Judiciary department. 2 . in the administration of the former much greater latitude is left to opinion and discretion than in the administration of the latter.... [T] he $2 \mathrm{~d}$ consideration proves that it will be more difficult to establish a rule sufficiently precise for trying the Execut[ive]: than the Judges, [in an impeachment proceeding] \& forms an objection to the same tenure of office.

II The Records of the Federal Convention of 1787, at 34 (M. Farrand ed. 1911). 
When the executive purports to tie its hands in relation to fundamental policy prerogatives, however, its agreements cannot be enforceable any more than a legislature can be constrained by past contracts from exercising its broad, regulatory, or "sovereign" discretion.

We have suggested three applications of this principle in relation to executive consent agreements. First, no agreement can bind the president's veto or recommendation prerogatives in legislative matters, as these must extend as broadly as the legislative powers of Congress. Second, no agreement can bind the executive to spend funds not appropriated or authorized, or to refrain from altering "general and public" spending policies. Third, agreements on enforcement policy can only apply to action against past offenses and cannot irrevocably commit the executive to enforcement strategies, standards, or priorities in regard to future offenses.

In the next section, we will review several recent cases in which parties asked the courts to enforce consent decrees that we believe exceeded the above limitations. In the section that follows we will analyze the problems arising from the failure of these courts to articulate the constitutional limitations at issue in these cases.

\section{Recent Cases}

Five recent cases illustrate the range of circumstances in which, under the prevailing norms of ready access to the courts, executive agencies may make highly questionable consent agreements. Arising in the context of civil rights regulation, ${ }^{181}$ housing subsidy programs, ${ }^{182}$ domestic security policy, ${ }^{183}$ and environmental regulation, ${ }^{184}$ these cases have involved consent decree provisions affecting various aspects of the executive's discretionary authority. Included in these decrees, for example, were provisions requiring executive action on legislative proposals, ${ }^{185}$ budget proposals, ${ }^{186}$ adoption of new regulations, ${ }^{187}$ and

181. United States v. Board of Educ. of Chicago, 744 F.2d 1300 (7th Cir. 1984); Women's Equity Action League v. Bell, 743 F.2d 42 (D.C. Cir. 1984).

182. Ferrell v. Pierce, 743 F.2d 454 (7th Cir. 1984). banc).

183. Alliance to End Repression v. City of Chicago, 742 F.2d 1007 (7th Cir. 1984) (en

184. National Audubon Soc'y v. Watt, 678 F.2d 299 (D.C. Cir. 1982). A sixth case, Citizens for a Better Env't v. Gorsuch, 718 F,2d 1117 (D.C. Cir. 1983), involved a challenge to a consent decree in which the executive bargained away to environmental groups substantial discretionary authority. Unlike the other five cases discussed in this section, a subsequent administration did not challenge this negotiated limitation on its discretion. Instead, industry intervenors challenged the decree as an improper limitation on executive authority. Because the legal issues involved in Citizens for a Better Env't are very similar to those of the five other cases, we refer to Citizens for a Betler Env't in the foomotes in this section. See notes 342-347 infra and accompanying text for a fuller discussion of Citizens for a Better Env't.

185. Board of Educ. of Chicago, see notes 192-203 infra and accompanying text; Ferrell, see notes 240-247 infra and accompanying text; National Audubon Soc'y, see notes 232-238 infra and accompanying text.

186. Board of Educ. of Chicago, see notes 192-203 infra and accompanying text; Ferrell, see notes 240-247 infra and accompanying text. 
ongoing enforcement priorities. ${ }^{188}$ In all of these cases, efforts were subsequently made to enforce and to challenge these agreements in the context of policy changes under a new administration. ${ }^{189}$

For the most part, the appellate briefs submitted by government agencies in these cases called attention to some of the constitutional difficulties posed by these decrees. Not surprisingly, these constitutional arguments failed to impress the opposing parties. After all, the constitutional difficulties had already failed to dissuade federal district court judges from requiring that the consent decrees be enforced. ${ }^{190}$ Most of the appellate decisions rendered in these cases, while attempting to limit somewhat the policy reach of the decrees, further illustrate the reluctance of judges to come to grips with the constitutional issues involved. ${ }^{191}$ The various devices adopted by appellate courts to evade these constitutional problems seem quite unsatisfactory in a number of respects. In our view, therefore, these cases reinforce the conclusion that courts must articulate clear constitutional limitations on the entry and enforcement of government consent decrees.

\section{A. The Cases}

United States $v$. Board of Education of Chicago ${ }^{192}$ is the anomaly in this group of cases. It is the one case that was not brought by a public interest organization and the one case that did not involve a federal agency as the original defendant. Instead, the decree at issue arose from a long-standing desegregation suit against the Chicago school board in which the federal government was the original plaintiff. After years of highly publicized and rather controversial negotiations with the Chicago school board over the scope and adequacy of its desegregation efforts, the Carter Justice Department reached agreement with the school board on a remedial plan. ${ }^{193}$ The resulting consent decree was entered in the district court in September $1980^{194}$ and, although

187. Adams, see notes 213-231 infra and accompanying text; Ferrell, see notes 240-247 infra and accompanying text; Citizens for a Belter Env't, see notes 342-347 infra and accompanying text; Alliance to End Repression, see notes 206-211 infra and accompanying text.

188. Adams, see notes 213-231 infra and accompanying text; Cilizens for a Better Env'l, see notes 342-347 infra and accompanying text.

189. With the exception of that in Ferrell, these consent decrees were entered into during the Carter era; the Ferrell decree was a product of the Ford Administration. One suit to enforce a consent decree was filed during the Carter Administration, see National Wildlife Fed'n v. United States, 626 F.2d 917 (D.C. Cir. 1980).

190. See notes 223-279 infra and accompanying text.

191. See notes $280-312$ infra and accompanying text.

192. 554 F. Supp. 912 (N.D. Ill. 1983) (consent decree upheld), 567 F. Supp. 272 (N.D.

III, 1983) (injunction granted), aff'd in part and vacated and remanded in part, 717 F.2d 378 (7th Cir. 1983) (hereinafter Board of Educ, of Chicago I), on remland, 588 F. Supp. 132 (N.D. III. 1984), vacaled and remanded, 744 F.2d 1300 (7th Cir. 1984) (hereinafter Board of Educ. of Chicago II).

193. See generally Devins \& Stedman, New Federalism in Education: The Meaning of the Chicago School Desegregalion Cases, 59 Notre Dame L. Rev. 1243, 1258-63 (1984).

194. Consent Decree, United States v. Board of Educ. of Chicago, No. 80-C-5124 (N.D. IIl. Sept. 24, 1980) (hereinafter Consent Decree, Board of Educ. of Chicago). 
challenged as inadequate by the local NAACP and Urban League, was subsequently upheld by that court. ${ }^{195}$ Under paragraph 15.1 of the decree, both the federal government and the Chicago school board pledged "to make every good faith effort to find and provide every available form of financial resources [sic] adequate for the implementation of the desegregation plan."196 In May 1983, the Chicago school board claimed the federal government violated this provision. The district court agreed. It accordingly ordered the Education Department ("ED") to award as many discretionary grants to Chicago as necessary to fund its desegregation efforts and ordered the Reagan Administration as a whole to "take every affirmative step within its legal authority to seek and to 'find and provide' desegregation funding to the Board." 197 On appeal, the Seventh Circuit agreed that the Reagan Administration had violated paragraph 15.1 by failing to award adequate grants to Chicago from available ED funds. ${ }^{198}$ But the Seventh Circuit overturned the district court's remedial order, which had frozen spending by $\mathrm{ED}$ to preserve at least $\$ 14.6$ million for Chicago. 199

Over the following year, the Reagan Administration engaged in legislative and rulemaking activities that limited the amount of funding

195. Board of Educ. of Chicago, 554 F. Supp. at 913 n.2.

196. Consent Decree, Board of Educ. of Chicago, supra note 194, at 12. We find it curious that the government agreed to undertake substantial financial obligations in a lawsuit that it had initiated. We speculate that the Carter Administration may have made such a commitment in order to secure votes in Chicago for the 1980 presidential election. See Devins \& Stedman, supra note 193, at 1258-60. The possibility that such concerns might motivate negotiations in consent decrees exemplifies the risks inherent in far-reaching consent decrees, in terms both of unaccountability and constraints placed on subsequent executive policymaking.

197. Board of Educ. of Chicago, 567 F. Supp. at 286-88. The conflict between the school board and the United States arose, in part, because of recent changes in federal education assistance programs. At the time the consent decree was entered, Chicago was eligible for aid under the Emergency School Aid Act of 1972 (ESAA), Pub. L. No. 92-318, 86 Stat. 354 (1972) (codified at 20 U.S.C. $\$ \$ 1601-19$ (1982), repealed Pub. L. 95-561, \& 601(b)(2), 92 Stat. 2268 (1978)). Under this program, substantial federal assistance was available for activities directly related to the implementation of desegregation plans and to those districts most recently adopting desegregation plans. See Devins \& Stedman, supra note 193, at 1251-54. With the advent of the Reagan Administration, the ESAA ran afoul of the "new federalism" in education. See White House, America's New Beginning: A Program for Economic Recovery (1981). For elementary and secondary education, this "new federalism" called for consolidating forty-five federal programs (including the ESAA) in order to "shift control over education policy away from the Federal government and back to State and local authorities-where it constitutionally and historically belongs." Id. at 7-1. In response to this executive proposal, Congress enacted the Omnibus Budget Reconciliation Act of 1981, Pub. L. No. 97-35, 95 Stat. 357 (1981) (codified in scattered sections of 7, 12, 15, 20, 38, 42 U.S.C.). Among the programs repealed and consolidated was the ESAA. Congress gave the school districts-by way of state departments of education-block grants to be distributed among any of the number of activities that had previously been funded directly and individually by the federal government.

198. Board of Educ. of Chicago I, 717 F.2d at 382-85.

199. Id, at 382-85. Noting that the United States did not have an "adequate opportunity to challenge the remedies selected by the district court," id. at 385, the appellate court cautioned "[w] here another branch of government is found to be in violation of a court order, courts have shown a preference for allowing that branch to come into compliance voluntarily ...." Id. at 384 . 
available to the Chicago school board. ${ }^{200}$ At the same time, Congress enacted riders to ED appropriation bills which earmarked $\$ 20$ million for Chicago desegregation efforts, but also specified that no ED funds "shall be withheld from distribution to [other] grantees because of the provision of the order" issued by the district court. ${ }^{201}$ Though Chicago duly received its $\$ 20$ million, the district court found the Reagan Administration had acted in "bad faith" by supporting these legislative restrictions and by refusing to grant more than this amount. ${ }^{202}$ Accordingly, in August 1984, the district court ordered the "Executive Branch promptly to undertake some combination of ... lobbying activities to the extent necessary to assure financing adequate for implementation" of the Chicago desegregation plan ${ }^{203}$-and specified almost $\$ 104$ million as "adequate" for such financing. ${ }^{204}$ The government appealed this order to the Seventh Circuit Court of Appeals. ${ }^{205}$

The Seventh Circuit faced a somewhat different challenge to a government consent decree earlier in 1984, also growing out of an agreement signed by the outgoing Carter Administration in the fall of 1980 . In Alliance to End Repression v. City of Chicago, ${ }^{206}$ a coalition of civil rights and civil liberties organizations in Chicago (the "Alliance") sued the city and the federal government over surveillance activities. ${ }^{207}$ The coalition members charged that the government violated their first amendment rights by conducting this surveillance, which they claimed was in response to their public statements. ${ }^{208}$ As a result, paragraph 3.4(a) of the settlement agreement with the federal government promised that " $[t]$ he F.B.I. shall not conduct an investigation solely on the basis of activities protected by the First Amendment ...."209 In March of 1983, however, the Justice Department released new FBI investigative guidelines (for the entire country) noting that in "its efforts to anticipate or prevent crime, the FBI must at times initiate investigations in advance of criminal conduct" and that such investigations "may be warranted" when "statements advocate criminal activity ... unless it is apparent, from the circumstances or the context in which the statements are made, that there is no prospect of harm." 210 The plaintiffs in Alliance to End Repression pro-

200. Board of Educ. of Chicago II, 744 F.2d 1300, 1307-08 \& n.10 (7th Cir. 1984), cert. denied, 471 U.S. 1116 (1985).

201. Pub. L. No. 98-139, \$ 209, 97 Stat. 871,895 (1983).

202. Board of Educ. of Chicago, 588 F. Supp. 232, 238-39 (N.D. Ill. 1984).

203. Id. at 242 .

204. Id at 241 .

205. Board of Educ. of Chicago II, 744 F,2d at 1304.

206. 742 F.2d 1007, 1010 (7th Cir. 1984) (en banc).

207. Id. at 1009 .

208. Plaintiff's' allegations, as summarized by the court, were that the affected organizations "posed no actual or potential threat to domestic security, that the motivation for the investigation was the FBI's dislike of their political views, and that the goal and consequence of the investigation were to harass and intimidate the plaintiffs." Id.

209. Alliance to End Repression v. City of Chicago, 91 F.R.D. 182, 205 (N.D. Ill. 1981).

210. Alliance to End Repression, 742 F.2d at 1010 (quoting The Attorney General's Guidelines on General Crimes, Racketeering Enterprise and Domestic Security/Terrorism Investi- 
tested that this language violated the consent decree and persuaded the district court to issue an injunction against applying this portion of the new guidelines within Chicago. ${ }^{211}$ The Reagan Administration appealed. ${ }^{212}$

Adams v. Bell ${ }^{213}$, a District of Columbia Circuit case, also involved a consent decree signed by the Carter Administration which, according to the plaintiffs, the Reagan Administration had failed to honor.214 The case began with a 1970 suit, Adams $v$. Richardson, on behalf of black students and parents throughout the South (although it was not formally certified as a class action). The original suit complained of enforcement failures by the Office for Civil Rights ("OCR") then part of the Department of Health, Education and Welfare (and transferred after 1979 to the new Education Department). ${ }^{215}$ OCR enforces Title VI of the 1964 Civil Rights Act, which prohibits racial discrimination in any "program or activity receiving federal financial assistance," and also enforces parallel statutes prohibiting sex discrimination (Title IX) and discrimination against the handicapped (section 504).216 The original Adams suit protested OCR's failure to impose sanctions on several hundred named school districts in the South that the agency itself had found to be inadequately desegregated, and with which it had been negotiating for many months to secure remedial plans. The district court held these actions to be impermissible delays constituting an abuse of discretion. ${ }^{217}$ Accordingly, the court set a series of precise deadlines by which it required the agency to commence formal enforcement proceedings (unless the school districts had, in the meantime, agreed to comply with the agency's standards), ${ }^{218}$ The ruling was affirmed (with slight modifications) by the District of Columbia Circuit in 1973.219

The original plaintiffs returned to the district court in 1975 with a new list of delinquent school districts. ${ }^{220}$ They claimed that OCR delayed too long before proceeding to formal enforcement in these dis-

gations (March 7, 1983)) (emphasis provided by court in Alliance to End Repression). Plaintiffs alleged that these new guidelines contravened first amendment speech protections specified in the consent decree, claiming that speech can only be limited by a showing of immediate and substantial danger. Alliance to End Repression, 742 F.2d at 1011 (citing Brandenberg v. Ohio, 395 U.S. 444 (1969)(per curiam)),

211. Alliance to End Repression v. City of Chicago, 561 F. Supp. 575, 582-83 (N.D. Ill. 1983), modified, 733 F.2d 1187 (7th Cir.), reversed, 742 F.2d 1007 (7th Cir. 1984) (en banc).

212. Alliance to End Repression, 742 F.2d at 1010.

213. 743 F.2d 42 (D.C. Cir. 1984).

214. Id. at 43 .

215. Adams v. Richardson, 356 F. Supp. 92 (D.D.C,), modified, 480 F.2d 1159 (D.C. Cir. 1973) (en banc). Plaintiffs filed the original Complaint for Declaralory and Other Relief with the federal district court in the District of Columbia on October 19, 1970.

216. Title VI of Civil Rights Act of 1964 , codified at 42 U.S.C. $\$ 2000$ d (1982); Ticle IX of the Education Amendment of 1972, codified at 20 U.S.C. \$ 1681 et. seq. (1976); Section 504 of the Rehabilitation Act of 1973, codified at 29 U.S.C. $\$ 794$ (Supp. 1980).

217. Adams, 356 F. Supp. at $94-98$.

218. Id.

219. Adams v. Richardson, 480 F.2d 1159, 1164 (D.C. Cir. 1973) (en banc).

220. Adams v. Weinberger, 391 F. Supp. 269, 271 (D.D.C. 1975). 
tricts. This time the district court not only set deadlines for enforcement actions against the named school districts but also set general deadlines for investigation, mediation, and formal enforcement against any other school district (in seventeen specified southern states) about which OCR might receive complaints of racial discrimination. ${ }^{221}$ Efforts to satisfy this order occupied such a disproportionate share of OCR resources that the agency was soon charged with enforcement deficiencies in a range of other areas. ${ }^{222}$ In separate suits, parents of black school children challenged Title VI enforcement delays in northern and western states, ${ }^{223}$ parents of Hispanic school children challenged delays in enforcing bilingual education requirements under Title VI, ${ }^{224}$ groups concerned with sex discrimination challenged delays in enforcing Title IX, ${ }^{225}$ and groups concerned with the needs of disabled persons challenged delays in the enforcement of Section 504 of the Rehabilitation Act of 1974.226 The Carter Administration was rebuffed in its efforts to join all of these suits with Adams, ${ }^{227}$ but collective negotiations with all the various plaintiff groups led to a comprehensive settlement, endorsed by the Adams court at the end of 1977.228 Under the agreement, OCR promised to investigate all discrimination complaints under the three statutes within specified time frames and also to undertake specified numbers of agency-initiated compliance reviews on specified issues within specified processing deadlines. ${ }^{229}$

OCR has never succeeded in meeting the agreed "timeframes" for all of its cases. With significant expansion in staff and resources, it had improved its record considerably by the summer of 1979 , but thereafter its performance deteriorated notably. ${ }^{230}$ Various plaintiff groups returned to court in 1981 to protest these violations of the consent de-

221. Id. at 273 .

222. See, e.g., Motion for Intervention, Adams v. Mathews, No. $3095-70$, slip op. (D.D.C. June 14, 1976) (claiming that the OCR refused to act on complaints of discrimination against non-English-speaking minorities on the grounds that compliance with Adams orders preempted all available resources) (on file with the Stanford Law Review).

223. Brown v. Weinberger, 417 F. Supp. 1215 (D.D.C, 1976).

224. Adams v. Mathews, No. 3095-70, slip. op. (D.D.C. June 14, 1976).

225. Women's Equity Action League v. Matthew, (No. 74-1720) (D.D.C. 1974).

226. Application for Leave to Intervene as Plaintiffs, National Federation of the Blind, Douglas S. Usiak \& Joyce S. Stiff (June 28, 1977).

227. Order of Judge Pratt, Oct. 24, 1977 (on file with the Stanford Law Review).

228. Adams v. Califano, 430 F. Supp. 118 (D.D.C. 1977).

229. For example, the decree required that (1) within 105 days of the receipt of a complete complaint, OCR shall make a written determination as to whether a violation has occurred; (2) OCR must investigate all allegations of the complaint, interview the complainants and witnesses, and permit complainants an opportunity to rebut adverse evidence; (3) within 180 days of beginning a compliance review, OCR must conclude negotiations for corrective action if a violation has been found; and (4) at least 60 days prior to the beginning of each fiscal year, OCR must publish a proposed operating plan for public comment. Id.

230. Deposition of Cynthia Brown, former Deputy Director for Compliance and Enforcement of OCR, at 56-57, 83-84, Adams v. Bell, 743 F.2d 42 (D.C. Cir. 1984). Brown reported that OCR had met its "timeframes" under Adams in $64 \%$ of its cases in August 1979. However, this figure had dropped to $40 \%$ by September 1979 . Id. 
cree and in 1983 won a supplementary order from the district court reconfirming the essence of the original decree while accommodating some modifications to make it more enforceable. ${ }^{231}$ The Justice Department appealed.

The District of Columbia Circuit confronted another alleged violation of a consent decree in National Audubon Society $v$. Watt. ${ }^{232}$ In that case, both the Carter Administration, which had signed the original agreement, as well as the new Reagan Administration, tried to resist enforcement of the decree. The Audubon Society had filed suit in 1976, seeking to block the Interior Department from going ahead with a vast water project in North Dakota in alleged violation of the National Environmental Policy Act. ${ }^{233}$ A stipulation and order entered in 1977 required the Interior Department to refrain from further construction until it had completed two environmental impact studies on the project, submitted proposals to Congress, and secured actual legislation "reauthorizing, modifying or deauthorizing the project."234 The Department subsequently completed the studies, but submitted no legislative proposals on the matter to Congress.235 Congress did not explicitly reauthorize, deauthorize, or modify the project. But Congress did continue to appropriate funds for the project each year and when President Carter notified Congress of his decision not to expend the appropriation, the Senate voted to disapprove this deferral of funding for the water project. ${ }^{236}$ The Interior Department interpreted this vote as releasing it from the stipulation. ${ }^{237}$ But the National Audubon Society claimed that only an explicit reauthorization by Congress could allow the project to go forward and eventually obtained an injunction from the district court prohibiting the Department from continuing work on the project until Congress had acted more explicitly, as provided by the original stipulation. ${ }^{238}$ The injunction, handed down in May 1981, was appealed to the District of Columbia Circuit by the Reagan Administration. ${ }^{239}$

Another case of this kind, Ferrell $v$. Pierce, ${ }^{240}$ arose in the Seventh Circuit and involved a mortgage insurance program operated by the Department of Housing and Urban Development ("HUD"). In 1976, HUD settled a suit brought by low-income homeowners in the Chicago area and promised to take assignment of the mortgages of these home-

231. Order, Adams v. Bell, C.A. 3095-70 (Mar. 11, 1983) (on file with the Stanford Law Review).

232. 678 F.2d 299 (D.C. Cir. 1982).

233. Id. at 302.

234. Id. at 301 .

235. Id. at 303 .

236. Id. at 304 .

237. Id.

238. Id. at 304-05.

239. Id. at 305.

240. 743 F.2d 454 (7th Cir. 1984). 
owners, under certain conditions, to prevent foreclosures by the original mortgagees. ${ }^{241}$ When the plaintiffs subsequently charged HUD with failure to observe the terms of this agreement in 1979, the parties agreed to an amended stipulation. ${ }^{242}$ HUD promised that "it would operate the assignment program for five years in accordance with its newly-revised handbook"; that "it would not, during [this period] curtail the 'basic rights' of participating mortgagors"; that it would "give notice to plaintiffs' counsel prior to final action on any modification"; and, that after the expiration of the five year period, it would continue the assignment program or an "equivalent substitute." 243 In 1980, on HUD's recommendation, Congress enacted the Temporary Mortgage Assistance Program ("TMAP") as a means of coping with skyrocketing costs under the mortgage assignment program. ${ }^{244}$ Under TMAP, HUD would not take over mortgages when insured, low-income homeowners were threatened with foreclosure, but would simply assist them in meeting their monthly payments to the original mortgagees. ${ }^{245}$ When HUD sought further to amend the 1979 amended stipulation in Ferrell to specify that TMAP assistance would satisfy its requirements, the district court judge refused to allow the change. ${ }^{246}$ HUD's implementing regulations for TMAP, the district judge found, had tightened eligibility requirements and lowered the quality of mortgage assistance in various ways so that it was not really an "equivalent substitute."247 The Reagan Administration appealed this ruling to the Seventh Circuit. ${ }^{248}$

\section{B. The Arguments}

The government attacked these consent decrees on grounds as pedestrian as the precise meaning of the particular consent decree ${ }^{249}$ and

241. See id at 457.

242. See id.

243. Id. at 457-58.

244. Housing and Community Development Act of 1980, Pub. L. No. 96-399, § 341, 94

Stat. 1614 (1980) (amending 12 U.S.C. \$ 1715 (Supp 1987)).

245. See Ferrell, 743 F.2d at $458-460$.

246. Ferrell v. Pierce, 560 F. Supp. 1344, 1349 (N.D. Ill. 1983), aff'd 743 F.2d 454 (7th Cir. 1984).

247. Id. at 1359-72.

248. Ferrell, 743 F.2d at 455

249. In Board of Education of Chicago I, for example, the issue of government liability centered on a consent decree provision that "[e]ach party is obligated to make every good faith effort to find and provide every available form of financial resources adequate for the implementation of the desegregation plan." Consent Decree at 12, Board of Educ. of Chicago I, supre note 194. The Board argued that the government had "entered into a consent decree by which it agreed ..... [u]nder judicial supervision, to be mutually responsible with a school board for funding a desegregation plan." Brief for the Board of Education of Chicago at 1 , Board of Educ. of Chicago I, 717 F.2d 378 (7th Cir. 1983) (Nos. 83-2308, 83-2402, 83-2445) [hereinafter Brief for Board of Education, Board of Educ. of Chicago I]. The Board interpreted this obligation as a specific commitment to Chicago, not merely a general obligation that permitted Chicago to compete with other school districts for congressionally authorized education funds. The United States disagreed and claimed that the consent decree "does not require the Executive Branch .... to prefer Chicago over other school districts ... . in dispens- 
as lofty as the general constitutional authority of the judiciary under article III ${ }^{250}$ or of the executive under article II. ${ }^{251}$ In between these extremes, there were arguments about the meaning of statutory provisions underlying the decrees, ${ }^{252}$ the significance of related congres-

ing federal financial assistance and structuring federal assistance programs." Brief for the United States at 16, Board of Educ. of Chicago 1, 717 F.2d 378 (7th Cir. 1983) (Nos. 83-2308, 832402, 83-2445) [hereinafter Brief for United States, Board of Educ. of Chicago I]. The Board prevailed on this matter, thus forcing the Executive either to modify its position or to justify noncompliance on constitutional grounds. Board of Educ. of Chicago I, 717 F.2d at 382-83; see notes 281-292 infra.

Aliance to End Repression involved a provision stipulating that " $[\mathrm{t}]$ he FBI shall not conduct an investigation solely on the basis of activities protected by the first amendment." Alliance to End Repression, 91 F.R.D. 182, 205 (N.D. Ill. 1981) (citing Joint Motion and Stipulation at 19). The government read this provision narrowly, contending that it "bars the FBI from conducting an investigation, the sole purpose of which would be to suppress or harass the exercise of protested speech." Brief for Appellants at 19, Alliance to End Repression y. City of Chicago, 733 F.2d 1187 (7th Cir. 1984), rev'd 742 F.2d 1007 (7th Cir. 1984) (en banc) (Nos. 83-1853, 83-1854) [hereinafter Brief for Appellants, Alliance]. Plaintiffs, using first amendment Supreme Court decisions as a point of reference, argued that "the phrase "protected by the First Amendment' is a term of art with a well-defined meaning encompassing all advocacy that is not likely to and intended to lead to imminent criminal activity." Brief for American Civil Liberties Union at 8, Alliance to End Repression v. City of Chicago, 733 F.2d 1187 (7th Cir. 1984), rev'd 742 F.2d 1007 (7th Cir. 1984) (en banc) (Nos. 83-1853, 83-1854) [hereinafter Brief for ACLU, Alliance]; see notes 293-299 infra.

250. See notes 265-267 infra and accompanying text.

251. See notes 259-264 infra and accompanying text.

252. National Audubon Sociely concerned the authority of the Secretary of Interior under the National Environmental Policy Act ("NEPA"). Although neither side disputed that the Secretary could defer construction of a public works contract either to undertake environmental impact studies or to permit Congress an opportunity to further study the project, sharp disagreement existed as to whether the Secretary, under NEPA, could unconditionally delay construction of a previously approved project until Congress again addressed the issue. The government argued that "NEPA [only] gives the Secretary discretion to defer construction of an authorized project for a reasonable period of time so that Congress may consider alternatives to the project." Brief for Federal Appellants at 26, National Audubon Soc'y v. Watt, 678 F.2d 299 (D.C. Cir. 1982) (Nos. 81-I641, 81-1763) (emphasis added) [hereinafter Brief for Federal Appellants, National Audubon Soc'y]. Countering this argument, the National Audubon Society alleged that "[i]f the Secretary has the ability to defer project activity at all, he should certainly be able to continue that deferral until the objectives of NEPA [that underlie the agreement] have been attained, or until Congress has determined that he should proceed." Brief for National Audubon Society at 30, National Audubon Soc'y, Inc. v. Watt, 678 F.2d 299 (D.C. Cir. 1982) (Nos. 81-1641, 81-1763) [hereinafter Brief for National Audubon Society, Nat'l Audubon Soc'y].

Appellate briefs in Citizens for a Betler Env't also framed their arguments around a statutory question. They focused upon whether the challenged consent decree provisions created additional obligations for the EPA beyond those required by the Clean Water Act. Compare Brief for Appellants American Iron and Steel Institute at 28-31, Citizens for a Better Env't v. Gorsuch, 718 F.2d 1117 (D.C. Cir. 1983) (Nos. 82-1365-68, 1673-76, 1770-73) [hereinafter Brief for Industry Intervenors, Citizens], with Brief for Federal Appellees at 18-24, Citizens for a Better Env't v. Gorsuch, 718 F.2d 1117 (D.C. Cir. 1983) (Nos. 82-1365 etc.) [hereinafter Brief for Federal Appellees, Citizens].

Adams is one other case in which the government emphasized questions of statutory interpretation. In its effort to nullify the 1977 consent decree, the government argued that "neither the language of those provisions [on which the decree is based], their legislative histories, nor cases construing similar legislation support the pervasive regulation embodied in the district court's [enforcement of the consent decree]." Brief for Appellants at 37-38, Adams v. Bell, 743 F.2d 42 (D.C. Cir. 1984) (Nos. 83-1516, 83-1590) [hereinafter Brief for Appellants, Adams]. This issue was not explicitly addressed in the civil rights plaintiffs' brief, although much of that brief concerned the executive's failure to enforce those statutes. Brief 
sional actions, ${ }^{253}$ presumptions regarding the resolution of ambiguities in executive contracts, ${ }^{254}$ distinctions between stipulations of settlement and consent decrees, ${ }^{255}$ and the significance of related court decisions. ${ }^{256}$ Significant (and frequently novel) as these issues may be, our

For Appellees at 63-64, Adams v. Bell, 743 F.2d 42 (D.C. Cir. 1984) (Nos. 83-1516, 83-1590) [hereinafter Brief for Appellees, Adams].

253. Two cases that raised this issue are Board of Educalion of Chicago II and Citizens for a Better Environment. The significance of a 420 million dollar appropriations rider enacted in response to the district court's decision to freeze 420 million dollars of federal education funds was at issue in Board of Education of Chicago II. For a discussion of these measures, see Devins \& Stedman, supra note 193, at 1282-84. Referring to debates surrounding this appropriation, the United States argued that Congress intended its appropriated education funds to benefit school children throughout the nation. Brief for United States at 52-59, Board of Educ. of Chicago II, 744 F.2d 1300 (7th Cir. 1984) (No. 84-2405) [hereinafter Brief for United States, Board of Educ. of Chicago II]. The Board, while not disputing this claim, contended that "[n]othing in the plain language or legislative history of these provisions reflects any Congressional determination affecting the availability of funds to be provided to the Board." Brief for Board of Education of Chicago at 57, Board of Educ. of Chicago II, 744 F.2d 1300 (7th Cir. 1984) (No. 84-2405) [hereinafter Brief for Board of Education of Chicago, Board of Educ. of Chicago II]. For further discussion of the issue of whether courts should view appropriations riders as substantive legislation, see Devins, Appropriations Riders as Subslantive Legislation (manuscript in preparation).

Citizens for a Better Environment raises another interesting question pertaining to congressional review of consent decree settlements. In 1977, Congress amended the Clean Water $\mathrm{Act}$, in part because of the use of consent decree settlements to rectify the alleged delinquency of the EPA. See Environmental Defense Fund, Inc. v. Costle, 636 F.2d 1229, 1238-44 (D.C. Cir. 1980). The government contended that such congressional awareness effectively codified the consent decree. By contrast, industry appellants argued that Congress did not concern itself with those consent decree provisions limiting EPA discretionary authority. Compare Brief for Federal Appellees at 46, Citizens, supra note 252, with Brief for Industry-Intervenors at 47-49, Citizens, supra note 252. See also Grabow, Congressional Silence and the Search for Legzslative Intent: A Venture into Speculative Unrealities, 64 B.U.L. REv. 737 (1984).

254. For a general discussion of the executive's contractual obligations, see notes 58-79 sufra and accompanying text. At issue here is whether consent decrees should be interpreted so as not to infringe on the executive's article II policymaking responsibilities. The executive raised this argument in Board of Educ. of Chicago II, 744 F.2d 1300 (7th Cir. 1984). In that case, the United States tried to sway the Seventh Circuit to read the settlement agreement narrowly because

[t]o the extent that the district court read into the consent decree, by implication, any such constraints on the President's constitutional powers, its strained interpretation must give way to one more reasoned-one that does not seek to invade the exclusive province of the President-if the decree is to survive.

Brief for the United States at 35, Board of Educ. of Chicago II, supra note 253. In response to this argument, the school board contended that to entitle the government to "read out of consent decrees any provision that the government later finds burdensome .... would undermine respect for the rule of law, and deprive both citizens and the government of the benefits of settling litigation." Brief for Board of Education of Chicago at 39, Board of Educ. of Chicago II, supra note 253.

255. Stipulations of settlement function as stays on litigation, not as permanent settlements. See Gaba, Informal Rulemaking by Settlement Agreement, 73 GEO. L.J. 1241 (1985). In National Audubon Socy, the parties entered into a hybrid agreement. The National Audubon Society agreed to suspend litigation pending the introduction of legislation by the Secretary of Interior. See National Audubon Soc y, 678 F.2d. at 301. Viewing the arrangement as tentative, the United States claimed that "[i]t is time to declare the Stipulation dead so that Secretary Watt may have available to him the full range of discretion to which he is entitled .... and so that all parties may press forward to a conclusion of this litigation on the merits." Brief for Federal Appellants at 20-21, National Audubon Soc'y, supra note 252.

256. In Adams, the government sought modification of the decree because "[j]udicial decisions since $1977 \ldots$ establish that th[e] conception of how these statutes [which underlie 
focus is limited to questions involving the article II responsibilities of the executive and the authority of the courts under article III. Most of the briefs did address the constitutional issues. ${ }^{257}$ In their simplest form, the arguments pitted the sanctity of contracts against the article II responsibilities of the executive in our tripartite governmental scheme.

The United States argued that "it is within the exclusive authority of the President to propose, support, oppose, sign, or veto legislation, as he and only he deems necessary and expedient." 258 To the extent that

the consent decree] work is wrong and that the purpose of the consent decree is outdated." Brief for Appellants at 65 , Adams, supra note 252 . The plaintiffs asserted both that there had been no change in decisional law and that "even if the decisional precedent upon which an injunction is based is overruled, the injunction is not to be vacated." Brief for Appellees at 47, Adams, supra note 252 . Without addressing the question of whether there was a change in decisional law, it is worth noting that such a change in all likelihood constitutes sufficient justification for the modification of a consent decree.

257. Briefs in Alliance to End Repression did not directly raise the issue. Instead, these briefs focused on the analogous issue of whether, for purposes of consent decree interpretation, a presumption should exist that government would not contract away discretionary policymaking authority. Arguing that contracts should be construed in the public interest, the United States contended that "[ $[\mathrm{c}]$ here is unquestionably a significant public interest in the ability of the government to 'safeguard[] its own capacity to function... [in order] to preserve the security of its people. ..." Brief for Appellants at 43, Alliance, supra note 249 (quoting United States v. United States District Court, 407 U.S. 297, 312 (1972)). Also noting that limitations on domestic security investigations run "contrary to its constitutional obligation" to preserve, protect, and defend the Constitution, the United States claimed that the Alliance to End Repression consent decree "must be construed in light of the strong public policy consideration of that fundamental governmental obligation." Id. at 44. Appellee American Civil Liberties Union ("ACLU") argued that public policy considerations supported the agreement. Specifically, the ACLU noted the interest both in settlement and in preventing the sort of FBI misconduct that spurred on this litigation. Brief for ACLU at 26-29, Alliance, supra note 249.

The one case in which the government took a different approach is Citizens for a Belter Environment, where the United States, after unsuccessfully seeking District Court deletion of those provisions of the decree not expressly mandated by statute, claimed that the consent decree was a "classic settlement." Although not reversing itself on this issue, the United States asserted that it chose not to appeal this ruling because of "a wide array of factors including consideration of factors outside the confines of this litigation." Brief for Federal Appellees at 51, Citizens, supra note 252. In its appellate brief, however, the United States advanced arguments inconsistent with its earlier position. Most notably, the government claimed both that the decree did not impermissibly intrude into EPA affairs and that, "in many respects, the decree was an accommodation to EPA's discretion." Id. at 40 . In fact, the United States argued that " $[t]$ he government's ability to negotiate such settlements may often depend-as it did in this case - on its ability to be bound, through a consent decree, to take certain discretionary actions." Id. at 43.

This argument is blatantly inconsistent with the EPA's earlier position in this case-a position that EPA claims (in the same brief) to be correct. Also remarkable is the fact that EPA would make such an argument when environmental plaintiffs had threatened to bring contempt proceedings against EPA because of their alleged "dissatisfaction with the agency's strategy." Id. at 50. Moreover, EPA's position is inconsistent with the government's position in analogous cases. This inconsistency was highlighted in Industry-Intervenors brief in Citizens for a Better Environment. Brief for Industry-Intervenors at 49-51, 54-57, Citizens, supra note 252. Referring to the government's position in Nalional Audubon Soc'y, industry intervenors noted that "the Government stated flatly that the judicial order embodying the stipulation in question was no longer binding because "the judicial branch is without power to command the executive branch to exercise its discretionary powers in any particular manner.' "Id. at 50 (quoting Brief for Federal Appellants at 17, National Audubon Soc'y, supra note 252).

258. Brief for United States at 61, Board of Educ. of Chicago II, supra note 253. 
consent decrees regulate "the President's constitutional authority to recommend to Congress such measures as he believes proper," they interfere with "the political discourse that is vital to the day-to-day relationship between the Executive and Legislative Branches of government."259 In addition to the president's plenary authority in activities directly affecting legislative-executive interaction, government briefs invoked the president's constitutional duty to faithfully execute the laws and urged that this responsibility provides constitutional protection for the implementing discretion of administrative agencies. ${ }^{260}$ The government insisted that enforcement of consent decree settlements cannot be tolerated when such enforcement "effectively freezes [a] regulatory scheme into place, denying the agencies the flexibility to shift approaches due to changing circumstances or even to profit from their experience."261

Claiming that one administration cannot bind a successor administration in the exercise of its discretionary power, the United States argued that "[w]here the laws leave room for the exercise of discretion, the executive branch must be free to implement those laws in a manner that is consistent with its own policies." 262 In this spirit, the United States contended that dissatisfaction with discretionary public policy decisions ${ }^{263}$ should be addressed at the polls, not the courts:

[T] he Constitution provides for Presidential elections every four years, and for the appointment of agency and department heads by the President. New Directors and Secretaries are entitled to make judgments about how to operate their agencies .... These fundamental democratic precepts do not permit officials to mortgage their responsibilities by entering into consent orders tying their successor's (sic) hands in the overall management of the agency. ${ }^{264}$

259. Id. at 33-34.

260. Brief for Appellants at 48-49, Adams, sufra note 252 (quoting Vermont Yankee Nuclear Power Corp. v. NRPC, 435 U.S. 519, 525 (1978) (quoting FCC v. Schreiber, 38I U.S. 279,290 (1965)). In its Adams brief, the United States sought to support this claim on two grounds, namely: (1) " ' $[$ A]gencies should be free to fashion their own rules of procedure and to pursue methods of inquiry capable of permitting them to discharge their multitudinous duties' " and (2) "the day-to-day management of that administrative process-including determining how long it takes to investigate a given case and to prepare reasoned findings, when negotiations are no longer fruitful, and how much time is necessary to take a case to enforcement-is an executive function." Id.

261. Id. at 53. As stated by the government in Adams: "This proceeding no longer embodies a controversy between particular injured plaintiffs and the government; it has become an endless judicial receivership of the civil rights enforcement functions of two large agencies." Id. at 58 .

262. Brief for Federal Apellants at 18, National Audubon Soc y'y, supra note 252.

263. On matters mandated either by statute or the Constitution, the government recognizes that a court may order, or an agency may agree to, a change in executive practices. See, e.g., Brief for Appellants at 64 n.62, Adams, supra note 252.

264. Id. at 63-64. As recognized by the Supreme Court in Chevron U.S.A., Inc. v. Natural Resources Defense Council, 467 U.S. 837, 865-66 (1984), a change in administration may support executive branch reassessment of predecessor policies. See also Motor Vehicle Mfrs. Ass'n v. State Farm Mut, Auto. Insur., 463 U.S. 29, 59 (1983) (Rehnquist, J., concurring in part and dissenting in part) ("As long as the agency remains within the bounds established by 
Related to these concerns, the United States argued that article III courts are without authority either to enter or enforce executive consent decree settlements that impinge on protected policymaking discretion. Citing System Federation No. 91, Railway Employees' Department v. Wright, ${ }^{265}$ the government argued that a court could not enter consent decree settlements broader than that which a court could order in adjudicating the case if it had gone to trial. ${ }^{266}$ The brief for the United States in the 1984 Chicago Board of Education case asserted: "The President's decisions to support or oppose legislation, his provision of assistance to Members of Congress, and his communications with Congress are not subject to judicial inquiry and no contract, consent decree or court order could, consistent with the Constitution, subject such decisions to judicial inquiry." 267

The plaintiffs in these cases saw the matter differently, of course. In addition to challenging the government on both the scope of executive branch discretion and the authority of article III courts, plaintiffs emphasized the sanctity of contracts, the public interest in the efficient settlement of lawsuits, and the integrity of the judicial process.

Plaintiffs advanced numerous arguments to rebut the government's claims about the separation of powers. Some briefs boldly dismissed such claims altogether: "Article II, Section 3 merely establishes the Executive's ability to recommend matters to Congress; it does not address the accountability of the Executive Branch for its failure to meet an obligation to do so," 268 On another level, plaintiffs, by defining sep-

Congress, it is entitled to assess administrative records and evaluate priorities in light of the philosophy of the administration.") (footnote omitted).

265. 364 U.S. 642 (1961); see notes 24-27 supra and accompanying text.

266. An analogous argument was made in Adams: Courts should be circumspect in their dealings with other branches of government (even in the approval of executive-crafted consent decrees) because of concern about the " 'proper-and properly limited role of the courts in a democratic society." "Brief for Appellants at 63, Adams, supra note 252 (quoting Warth v. Seldin, 422 U.S. 490,498 (1975)).

267. Brief for the United States at 62, Board of Educ. of Chicago II, supra note 253 (citations omitted). Pointing to the fundamental equitable requirement of a fit between remedy and violation, the United States further argued that if it had agreed in a consent decree "to restrict the President unconstitutionally in his dealings with Congress or to commit unlimited financial assistance in contravention of its legal authority," a court would be obligated to invalidate the decree. $I d$, at 65 (citation omitted).

The most extensive presentation of the judicial authority issue was contained in IndustryIntervenors' brief in Citizens for a Better Environment. In instances where Congress has granted the executive discretionary authority, " 'a court may not compel an administrative agency to pursue a particular course of action when another is open to it.' " Brief for Industry-Intervenors at 22, Citizens, supra note 252 (quoting Public Serv. Comm'n. v. Federal Power Comm'n., 543 F.2d 757, 833 n.42 (D.C. Cir, 1974)). Although the executive may play a substantial role in drafting a settlement agreement, the brief notes that the entry and modification of a consent decree is a judicial act. Id. at 21 . To support their claim, the intervenors cited a number of court cases concerned with the judiciary's limited role in the operation of government. See id. at 21-27, 32-34, 51-54. 253.

268. Brief for Board of Education of Chicago at 74, Board of Educ. of Chicago II, supra note 
aration of powers as interbranch friction, ${ }^{269}$ contended that the constitutionally mandated balance among the three branches is preserved wherever the executive voluntarily enters into a consent decree. ${ }^{270}$ Plaintiffs thus viewed the government's separation of powers argument as an "effort to create a world where there are no restrictions for administrators. ... The truth, of course, is that new administrations frequently and properly take office with their options limited by the actions of their predecessors, by acts of Congress, and by judicial decrees."271

The plaintiffs' arguments about the authority of federal courts followed from their view of the separation of powers. Viewing the executive's initial consent as sufficient to validate a decree, the plaintiffs depicted the article III authority issue as concerning only the general equitable powers of federal courts. ${ }^{272}$ Viewing this power quite broadly in the context of private party efforts to force public officials to comply with their legal duties, plaintiffs argued that where "a court is exercising its equitable powers in a public interest context, there are no grounds for a niggling view of the reach of the court's power to grant relief."273

Plaintiffs thus argued that the executive, like any private party, is bound by its contracts. ${ }^{274}$ As stated by the civil rights groups in Adams, "[i]t shocks the conscience to suggest that the Government ... should be less bound than other litigants by the terms of duly promulgated consent decrees issued to vindicate federal statutory and constitutional

269. See Logan, Standing to Sue: A Proposed Separation of Powers Analysis, 1984 WIS. L. REv. 37. But see J. Agresto, The Supreme Court and Construtional Democracy 10 (1984) (separation of powers ensures each branch the right to develop its own constitutional principles).

270. There is no disruption of the balance between coordinate branches because the Executive Branch properly exercised a constitutionally assigned power when it chose to enter the Consent Decree. Having once made this decision, it can hardly be said that judicial enforcement of its obligations is an uninvited intrusion into the exercise of its powers.

Brief for Board of Education of Chicago at 70, Board. of Educ. of Chicago II, supra note 253; see also Brief for Appellees at 54-55, Adams, supra note 252. The United States, contrary to its position in all other cases, argued in Cilizens for a Belter Environment that " $[t]$ he fact that EPA was a prime formulator of the consent decree is highly relevant to the issue of whether the decree constitutes a permissible constraint on the agency's discretion." Brief for Federal Appellees at 39, Citizens, supra note 252.

271. Brief for Appellees at 59, Adams, supra note 252.

272. "The district court did not compel the Secretary to elevate environmental concerns over all others; it merely ordered him to adhere to a contract in which he agreed to exercise his discretion in a certain and permissible manner." Brief for National Audubon Society at 28 n.4, Nat'l Audubon Soc'y, supra note 252; see also id. at 18-27,47-48; Brief for Board of Education at 75-76, Board of Educ. of Chicago II, supra note 253.

273. Brief for Natural Resources Defense Council at 20-21, Citizens for a Better Env't v. Gorsuch, 718 F.2d 1117 (D.C. Cir. 1983) (Nos. 82-1365, etc.) [hereinafter Brief for NRDC, Citizens]. In Citizens for a Better Environment, consumer group appellees argued that three principles support broad equity powers in this type of case: (1) equity should rest in the sound discretion of the court; (2) where the executive does not comply with his legal duties, specific decrees should be favored; and (3) the scope of equitable remedies may be greater when public interest concerns are involved. Id. at 19-20.

274. Id. 
[Vol. 40:203

requirements,"275 Taking this argument one step further, the school board in Board of Education of Chicago II, noting that a consent decree is a final judicial order, contended that the " "duty of compliance is particularly important when Government officers are involved, for " $[t]$ he greater the power that defies the law the less tolerant can this Court be of defiance." "276

The final argument advanced by plaintiff groups in these cases concerned the authority of article III courts to execute their orders, ${ }^{277}$ This argument looked directly to the judicial role in maintaining checks and balances in our constitutional scheme. ${ }^{278}$ As the school board plaintiffs in Board of Education of Chicago II stated:

The ability of the Judicial Branch to ensure that lawful judgments against the Executive Branch are enforced is critical to a government of laws and thus the integrity of our constitutional structure. If the Judicial Branch lacks power to enforce judgments voluntarily entered by the Executive Branch .... then the independent and co-equal status of the Judicial Branch is endangered. ${ }^{279}$

Such arguments regarding the necessary reach of judicial power under article III are, of course, the direct counterpart to the government's arguments regarding the necessary constitutional autonomy of the executive under article II. With both sides invoking such broad constitutional claims, these cases seemed very promising vehicles for the elucidation of basic constitutional principles. But things did not turn out that way.

\section{The Decisions}

Despite this extensive discussion of constitutional issues in the briefs, none of the appellate decisions in these cases was explicitly grounded on a constitutional rationale. In the one case in which the plaintiffs clearly prevailed, Ferrell, the appellate court explicitly disavowed the relevance of constitutional considerations. ${ }^{280}$ The other decisions seemed to reflect some degree of judicial sensitivity to the constitutional claims of the executive, but the explicitness of this recognition varied considerably.

275. Brief for Appellees at 48, Adams, supra note 252.

276. Brief for Board of Education of Chicago at 68, Board. of Educ. of Chicago II, supra note 253 (quoting United States v. An Undetermined Quantity, 583 F.2d 942, 949 (7th Cir. 1978) (quoting United States v. United Mine Workers, 330 U.S. 258, 312 (1947))).

277. Plaintiffs have also noted that public policy favors settlement agreements as a means to conserve judicial resources. See, e.g., Brief for National Audubon Society at $48, \mathrm{Na}$ tional Audubon Soc'y, supra note 252.

278. Were the pertinent consent decree void on other grounds, this argument would be irrelevant. The United States has not addressed this issue because it considers consent decree provisions to be unconstitutional to the extent that they divest the executive of authority to exercise discretion.

279. Petition for a Writ of Certiorari at 21, Board of Educ. of Chicago v. United States, 744 F.2d 1300 (7th Cir. 1984), cert. denied, 471 U.S. 1116 (1985).

280. Ferrell v. Pierce, 743 F.2d 454 (7th Cir. 1984). 
The Seventh Circuit's ruling in Board of Education of Chicago $I I,{ }^{281}$ handed down in September 1984, displayed sensitivity to the relevant constitutional distinctions and a marked reluctance to articulate them as such. Throughout its decision, the court seemed anxious to prevent the original consent decree from restricting executive discretion in broad policy matters. It achieved this aim by interpreting the decree in narrow terms. ${ }^{282}$ It held that paragraph 15.1 of the original decreethe agreement to help secure funding for Chicago desegregation efforts-applied only to funds already appropriated. ${ }^{283}$ This interpretation made it unnecessary to question Reagan Administration budget recommendations to Congress and the court accordingly vacated the district court's directives. ${ }^{284}$ The court of appeals also rejected the district court's finding of "bad faith" in the Education Department's "redrafting of administrative regulations limiting grants of Discretionary Funds." 285 The new regulations-despite their restrictive impact on funding for Chicago-reflected "general policy decisions applicable to all grantees" 286 and had not been "drafted specifically to avoid the government's obligations under I 15.1."287 The court left open the possibility that executive lobbying for specific congressional restrictions on funding for Chicago might indeed constitute "bad faith."288 But it chided the district court for responding to the earlier riders "by ordering a \$103.858 million monetary remedy against the government" when "it should have been apparent" that this would have eliminated federal desegregation funding for all other school districts in the country. ${ }^{289}$

On the other hand, the court suggested that the executive might properly be subject to a district court order requiring the government "either to refrain from specific efforts to make desegregation funds unavailable to the board or to inform Congress about the funding obligations of the government under the Decree."290 Moreover, the court of appeals was willing to enforce the ED's "obligation" to give Chicago "top of the list priority" — as the ED was by then promising to do ${ }^{291}$-in

281. 744 F.2d 1300 (7th Cir. 1984).

282. Id. at 1305-06. The Court also relied upon its holding in Board of Educ. of Chicago I that the executive can enter into a contract limiting its discretion in the distribution of congressional appropriations. Id. at 1302-04 (citing Board of Educ. of Chicago I, 717 F.2d 378, 383

(7th Cir. 1983)); see also Devins \& Stedman, supra note 193, at 1274-82.

283. Ferrell, 744 F.2d at 1305-06.

284. The court ruled that, because these policy decisions affected all school districts, the United States did not violate the decree. Id. at 1307 \& n.9.

285. Id. at $1307 \mathrm{n} .10$.

286. $I d$.

287. Id.

288. Id. at 1307-08.

289. Id.

290. Id. at 1308.

291. Id. at 1305-06. The United States had earlier argued that the Board was not entitled to special status. See Brief for the United States at 17-20, United States v. Board of Educ. of Chicago, 717 F.2d 378 (7th Gir. 1983) (No. 82-2308). 
processing grant applications under relevant, general funding programs. Under this ruling, the United States was obligated-for an indefinite period of time-to give the Chicago school board special consideration in ED appropriations decisions. ${ }^{292}$

In Alliance to End Repression, ${ }^{293}$ the Seventh Circuit interpreted the original consent decree so as to avoid interference with the constitutional prerogatives of the executive, although only after an initial decision generally endorsing the district court's injunction. ${ }^{294}$ After a rehearing en banc, the court held that the consent agreement could indeed accommodate the new FBI investigative guidelines. The court of appeals candidly acknowledged that it would "resolve all reasonable doubts in favor of an interpretation of the guidelines that will avoid conflict with the decree." 295 It then proceeded to argue that the district court's literal reading of the consent decree was implausible. Stressing "the consequences of alternative interpretations," 296 the Seventh Circuit concluded that the Justice Department could not have intended to tie "its hands to such an extent; for if it did, it was trifling with the public safety of the people of Chicago and maybe even violating the President's constitutional obligation to 'take Care that the Laws be faithfully executed." "297 The court also stressed the difficulty of limiting the effects of the Chicago consent decree (if read literally) to that one city since "there is no way to keep a Chicago-nurtured terrorist organization in Chicago, any more than the Nazi party could be confined to Munich."298 While affirming the government's obligation to honor many particulars of the consent decree (involving, among other things, regular reporting requirements to the plaintiffs in Alliance to End Repression), the Seventh Circuit preserved the broad discretion of the executive branch over ongoing national policy. ${ }^{299}$

292. The appellate court recently clarified its ruling. See notes 327-329 infra and accompanying text.

293. 742 F.2d 1007 (7th Cir. 1984) (en banc).

294. Id. at 1010-11.

295. Alliance to End Repression, 742 F.2d at 1011.

296. Id. at 1013.

297. Id. at 1014 (quoting U.S. ConST. art. II, $\S 3, \mathrm{cl}$. 3). The appellate court noted that it granted plaintiffs more than a paper victory. Contending that the district court would do little more than slap the FBI's hands if the case had gone to trial, the Alliance court concluded that plaintiffs obtained a fair bargain because "only in Chicago must the FBI report on its investigatory activity periodically to civil rights lawyers." Id. at 1016-17.

298. Id. at 1020. "We doubt that any neutral observer would think it appropriate that the FBI should be governed by other than a uniform national set of investigatory standards ...." Id. at 1018.

299. A due regard for the separation of powers, the flexibility of equity, the ambiguity of the decree, .... the sensitivity and importance of the subject matter, and the limitations of judicial competence argues against precipitating a premature confrontation between the judicial and executive branches in a setting where inevitably some people will say with pardonable exaggeration, that the federal judiciary is playing fast and loose with the public safety.

Id. at 1019. 
In Adams v. Bell, ${ }^{300}$ the District of Columbia Circuit achieved a similar result by questioning the standing of the various plaintiffs involved to maintain such broad-based litigation. In remanding the case to the district court for consideration of the standing issue, the court of appeals noted that the government should generally be "granted the widest latitude in the 'dispatch of its own internal affairs' ":30I "[S]uits challenging the particular programs agencies establish to carry out their legal obligations, rather than specifically identifiable government violations of law are rarely, if ever, appropriate for federal court adjudication." 302

In National Audubon Society ${ }^{303}$ the District of Columbia Circuit offered a still simpler resolution. Taking note of the "novel and farreaching constitutional issues involved," 304 the Court proceeded to reinterpret the original stipulation so as to avoid addressing these issues directly. It held that the original agreement between the National Audubon Society and the Interior Department contained an "implied condition" that the executive's obligation to propose new legislation on the affected water project would lapse after Congress had been given a "reasonable opportunity" to act on its own. ${ }^{305}$ Finding that this condition had been met, the court of appeals concluded that the Interior Department was no longer bound by its earlier agreement and accordingly vacated the district court's injunction against proceeding with the North Dakota water project. ${ }^{306}$

Only in Ferrell $v$. Pierce ${ }^{307}$ did the executive suffer a complete defeat. The Seventh Circuit avowedly ignored, rather than rejected, the constitutional arguments in this case. The Seventh Circuit held that the "difficult constitutional issues" should not be considered because these issues were "never presented, directly or indirectly, to the district

300. 743 F.2d 42 (D.C. Cir. 1984).

301. Id. at 43 (quoting Allen v. Wright, 468 U.S. 737, 761 (1984) (quoting Cafeteria Workers v. McElroy, 367 U.S. 886,896 (1961))).

302. Id. (quoting Allen, 468 U.S. at 759 ).

303. 678 F.2d 299 (D.C. Cir. 1982).

304. Id at $305 \mathrm{n} .12$. Although expressing no opinion on this issue, the Nalional Audubon Soc'y court noted:

General principles may be drawn from dictum in cases dealing with the constitutional prohibition on state law impairing the obligation of contracts, U.S. Const., Art. I, \$ 10; from cases upholding one Administration's decision to change a policy adopted by its predecessors; from cases limiting the power of the judiciary, in the absence of any contract, to direct the Executive in the exercise of its discretion; and from cases holding that particular contracts made by one Administration are binding Id. on its successors.

305. Id at 310 . Underlying this holding was the court's statutory interpretation of the National Environmental Policy Act (NEPA). "Although NEPA may permit the government, in its discretion, to postpone implementation of other federal statutes ... . it certainly does not allow these statutes to be repealed sub silentio at the administrative level." Id.

306. Id. at 311 .

307. 743 F.2d 454 (7th Cir. 1984). 
court." 308 On the merits, the majority endorsed the finding of the district court that the TMAP involved too many disadvantages to be regarded as an "equivalent substitute" for the mortgage assignment program that HUD had originally promised to maintain. ${ }^{309}$ This conclusion was challenged in a forceful dissent that argued that Congress had clearly intended TMAP to supervene the earlier program and charged the majority with attempting to "rewrite our nation's housing laws" and to "engage in social legislation" by "imposing the [court] majority's will for that of Congress." 110 But the majority, on its reading of the TMAP legislation, affirmed the district court's refusal to modify the original consent decree or to release HUD from its requirements. ${ }^{311}$

The appellate decisions in these cases differed considerably in the degree to which they acknowledged the constitutionally protected policy prerogatives of the executive. ${ }^{312}$ In Alliance to End Repression and National Audubon Society, appeals courts interpreted consent decree provisions to favor the government's position so as to avoid constitutional conflicts. The Adams court, while not directly addressing the issue, seemed concerned about the line between judicial authority and executive discretion when it remanded the case on threshold standing grounds. By contrast, the Ferrell court maintained that the government could not raise new constitutional arguments on appeal. Finally, in Board of Education of Chicago II, the court sought to steer an ambiguous middle course. It ruled that the executive may indeed make long-term funding commitments in consent agreements and that courts may enforce such agreements by ordering the executive not to undertake either lobbying activities or administrative policy changes with the specific intention of limiting such funding commitments. On the other hand, the court suggested that such funding commitments should not be allowed to interfere with legislative proposals or administrative policy changes made in good faith with general policy aims.

\section{Critical Assessments: The Price of Hidden Standards}

Courts often avoid ruling on constitutional claims when cases can be

308. Id, at 463. In dicta, however, the court indicated that "we doubt that [this constitutional issue] would be so substantial as to require us to ignore the plain language of the consent decree." Id.

309. Id at $461-63$.

310. Id. at 471 (Coffey, J., dissenting).

311. HUD's implementation of the decree is still subject to a judicial order. Ongoing litigation is now exploring the question of whether HUD activities are consistent with decree requirements. See Ferrell v. Pierce, 785 F.2d 1372 (7th Cir. 1986).

312. In Citizens for a Belter Environment, the D.C. Circuit, although upholding finding for the government, seemed unpersuaded by the intervenors' claim that the executive's discretionary authority is protected by the Constitution. See notes 342-347 infra and accompanying text. The Court emphasized the fit between the consent decree and Congress's generalized purpose in enacting the Clean Water Act, as well as the fact that the EPA had been a party to the decree. Citizens for a Better Env't, 718 F.2d at 1128 . 
resolved on other grounds..$^{313}$ The concerns of the executive prevailed, at least in part, in four of these five cases, even without any direct ruling in favor of the executive's constitutional claims. Still, these cases illustrate the dangers and distortions that can arise when courts seek to evade direct acknowledgement of the constitutional limitations on consent decrees. ${ }^{314}$

The initial posture of all five cases before the appellate courts suggests that the district court judges did not understand these limitations. In each case, the district court judge had entered a consent decree that raised constitutional difficulties. In no case were these questions openly considered when the decree was entered. In each case, district court judges sought to enforce the decrees in circumstances that sharply underscored the constitutional difficulties. But in no case did any of the district judges find a constitutional barrier to upholding the decree or order in question. None of the appellate decisions provides clear guidance to district judges about the potential limits on the authority of district courts to enter or enforce decrees in subsequent cases. ${ }^{315}$

The Seventh Circuit's decision in Ferrell dismissed the constitutional arguments out of hand because they were not directly presented to the district court. This dismissal is confusing because, if there are indeed constitutional limitations on the authority of the executive to sign away its policy discretion in consent agreements, there must be corresponding constitutional limits on the authority of the judiciary to enter or enforce such decrees. ${ }^{316}$ These limitations are not mere technical doctrines in the interest of judicial efficiency, like laches or res judicata, that may be disregarded in appellate proceedings where not pressed in the trial court. These limitations raise fundamental jurisdictional questions about the authority of any federal court under article III. The cavalier dismissal of these questions in Ferrell was an open invitation to district judges to proceed with equal disregard of their jurisdictional limits.

The District of Columbia Circuit behaved much more responsibly in Adams by raising the standing question on its own initiative. Because standing limitations reflect, in part, limitations on judicial authority under article III, ${ }^{317}$ the court of appeals was quite justified in treating

313. See, e.g., Alliance to End Repression, 742 F.2d at 1011; National Audubon Soc'y, 678 F.2d at 306 n.17.

314. Citizens for a Beller Environment also exemplifies the various devices that a court may use to avoid difficult constitutional questions. See notes 342-347 infra and accompanying text.

315. The Supreme Court's recent ruling in Cleveland Firefighters is likely to exacerbate this problem because it encourages the entry of consent decrees without careful judicial scrutiny. See notes $28-37$ supra.

316. See notes 24-27, 265-267 supra.

317. In Warth v. Selden, 422 U.S. 490,498 (1974), the Supreme Court emphasized that standing is a "threshold question in every federal case." See note 177 supra for a brief characterization of the trends in contemporary standing law. See also Brilmayer, The Jurisprudence of Arlicle III: Perspectives on the "Case or Controversy" Requiremenl, 93 Harv. L. Rev. 297, 310-15 
the standing issue as fundamental. Standing limitations are designed to restrict judicial attention to concrete injuries rather than hypothetical issues. ${ }^{318}$ In cases where the plaintiffs' initial claim is a general demand for "appropriate" enforcement of the law, more scrupulous judicial respect for standing limitations might prevent the entry and subsequent enforcement of consent agreements that improperly constrain executive discretion in broad matters of public policy. But standing limitations are notoriously ambiguous and manipulable. ${ }^{319}$ By comparison, limitations on the entry and enforcement of consent decrees derived from article II may be far easier to articulate and apply, and they are no less fundamental.

Adams demonstrates the ambiguity and unreliability of standing limitations. The court of appeals remanded the case for a determination of whether the plaintiffs were properly accorded standing given the complex facts in the case. Despite an elaborate record comprising dozens of proceedings and extending back almost fifteen years, the court of appeals was still unable to determine whether the plaintiffs were properly accorded standing. The court of appeals pointed to the Supreme Court's 1984 decision in Allen $v$. Wright ${ }^{320}$ as particularly calling the standing of the Adams plaintiffs into question. ${ }^{321}$ Allen denied standing to a group of parents of black students alleging lax enforcement by the Internal Revenue Service ("IRS") of nondiscrimination requirements for tax-exempt private schools. This decision may well prove controlling for Adams, but it is still unclear whether Allen represents a broad, reliable precedent in the law of standing. ${ }^{322}$

Thus, for example, in a case closely related to Allen decided only the year before, the Supreme Court raised no threshold justiciability questions about the appropriateness of Bob Jones University to challenge nondiscrimination requirements that the IRS was not even proposing to enforce. ${ }^{323}$ On the other hand, even if the approach to standing in

(1979) (defending standing limitations as an essential limitation of the "case or controversy" requirement in article III).

318. See, e.g., Allen v. Wright, 468 U.S. 737 (1984); Valley Forge Christian College v. Americans United for Separation of Church and State, Inc., 454 U.S. 464 (1981).

319. See Nichol, Rethinking Standing, 72 CALIF. L. REv. $68,68 \mathrm{n} .3$ (1984), for a list of secent commentaries elaborating this complaint. In their complaint, the plaintiffs in Alliance to End Repression alleged that the FBI had conducted illegal surveillance and gathered information about them. 742 F.2d at 1009-10.

320. 468 U.S. 737 (1984).

321. Adams, 743 F.2d at 44 .

322. See id.; cf. Abortion Rights Mobilization v. Regan, 603 F. Supp. 970 (S.D.N.Y. 1985) (holding that Allen does not bar abortion clinics from challenging the tax-exempt status of the Catholic Church), affd, In re United States Catholic Conference, 824 F.2d 156 (2d Cir. 1987). 323. Bob Jones University v. United States, 461 U.S. 574, 585 n.9 (1983). Technically, the standing issue was not raised in Bob Jones University because of a court order prohibiting the IRS from granting tax-exempt status pending the resolution of Allen. Bob Jones University, however, did raise the threshold issue of adverseness. The Administration asked the Court to appoint "counsel adversary" to argue in support of a regulatory scheme that it had once repudiated. See generally McCoy \& Devins, Standing and Adverseness in Challenges of Tax Exemption for Discriminatory Privale Schools, 52 FordHAM L. REv. 441 (1984). Moreover, while adverseness 
Allen is now accorded more respect, Adams might still be distinguished from Allen given the factual differences between the cases. The Adams plaintiffs purport to represent minority, female, and disabled students in institutions regulated by the Office for Civil Rights. The parents in Allen acknowledged that their children did not attend the private schools regulated by the IRS. ${ }^{324}$ Thus, the district court and the District of Columbia Court of Appeals may feel compelled to accept the standing of the Adams plaintiffs after all, and so return to the constitutional difficulties with the consent decree at a later stage. Meanwhile, the Office for Civil Rights must still contend with the constraints imposed by the 1977 decree.

The reinterpretation of decrees to avoid constitutional difficulties, an approach adopted in other cases, also poses considerable problems. In preserving the decree, the courts create uncertainty about the district courts' subsequent enforcement authority. In Board of Education of Chicago II, the Seventh Circuit's interpretation of the decree (as applying only to appropriated funds) allowed the court to vacate the district judge's demand that the president seek additional desegregation funding from Congress for the Chicago schools. But the court of appeals did not provide an explicit ruling on whether the decree would be violated by administration support for particular legislative restrictions on funding available to the Chicago schools. ${ }^{325}$

Given the activist tendencies previously displayed by the district judge in Board of Education of Chicago II, this evasive ruling opened the way for a new round of awkward constitutional confrontations. On remand, the district court interpreted the Seventh Circuit's opinion as requiring the Education Department to give priority treatment to Chicago for all federal programs for which it might be eligible. ${ }^{326}$ In August 1986, the appellate court clarified its earlier ruling and again reversed the district court, holding that while the consent decree operates as a "constraint" on the Secretary's discretion, deference must be given to the Secretary unless his actions "reflect[] an absence of serious consideration of the Board's needs." 327 The appellate court, perhaps tiring of its oversight role in this matter, further suggested that it might be best to vacate the decree. ${ }^{328}$ The court observed: "The history of

is distinct from standing, the two doctrines are closely related. Without adverseness, it is unlikely that the plaintiff actually suffered an injury. That is, how can an agency be sued for the effects of a regulatory scheme that it fails to implement?

324. See Allen v, Wright, 468 U.S. 737,743 (1984).

325. See notes $290-292$ supra and accompanying text.

326. United States v. Board of Educ. of Chicago, 621 F. Supp. 1296, 1396 (N.D. Ill. 1985).

327. United States v. Board of Educ. of Chicago III, 799 F.2d 281, 293-94 (7th Cir. 1986). Specifically, the appellate court required ED to "maximize the amount of funds going to the Board in the same way it would seek to maximize the funds going to any one of a large number of priorities competing for their shares of a limited budget." Id. at 293.

328. Id. at 297 ("the past can and should be undone where ... no amount of funding sufficient to implement the Board's plan at an acceptable level can be provided.") 
this decree is notable not for its success in raising an allegedly segregated school system to a constitutionally acceptable level, but for what it has illuminated about the character and limitations of the executive, municipal and judicial institutions involved."329 In the end, it is quite possible that much fruitless litigation could have been avoided if the Seventh Circuit had faced the constitutional issues directly, ruling clearly from the outset on the impropriety of judicial interference with the executive's legislative recommendations and general policy decisions.

The decisions in Alliance to End Repression and National Audubon Society provide graphic illustrations of a different problem involved in reinterpreting consent decrees to avoid constitutional difficulties. In both cases, appellate courts exercised a highly questionable creativity in their reading of the decrees. In Alliance to End Repression, the Seventh Circuit speculated at length on what would have constituted a reasonable "bargain" for the Justice Department to have struck with the plaintiffs and relied heavily on these speculations without citing any evidence from the actual record in the case to justify its conveniently loose interpretation of the agreement. ${ }^{330}$ In National Audubon Society, the District of Columbia Circuit discovered an "implied condition" in the plaintiffs' agreement with the Interior Department, but did not cite any direct evidence in the record to support this finding. ${ }^{331}$ Both decisions seem to flaunt the Supreme Court's admonition that "the scope of a consent decree must be discerned within its four corners." 332 Both also seem to disregard the principle that district court factfinding should be accorded substantial deference in appellate review. However sympathetic one may be to the immediate policy concerns underlying these creative appellate rulings, the appellate courts went too far in placing their own preferences above the plain language of these "extraordinary" decrees. ${ }^{333}$ Moreover, if applied in more traditional contexts, their rulings would suggest that the government may improperly shirk its legitimate contractual obligations whenever a judge deems it convenient to allow such breaches. ${ }^{334}$

329. Id. at 283.

330. See 742 F.2d at 1023-25 (Cudahy, J., dissenting).

331. 678 F.2d at $3 \mathrm{II}$.

332. United States v. Armour \& Co., 402 U.S. 673, 682 (1971). In National Audubon Society, this concern is heightened because the appeals court could have invalidated the agreement as being inconsistent with the underlying statute. In a concurring opinion, Judge Mackinnon addressed the scope of permissible relief available to environmental plaintiffs under the National Environmental Policy Act (NEPA), 42 U.S.C. \$§ 4321-4370 (1982). He stated that the agreement should have been vacated because plaintiffs, "by indirect means, [have] attempted to enforce a substantive environmental mandate allegedly based on the NEPA that is not authorized by the terms of the law." 678 F.2d at 314 (MacKinnon, J., concurring) (emphasis in original). This approach is quite sound, for it directly confronts the underlying issues of executive and judicial authority on statutory grounds. 333. Alliance to End Repression, 742 F.2d at 1010 .

334. Many of these criticisms can be found in Rademaker, Alliance to End Repression v. City of Chicago: Judicial Abandonment of Consent Decree Principles, 80 Nw. U.L. REv. 1675, 1689. 
To be sure, courts often deliberately choose less plausible legal constructions in order to preserve statutes or other legal instruments from constitutional infirmities. ${ }^{335}$ But this strategy is much less justified when courts fail even to articulate the constitutional obstacles they are trying to avoid. From the standpoint of fairness to the litigants, the approach taken in decisions like Alliance to End Repression and National Audubon Society may actually threaten the "worst of both worlds." On the one hand, these decisions undermine confidence in the impartial enforcement of agreements with the government. On the other hand, by failing to clarify the constitutional limits on such agreements, these decisions do not provide notice to future litigants of which agreements will carry the risk of evisceration by creative construction.

In sum, these cases generally display a disturbing failure to come to grips with the obligations of contracts, the policy prerogatives of the executive under article II, and the limits on judicial power under article III. Faced with serious and novel issues, these courts practiced "issueavoidance" and offered little guidance to lower courts and future prospective parties to consent decrees on the central constitutional questions.

\section{Practical Considerations: The Benefits of EXPLicit STANDARDS}

We have argued that the courts should recognize definite constitutional limits on the enforcement of consent decrees to which the federal government is a party because the Constitution reserves certain policy prerogatives to the independent judgment of the executive. Where courts do not otherwise have the power to preempt executive discretion, they cannot acquire this power, even through the express "consent" of the executive. The executive cannot delegate to the judiciary those constitutional responsibilities entrusted to it any more than it can delegate these responsibilities to private parties.

There is no significant body of case law testing or defining the constitutional limits on the authority of courts to regulate the exercise of executive power because courts rarely issue elaborate direct orders to federal executive agencies over the objections of agency officials. Now the constitutional limits on judicial authority over the executive have finally been placed at issue in the context of consent decrees. But the issue has only now come into focus because agencies commonly negotiate settlement agreements in advance of a judicial judgment on the merits. Even when litigation continues through a judgment on the merits, courts frequently ask executive agencies to negotiate the details

1711 (1986) (student author). This note, however, concludes that the principle of government adherence to contractual obligations outweighs possible separation of powers problems. 335. See, e.g., NLRB y. Catholic Bishop of Chicago, 440 U.S. 490, 507 (1979). 
of the remedial orders. ${ }^{336}$ By shifting responsibility for the content of decrees back to the executive-or allowing the executive to take this responsibility on its own shoulders-courts may imagine that they are displaying more respect for the separation of powers or allowing more scope for administrative expertise. But the consent of executive offcials to particular orders cannot save the decrees from constitutional difficulties. And at a practical level, such consent may compound the potential for abuse.

The absence of clearly articulated and acknowledged limitations on the permissible scope of government consent decrees, and on the authority of courts to enter and enforce such decrees, invites abuse on several levels. First, this absence invites federal agencies to placate particular parties at the expense of their broader policy responsibilities to the general public. Second, it invites federal agencies to evade proper accountability by securing a judicial imprimatur for their own disputable policy choices. Finally, it threatens democratic accountability in a different way by allowing one administration to bind its successors. Each of these dangers can be illustrated by some of the cases we have already examined.

\section{A. Placating Particular Parties}

In the Chicago school board case, the Carter Administration negotiated a rather remarkable settlement agreement. Having previously demanded more encompassing plans to reassign students in the Chicago school system, the Carter Justice Department agreed to a different approach and promised to help secure federal financing for the new plan. The timing of this settlement (September 1980) strongly suggests that the Carter Administration was anxious to end its longstanding dispute with Chicago officials in advance of the 1980 presidential elections, ${ }^{337}$ Whatever the merits of that desegregation agreement as a particular instance of civil rights policy, the agreement had the effect of mortgaging a large share of Education Department funds that might have been better spent elsewhere in an era of general spending constraints. Such distortions in the allocation of government resources are inevitable, however, if there are no limits to what agencies may promise in their eagerness to settle particular cases.

This misallocation can be even greater when the government, as a defendant, is tempted to settle suits brought by public interest plaintiffs that directly concern large national policies. That is, of course, what happened in Ferrell $v$. Pierce, where HUD mortgaged its future flexibility

336. See, e.g., American Pub. Health Ass'n v. Veneman, 349 F. Supp. 1311 (D.D.C. 1972) (district court issued elaborate findings of inadequate enforcement by FDA and then simply appealed to the parties for help in constructing a remedial order).

337. For a critical account of the circumstances of this settlement that hints at political

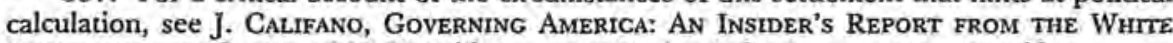
HOUSE AND THE CABINET 228-29 (1981); see also Devins \& Stedman, supra note 193. 
in the administration of a complex housing program by agreeing to a particular set of standards to settle a suit brought by a handful of private program beneficiaries. ${ }^{338}$ The government, like any defendant, always faces time and resource pressures to settle cases rather than continue with long and costly litigation. These pressures cannot be avoided and voluntary settlement is, no doubt, often a desirable and efficient mode of resolving legal disputes. But in suits involving broad questions of public policy, there may also be peculiar political pressures to settle quickly and avoid prolonged controversy or bad publicity. ${ }^{339}$ In such cases, it is peculiarly important to set limits on what the executive may bargain away, lest public policy be permanently fixed by shortterm political expediencies.

\section{B. Evasion of Policy Responsibilities}

One difficulty with freezing the policy decisions made at a particular moment is that government officials cannot always anticipate future needs or circumstances at the time decrees are negotiated. But shortsightedness is not the only risk involved in overly broad consent agreements. What must also be balanced against the interest in securing quick and amicable settlements is the public interest in maintaining accountable government. As they constrain policy discretion, legal commitments may also reduce political responsibility for government officials: What is required by consent agreement or court orders need not be otherwise justified or rethought by agency officials. Thus the government may not challenge or resist an improper decree even in later years when its constraints become more burdensome.

In truth, "the government" is a legal abstraction. In the real world, a variety of officials in different agencies at different levels of authority are engaged in continuous pulling and hauling over resources, priorities, and subtle gradations of policy. A consent decree can be an all too ready handle for officials at one level to manipulate their superiors or rivals - with consequent distortions to the ongoing development of policy. ${ }^{340}$ In the Adams v. Bell litigation, for example, officials of the Office for Civil Rights pleaded the demands of the consent agreement to forestall scrutiny and reformist pressures from successive department secretaries, while department secretaries used the litigation to cajole larger appropriation requests from the Office of Management and Budget. ${ }^{341}$

The risks in such inside dealing are starkly illustrated by the 1983

338. See notes $240-247$ supra and accompanying text.

339. On the general tendency to avoid controversy in regulatory decisionmaking, see The Politics of Regulation 375-78 (J.Q. Wilson ed. 1980).

340. For a brief discussion of the pressure on agency leaders to conciliate subordinates,

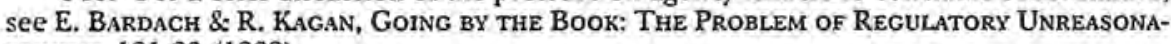
BLENESS 181-83 (1982).

341. See Perspectives on Current Developments, REg., Mar.-Apr. 1981, at 5. 
decision of the District of Columbia Circuit in Citizens for a Better Environment. ${ }^{342}$ In 1976, the EPA negotiated a consent agreement with a number of environmental groups in a suit challenging the agency's failure to implement provisions of the Clean Water Act within mandated statutory deadlines. ${ }^{343}$ The agreement pledged the agency to adopt certain scientific methodologies and decisionmaking criteria in determining whether to issue additional regulations and in determining whether other pollutants should be included in the regulatory scheme. But the agreement also allowed the agency further extensions of time in which to act. The settlement was eventually challenged, not by the Reagan Administration, but by steel companies, which protested that the decisionmaking criteria and procedures involved were not required by the statute and would predetermine the results in a manner prejudicial to their interests.

The court of appeals ultimately upheld this agreement as a fair "balancing of the equities," although the court conceded that the procedures involved were not mandated by the statute and might have been designed otherwise. ${ }^{344}$ In rejecting the claim of these industry-intervenors, the court maintained that its holding did not impinge on the agency's discretion to determine the ultimate substance of the regulation. Instead, the court claimed, its holding only "requires EPA to begin the process of formulating regulations ... and describes a methodology to be followed by the agency." 345 This attempted distinction between substance and "methodology" is not at all persuasive, however, as Judge Wilkey pointed out in a powerful dissenting opinion, and as the Supreme Court has suggested in other cases. ${ }^{346}$ By resorting to this highly dubious distinction, the court of appeals managed to obscure the very serious constitutional problems with the consent decree in Citizens for a Better Environment.

The most notable feature of the case, however, was the position of the government. Because the EPA was still comfortable with the agreement, Justice Department attorneys argued that the agency must remain bound by it $^{347}$ despite contrary arguments advanced by the Justice Department in the cases described above! The EPA could cer-

342. 718 F.2d 1117 (D.C. Cir. 1983).

343. See Natural Resources Defense Council v. Train, 8 Env't. Rep. (BNA) 2120 (D.D.C. 1976), modified, Natural Resources Defense Council v. Costle, 12 Env't. Rep. (BNA) 1833 (D.D.C. 1979).

344. Citizens for a Beller Env'l, 718 F.2d at 1125.

345. Id.

346. "The consent decree commits the EPA Administrator to certain choices-choices as to priorities, choices as to methods, choices as to allocation of resources." Id. at 1133 (Wilkey, J., dissenting). For a parallel insistence on the substantive implications of courtordered procedural requirements, see Vermont Yankee Nuclear Power Corp. v. Natural Resources Defense Council, 435 U.S. 519 (1978).

347. The decree was characterized by the Justice Department as "an accomodation to EPA's discretion" rather than an intrusion on EPA's authority. Brief for Federal Appellees at 40, Citizens, supra note 252. 
tainly have adopted the decisionmaking procedures and criteria involved in the free exercise of its discretion, as the majority opinion acknowledged. But the Reagan appointees at EPA found it far more convenient to hide behind the constraints of the consent agreement than to make this decision on their own authority.

Allen $v$. Wright also illustrates these dangers. The plaintiffs sought to force the Internal Revenue Service ("IRS") to impose more demanding nondiscrimination requirements on tax-exempt private schools. The Reagan Administration eventually succeeded before the Supreme Court in its challenge to the plaintiffs' standing. ${ }^{348}$ But in 1978, the IRS had sought to satisfy the plaintiffs by proposing new regulations imposing elaborate affirmative action requirements on private schools. ${ }^{349}$ These regulations provoked so much protest and controversy that Congress voted riders to the IRS appropriation in 1979 (and in ensuing years), denying the IRS any funds to enforce these proposed new requirements. ${ }^{350}$ Had the IRS negotiated the substance of these regulations in a consent agreement with the plaintiffs, however, instead of issuing them on its own authority, it might well have evaded public and congressional accountability on the matter. The legislative history of the appropriation riders makes it clear that Congress was quite reluctant to interfere with already existing judicially sanctioned decrees. ${ }^{351}$

\section{Shortcircuiting Electoral Accountability}

Excessive diffusion of authority and consequent vulnerability to special interest pressures are endemic problems in American government. $^{352}$ The Supreme Court has frowned on direct delegation to private parties of governmental standard-setting powers. ${ }^{353}$ But at least since the $1930 \mathrm{~s}$, political scientists have charged that, in one policy sphere after another, federal authority has been unduly influenced by organized special interests. ${ }^{354}$ The public interest law movement of the 1970 s was greatly inspired by this critique. And the broadening of access to the courts for public interest challenges was largely inspired by the desire of federal courts-as well as Congress-to provide a new forum to challenge agency favoritism toward special interests. ${ }^{355}$ But

348. Allen v. Wright, 468 U.S. 737 (1984).

349. 43 Fed. Reg. 37,296 (1978), revised at 44 Fed. Reg. 9,451 (1979).

350. Treasury, Postal Service, and General Government Appropriations Act of 1980 , Pub. L. No. 96-74, $\$ \S 103,614,93$ Stat. 559, 562, 576 (1979).

351. See, e.g., 125 Cong. Rec. S11, 979-80 (daily ed. Sept. 6, 1979) (statement of Senator Helms, claiming that these riders would "not change the existing law").

352. J.M. Burns, The Deadlock of Democracy: Four-Party Politics in America (1963) is the most famous of numerous critiques along this line. For a more recent version, see Cutler, To Form a Govemmenl, Foreign AfFairs, Fall 1980, at 126.

353. See notes 110-113 supra and accompanying text.

354. One of the most powerful and influential contemporary statements of this perspective is T. Lowi, The End of Liberalism: Ideology, Policy, and the Crisis of Public AUTHORITY (1969).

355. For an early defense of public interest litigation as an antidote to the "capture" of 
public interest groups, however well-meaning or sincere, may frequently be captivated by highly partisan or highly parochial perspectives on public policy. ${ }^{356}$ Without clear limits on the extent to which they may tie down agency policies with consent decrees, public interest groups may simply present a new version of the problem they were expected to remedy: the delegation of public policymaking authority to private interests.

There is, of course, no easy escape from the problem of special interest pressures in public policy. The Constitution does not create a simple system of majority rule, but a complex system of checks and balances in which several differently constituted bodies all have an equal claim to speak for the majority. The complexity of the system obviously enhances the bargaining power of marginal constituencies. ${ }^{357}$ Nonetheless, public policy cannot be sensibly governed by an endless scramble among particular, narrow interests, if for no other reason than that this sort of scramble is likely to prove self-defeating for most of the interests involved. As recent experience with tax reform suggests, particular interests that strain too hard to secure particular advantages may frustrate wider benefits which they themselves might otherwise enjoy. ${ }^{358}$ And wider public interests are likely to be more persistently advanced by political representatives with a broader political base. The president, elected from a far broader voting base than any other elected official, is often better situated to speak for the broadest public concerns. ${ }^{359}$

Yet, just as government consent decrees can undermine the policy responsibility of executive officials by making policy choices appear uncontrollable, these consent decrees can also sever this essential link between particular policies and the broad signals conveyed by the electorate in presidential elections. Thus, the defeat of President Carter in 1980 was widely interpreted as a sign of public exasperation with excessive federal spending and with heavy-handed, overly intru-

regulatory agencies by "special interests," see Lazarus \& Onek, The Regulators and The People, 57 VA. L. REV. 1069 (1971).

356. See, for example, M. Douglas \& A. Wildavsky, Risk and Culture: AN Essay on THE Selection of Technical and EnVIRonmental Dangers 164-73 (1982) for a characterization of the "sectarian" outlook of safety and environmental public interest groups.

357. As Louis Jaffe noted more than twenty years ago, it is not always easy to distinguish " "special interests' fairly defeated by the political process" from " 'minorities' whose claims to equality are being run over rough-shod by ... conniving majorities. ..." L. JAFFE, JUDICial Control of Administrative Action 489 (1965). Madison warned that a popular majority could easily "sacrifice to its ruling passion or interest both the public good and the rights of other citizens," and accordingly denounced "a pure democracy" as "admit[ting] of no cure for the mischiefs of faction." THE FEDERALIST No. 10, at 56-60 (J. Madison) (C. Rossiter ed. 1961).

358. For an elaboration of this theme, see A. MAAss, Congress AND the Common Good (1983),

359. R. Neustadt, Presidential Power: The Politics of Leadership (1960). 
sive federal regulation. ${ }^{360}$ But the consent decrees in Ferrell and Board of Education of Chicago II reduced the Reagan Administration's capacity to limit spending as the Adams decree reduced the Administration's capacity to limit regulatory intrusiveness.

This constraint on the executive is not a problem solely for administrations claiming a mandate to constrain big government. ${ }^{361}$ President Carter's first Secretary of Health, Education and Welfare, Joseph Califano, sharply criticized the Adams decree for hampering his capacity to revitalize OCR through the rearrangement of enforcement priorities and resources within the agency. ${ }^{362}$ More generally, an administration committed to a range of major new spending and regulatory initiatives might be most resentful of having its hands tied by awkward, competing commitments. ${ }^{363}$

In the larger scheme of things, the effect of any particular consent decree may seem trivial. But a great many policy decisions can be shrugged off on the grounds that no single one makes much difference. And this complacency is really the heart of the problem with consent decrees that commit the government to general policies: They reinforce the bureaucratic tendency toward inertia, toward uncritical acceptance of established policy, ${ }^{364}$ Elections are supposed to counter that tendency, and constitutional principles are supposed to remind government officials that even small decisions may implicate large concerns. ${ }^{365}$ The principle that executive policy must remain open to the

360. Kiewiet \& Rivers, The Economic Basis of Reagan's Appeal, in The New DIREction IN American Politics 69, 70-71 (J. Chubb \& P. Peterson eds. 1985).

361. President Carter's 1976 election arguably benefitted from his asserted concern about civil rights issues. For an account of the 1976 presidential election stressing the importance to candidate Carter of very high support from black voters along with a willingness by white voters to put aside opposition to busing, see Weissberg. The Democratic Party and the Conflict Over Racial Policy, in Do Elections MAtTER? 204-20 (B. Ginsberg \& A. Stone eds. 1986).

362. J. Califano, supra note 337, at 218-19.

363. See, e.g., DeMuth \& Ginsburg, White House Review of Agency Rulemaking, 99 HARv. L. REv. 1075, 1082 (1986) (emphasizing that even a White House committed to extending regulatory controls in certain areas would seek to maintain centralized executive oversight in order to determine priorities). Rules and policies determined in litigation are, however, exempted from review and approval by the Office of Information and Regulatory Affairs in the Office of Management and Budget, the principal coordinating mechanism at present. For a contrasting perspective, see Rosenberg, Beyond the Limits of Executive Power: Presidential Control of Agency Rulemaking Under Execulive Order 12,291, 80 MrCH. L. REv. 193 (1981) (arguing that Order 12,291 violates the separation of powers because the Administrative Procedures Act, 5 U.S.C.A. $\$ \$ 551-59,701-06$ (West 1977), gives plenary informal rulemaking authority to administrative agencies). 119.

364. On the perils of legalistic inertia, see E. BARDACH \& R. KAGAN, supra note 340 , at 93 .

365. The "Court is the institution best fitted to give us a rule of principle, which we strive to attain along with the principle of self-rule. Hence principle, called constitutional law, is in the Court's charge, and the other institutions are expected to defer to the Court with respect to it. Anything else would probably not work." A. Bickel, The Least Dangerous BRANCH 261 (2d ed. 1986). 
influence of new elections does not invoke a concern that is fanciful or purely rhetorical.

\section{SUMMARY AND CONCLUSION}

Several recent cases in the courts of appeals have raised-without clearly settling - a major constitutional issue: How far may the federal government bind its policy discretion in consent agreements? Even if consent agreements are regarded as contracts, it does not follow that they must always be honored. In cases dealing with ordinary government contracts, the Supreme Court has continually held that government may not bargain away essential sovereign powers or obligate itself as readily as private parties. ${ }^{366}$ To the extent that consent decrees are regarded as judicially sanctioned remedies rather than mere contracts between the parties, ${ }^{367}$ the argument for limitations remains equally compelling. There must be limits on the extent to which courts may preempt the policy discretion vested by the Constitution in the executive branch. Otherwise, the separation of powers would have no meaning. The limits that courts must respect on their own remedial authority cannot be extended by the temporary acquiescence of the executive. 368

Three areas of discretion constitutionally reserved to the executive suggest three limitations on what is constitutionally permissible in the entry and enforcement of consent decrees. First, the Constitution reserves for the president an unrestricted discretion to make (or to withhold) legislative and budgetary recommendations to Congress in accord with presidential views of the public interest. If courts could limit this discretion (or allow the executive to consent to have it limited), then an essential element in the system of checks and balances devised by the Framers could be curtailed by litigation. ${ }^{369}$

Two other limitations relate to implementing discretion within the executive branch. Courts, we contend, must not interfere with the discretion of executive officers in establishing broad spending priorities nor with discretion in setting broad enforcement priorities. Consent agreements that unduly constrain such discretion must be considered unenforceable. Otherwise, courts could not only threaten the authority of the executive to adjust administrative priorities to new circumstances-including a new political mandate from the voters-but also threaten the authority of Congress to influence administrative priorities

366. See notes 48-66 supra and accompanying text.

367. See notes 21-26 supra and accompanying text.

368. See notes 82-99 supra and accompanying text.

369. "The Constitution sought to divide the delegated powers of the new Federal Government into three defined categories, Legislative, Executive and Judicial, to assure, as nearly as possible, that each branch of government would confine itself to its assigned responsibility." INS v. Chadha, 462 U.S. 919, 951 (1983). 
by varying the scale of annual appropriations. ${ }^{370}$

Failure to acknowledge these limitations creates considerable hazards for private litigants, for the judiciary, and for the executive. In the first place, there is the prospect of uncertainty and unfairness for litigants because judges may interpret away agreements upon which the litigants once thought they could rely. ${ }^{371}$ On the other hand, administrative officials may use consent agreements with outside parties to insulate their policies and priorities from appropriate political controls. Both prospects could be substantially reduced if courts forthrightly acknowledged the relevant limitations on their own remedial authority and on the permissible scope of consent agreements.

The argument for preserving executive discretion presupposes, of course, that the executive does have lawful discretion in the particular case. Executive agencies usually have such discretion in the implementation of broad statutory programs. But even then, the discretion accorded by statutes is rarely of the all-or-nothing kind; statutes generally limit executive choices regarding implementation policy, while leaving some range of choice within these limits for the executive on how and when to act. ${ }^{372}$ How, then, can courts prevent executive agencies from making unlawful choices without constraining legitimate discretion? Or, to state the problem from the standpoint of a would-be plaintiff, how can there ever be a successful challenge to the adequacy of implementation if the courts will not direct or sanction a particular course of action for the agency involved?

There is admittedly some awkwardness in allowing challenges to agency policies when a "successful" challenge can secure nothing more than a directive to the agency to offer a different alternative. It is tedious, if not faintly ridiculous, for a reviewing court to remand new policies back to an agency, time after time, with the conscientiously selflimiting advice from the court that "what you have done (or omitted to do) is not acceptable under the statute but we won't tell you what you must do." It seems much quicker and easier for the court to ratify whatever agreement seems mutually satisfactory to the agency and its particular challengers in the initial round of litigation.

That it seems unfairly burdensome to would-be plaintiffs to deny this expedient is perhaps a serious argument against opening courts, in the first place, to challenges that do not invoke clearly defined personal rights with clear and direct remedies. ${ }^{373}$ But if we continue to allow

370. For a forthright statement of the need for "economic" assessments of the "worth" of enforcement, implying that appropriations are a means of gauging proper levels of "investment" in enforcement, see Easterbrook, Foreword: The Court and the Economic System, 98 HaRv. L. REv. 4, 41-42 (1985).

371. See notes $330-333$ supra and accompanying text.

372. For a concise statement of this view, see L. Jaffe, Judicial Control of AdminisTRATIVE ACtION 181 (1965).

373. For elaboration of the argument that standing ought to be confined to clear private 
[Vol. 40:203

public interest challenges to broad agency policies, this burden on the challengers may simply be the necessary price they-and the judges and the executive officials involved-must pay for a system that opens so many questions of executive discretion to judicial review. As the Supreme Court observed in Chadha, "[I]t is crystal clear [that] the Framers ranked other values higher than efficiency." 374

And in the larger scheme of things, the preservation of executive discretion is not at odds with the cause of good government. Rather, our constitutional scheme presupposes that "energy in the executive is a leading character in the definition of good government" and sound administration. ${ }^{375}$ This constitutional presumption should not be overturned to satisfy the convenience of judges, private plaintiffs, or executive officials.

rights, see Scalia, The Doctrine of Standing as an Essential Element of the Separalion of Powers, 17 SUFFOLK U.L. REv. 881 (1983).

374. 462 U.S. at $958-59$.

375. "Energy in the executive ... is not less essential to the steady administration of the laws" than to "the protection of the community against foreign attacks ...." THE FederaLIST No. 70, at 423 (Rossiter ed. 1961). 